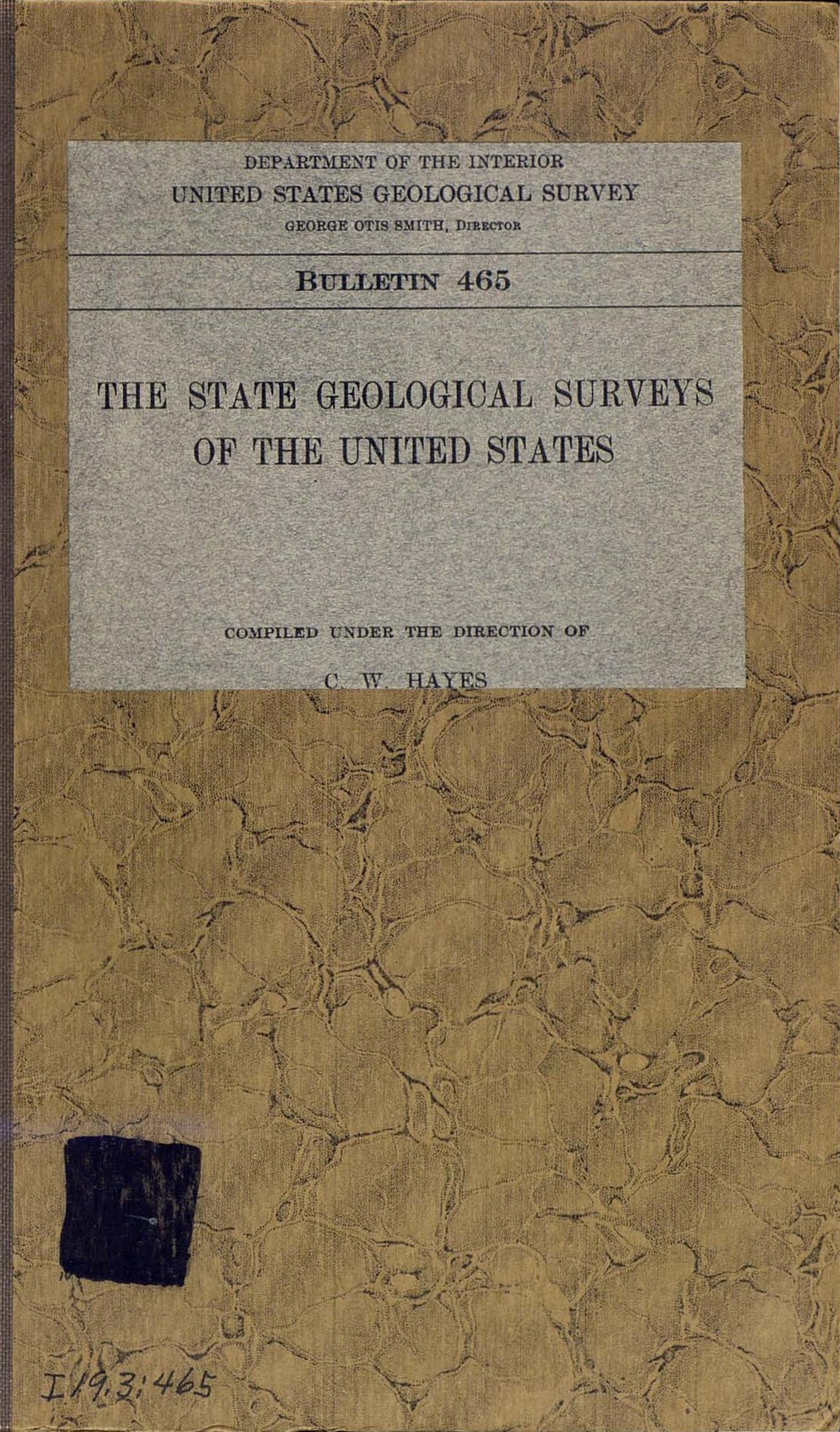


TEXAS TECH UNIVERSITY

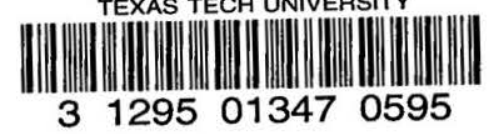


DEPARTMENT OF THE INTERIOR

UNITED STATES GEOLOGICAL SURVEY

GEORGE OTIS SMITH, DIRECTOR

BuLlitin 465

\section{THE STATE GEOLOGICAL SURVEYS OF THE UNITED STATES}

COMPILED UNDER THE DIRECTION OF

C. W. HAYES

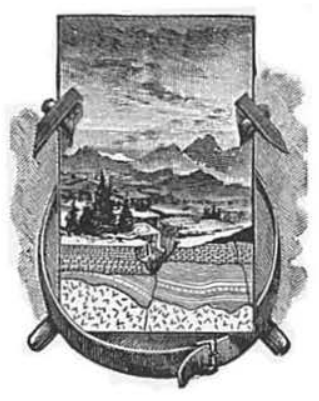

W ASHINGTON

GOVERNMENT PRINTING OFFICE

1911

LIBRARY

TEXAS TECHNOLOGICAL COLLEGE

LUBBOCK, TEXAS 



\section{O N T E T T.}

Introduction Page.

Alabama

Arizona

Arkansas__. 17

California_-_-_- 20

Colorado

Connecticut-_- 29

Florida___-

Georgia_-_-_-_- 36

Illinois__-_-

Indiana

Iowa_-_- 53

Kansas-_- 59

Maine

Maryland_-_. 69

Michigan

Minnesota_._.......... 80

Mississippi_-_._- 82

Missouri-_-_-_. 86

Nebraska_-_-_. 89

New Jersey

New York

North Carolina_-_._. 101

North Dakota

Ohio

Oklahoma__-_. 116

Pennsylvania_._.

Rhode Island_-_. 130

South Carolina

Tennessee-_._- 138

Vermont_-..-.....-_. 142

Virginia_-

Washington-_._- 149

West Virginia_-_._-_._-_-_- 153

Wisconsin

Appendix

Internal Improvement Commission of Illinois_-_-_-_-_- 167

Territorial engineer of New Mexico

New York State Water Supply Commission 



\title{
THE STATE GEOLOGICAL SURVEYS OF THE UNITED STATES.
}

\author{
Compiled under the direction of C. W. HaYes.
}

\section{INTRODUCTION.}

Information concerning State geological surveys is difficult or impossible to obtain. Much of it is scattered through many publications, and many facts regarding organization and methods are not published. Such information is in constant demand by cooperating State and Federal organizations, by persons interested in the organization of new State surveys, and by the State geologists themselves. It is the last named to whom the information is of greatest value, for many common problems of administration are met by all State geologists, and a statement of the successful solution of a problem by one will help others to solve the same problem. This need of accurate information was urgently expressed by the geologists and engineers in attendance at a conference held in Washington in the spring of 1910, and as a result of rather full discussion a committee was appointed to take charge of the matter. It seemed to the committee that the end in view could be best attained by requesting the heads of the several surveys to prepare statements regarding their organizations. Accordingly the following circular letter and outline were submitted to all State geologists and to all State engineers and other officials having cooperative relations with the Federal Survey.

Trenton, N. J., July 15, 1910.

DEAR S18: At the conference of the officials of the United States Geological Survey and the State geologists and heads of other cooperating bureaus held in Washington May 31-June 1, a committee was appointed to collect and compile information regarding the organization and work of the various surveys with a view to its early publication as a handbook of geological and hydrographic surveys in the United States. As all present at the conference seemed to wish the plan carried out, it is hoped that those absent will also find it attractive and will assist in its preparation.

In order that the statements may be accurate and comprehensive, it is desired that they be carefully prepared for publication by some official of the respective surveys, and that the subsequent work of compiling and editing be reduced to a minimum. To this end please follow as closely as possible the following out- 
line, giving in narrative form explicit information on as many of the points mentioned as are applicable to your survey or bureau.

In order that the bulletin may be issued with reasonable promptness, please prepare and forward the data without delay to Dr. C. W. Hayes, United States Geological Survey, Washington, D. C.

Yours truly,

H. B. KÜMmex, New Jersey,

C. W. HAYES, United States Geological Survey,

F. W. DE WoLF, Illinois,

W. McCulnoH, New York,

Committce.

OUTLINE.

1. Give a brief résumé ( 600 to 800 words) of previous geological surveys or of autecedent scientific bureaus in your State, of which your bureau is the outgrowth, giving specifically the name of each, date, scope of work and accomplishments, and causes of discontinuance.

2. Give the exact name of the present survey or bureau and date of its organization.

3. Give a summary of the laws governing your survey which are now operative.

4. If not already given under 3, outline the organization of your survey under the following heads:

(a) Governing board. Name, number of persons, method of appointment, terms of office, compensation (if any) as members of this board (not salaries if they serve ex officio).

(b) Executive officer. Title, name of individual; method of appointment, date of appointment of present incumbent, term of office. If an ex officio appointment or other State or educational position is held, please state; give proportion of time spent on survey. work. Indicate whether compensation is per diem or by regular monthly or annual salary; how fixed, whether by law or by rule of governing board.

(c) Subordinates. Group your subordinates into three classes-(1) clerical; (2) geologic, including chemical and technologic; (3) topographic, including engineering and hydrographic. For each of these classes give the approximate number of each class employed, their method of appointment (by the managing board, executive head, with or without intervention of civil-service commission, etc.), term of service, per diem or permanent, range of pay for different classes. It is particularly desired to know to what extent advanced college students or college professors are employed on surveys.

5. Appropriations. A. Please state how your appropriations are made, whether continuing, annual, biennial, or for any stated period. Are any contingent upon cooperation?

B. Do unexpended balances carry to a new fiscal year or do they lapse to the treasury? If the latter, how soon after the close of the year?

C. Give your annual appropriation, specifying objects, if so fixed by law.

D. Estimate in percentages the average expenditure under the following heads :

(a) Administrative and routine clerical; include only such part of the salary of the head of the survey and of others as may be charged to administrative work.

(b) Topographic, including field work and office work (not administrative). 
(c) Economic, stratigraphic, and areal geology, including office work in preparation of reports.

(d) Statistical geology.

(e) Paleontologic geology as distinct from stratigraphic.

(f) Chemical work.

(g) Underground water resources.

(h) Drainage surveys.

(i) Stream flow and reservoir surveys.

$(j)$ Testing road materials or other highway work, not including construction.

(k) Highway construction.

(l) Other technologic work.

$(m)$ Other lines of work or combinations which can not be included under above heads, specifying nature of work.

6. Publications. A. Enumerate the various series of reports, bulletins, monographs, and maps published, giving the $(a)$ number of volumes of each series so far issued, $(b)$ size of editions, $(c)$ method of distribution (if sold, give average annual income and its disposition-whether paid to State treasury, etc.).

B. Average annual cost of printing reports and accompanying maps for last five years or by volumes. Does this come from your Survey appropriation or from some other fund?

C. Do you have full control over printing your maps and reports, as to choice of printer, style of report, paper, illustrations, etc., contents of report? If not, state explicitly the nature of the limitations.

D. Do you have full control over distribution of your reports? What classes of persons and institutions are on your mailing list and how is it kept alive?

7. Present main lines of work, (1) by your bureau independently; (2) in cooperation (state nature and extent of cooperative work): $(a)$ With the United States Geological Survey, $(b)$ with geological surveys of other States, $(c)$ with other bureaus of the National Government, $(d)$ with other scientific bureaus of your own State.

It was hoped that by means of the above outline a fair degree of uniformity of treatment would be secured, and this hope has been in a measure realized. Necessarily some editing has been required, but this has been confined so far as possible to matters of form, arrangement, headings, etc. The delay in transmitting the material to press has been due to delay of the authors in furnishing it, although a number of requests of increasing urgency were sent to several of the delinquents.

It was originally intended that the bulletin should include all State organizations which cooperated with the United States Geological Survey in geology, topography, or hydrography, but only a few of the State officers other than the State geologists have complied with the request for a statement, and it has been decided to bring these together in an appendix, rather than in the body of the bulletin with the geological surveys, with which they are not readily comparable.

Thirty-six States recognize geologic work as a necessary and proper governmental function and have organizations for the carrying on of such work. The complete list of States and Territories 
with names of organizations and names and titles of executive officers follows:

Alabama.-Geological Survey of Alabama; E. A. Smith, State geologist, University.

Arizona.-Geological Survey of Arizona; C. F. Tolman, Territorial geologist, Tucson.

Arkansas.-Geological Survey of Arkansas; A. H. Purdue, State geologist, Fayetteville.

California.-California State Mining Bureau; L. E. Aubury, State mineralogist, San Francisco.

Colorado.-Colorado State Geological Survey; R. D. George, State geologist, Boulder.

Connecticut.-State Geological and Natural History Survey; William North Rice, superintendent, Middletown.

Delaware.-Maintained Geological Survey of State of Delaware, 1837-1838. Florida.-Florida State Geological Survey; E. H. Sellards, State geologist, Tallahassee.

Georgia.-Geological Survey of Georgia; S. W. McCallie, State geologist, Atlanta.

Illinois.-State Geological Survey; F. W. DeWolf, director, Urbana.

Indiana.-Department of Geology and Natural Resources; Edward Barrett, State geologist, Indianapolis.

Iowa.-Iowa Geological Survey; Samuel Calvin, State geologist, Iowa City.

Kansas.-State Geological Survey of Kansas; Erasmus Haworth, State geologist, Lawrence.

Kentucky.-Kentucky Geological Survey; C. J. Norwood, director, Lexington. Louisiana.-Maintained Geological Survey in connection with the State Agricultural Experiment Station, 1891-1909.

Maine.-State Survey Commission; C. Vey Holman, State geologist, Bangor.

Maryland.-State Geological and Economic Survey; William Bullock Clark, State geologist, Baltimore.

Massachusetts.-Maintained Geological Survey of Massachusetts, 1830-1841. Michigan.--Michigan Geological and Biological Survey; R. C. Allen, State geologist, Lansing.

Minnesota.-Maintained Geological and Natural History Survey, 1872-1900.

Mississippi.-Geologic, Economic, and Topographic Survey of Mississippi;

E. N. Lowe, director of the State Geological Survey, Jackson.

Missouri.-Bureau of Geology and Mines; H. A. Buehler, director and State geologist, Rolla.

Nebraska.-Nebraska Geological Survey; Edwin H. Barbour, State geologist, Lincoln.

Nevada.-Maintained office of State mineralogist, 1866-1878.

New Hampshire.-Maintained Geological and Mineralogical Survey, 18401844 ; $1868-1878$.

New Jersey.-Geological Survey of New Jersey; Henry B. Kümmel, State geologist, Trenton.

New York.-Science Division (Geological Survey) of the Educational Department; John M. Clarke, State geologist and paleontologist, State Museum, Albany.

North Carolina.-North Carolina Geological and Economic Survey; Joseph Hyde Pratt, State geologist, Chapel Hill.

North Dakota.-North Dakota Geological Survey; Arthur Gray Leonard, State geologist, Grand Forks. 
Ohio.-Geological Survey of Ohio; J. A. Bownocker, State geologist, Columbus. Oklahoma-Oklahoma Geological Survey; Charles N. Gould, director, Norman. Oregon.-Maintained office of State geologist, 1872-1874.

Pennsylvania.--Topographic and Geological Survey Commission; Richard R. Hice, State geologist, Beaver.

Rhode Island.-Natural Resources Survey of Rhode Island; Charles W. Brown, superintendent, Providence.

South Carolina.-South Carolina Geological Survey; Earle Sloan, State geologist, Charleston.

South Dakota.-Geological Survey of South Dakota; E. C. Perisho, State geologist, Vermilion.

Tennessee.-Tennessee State Geological Survey; George H. Ashley, State geologist, Nashville.

Texas.-Maintained office of State geologist at various times from 1858-1S92; University of Texas Mineral Survey, 1901-1904.

Vermont.-Geological Survey of Vermont, G. H. Perkins, State geologist, Burlington.

Virginia.-State Geological Survey of Virginia; Thomas Leonard Watson, director, Charlottesville.

Washington.-State Geological Survey of the State of Washington; Henry Landes, State geologist, Seattle.

West Virginia.-West Virginia Geological and Economic Survey; I. C. White, State geologist, Morgantown.

Wisconsin.-Wisconsin Geological and Natural History Survey; E. A. Birge, superintendent and director, Madison.

Wyoming.-Geological Survey of Wyoming; C. E. Jamison, State geologist, Cheyenne.

Idaho, Montana, New Mexico, and Utah have had no State surveys.

\section{ALABAMA.}

\section{PREVIOUS SURVEYS.}

The first step toward the systematic study of the geology of Alabama was taken in 1847 by the University of Alabama, when, on the appointment of Prof. Michael Tuomey to the professorship of geology of that institution, it was stipulated that each year a part of his time should be spent in geologic explorations in the State. In accordance with this arrangement he immediately began field studies, publishing in the newspapers of Tuscaloosa such extracts from his reports as might be of general interest. In recognition of this effort the State legislature, in January, 1848, appointed Prof. Tuomey State geologist, without salary, and requested him to make to that body a report of his work for publication by the State. Thus was begun the first geological survey of Alabama.

In 1849 Prof. Tuomey presented to the legislature his first report, which was published in 1850 by the State. The geologic map, however, appeared later.

Prof. Tuomey continued his explorations at the expense of the University of Alabama from 1848 to 1853. In 1854 the legislature 
of Alabama passed an act to provide for a Geological and Agricultural Survey of the State. The sum of $\$ 2,500$ was appropriated annually for the salary of the State geologist, and the further sum of $\$ 10,000$ was appropriated to employ assistants and defray the expenses incidental to the office. The governor was authorized to appoint a State geologist, who during the period of his service should hold no other office in the State. The governor was also authorized to fill by appointment a vacancy in the office of State geologist should one occur before the completion of the survey. In other sections of this act the duties of the State geologist were defined.

Under this act Prof. Tuomey was appointed State geologist, and until his death in 1857 he devoted practically his whole time to the duties of the office. His headquarters were at the University of Alabama, where he occasionally delivered courses of lectures.

Prof. Tuomey's second report was submitted to the legislature in 1855 , but was not published until after his death, although the legislature in February, 1856, ordered the printing of 3,000 copies. In April, 1857, immediately after the death of Prof. Tuomey, Dr. John W. Mallet was commissioned by Governor Winston to supervise the printing of the report. This report was published in 1858, together with the second geologic map of the State. In these two reports, with accompanying maps, the geologic subdivisions of Alabama were defined, and the future importance of the coal and iron deposits of the State were foreshadowed.

After the death of Prof. Tuomey the civil war and reconstruction problems overshadowed all other subjects, and no geologic work was carried on by the State until 1873. During this period, however, a commissioner of industrial resources was one of the regular officers. of the State, and four short reports, embracing perhaps 20 or 30 pages each, were issued from that office between 1869 and 1874.

In 1871 the University of Alabama, upon its reorganization, again took the lead in geologic investigations by authorizing the professor of geology in that institution, Prof. E. A. Smith, the present State geologist, to spend a part of his time in geologic field work

\section{PRESENT SURVEY.}

LEGAL DESIGNATION AND DATE OF ORGANIZATION.

"Geological Survey of Alabama" is the designation employed in the codes since 1873, when the present Survey was organized.

\section{HISTORICAL SKETCH.}

In 1873 the legislature passed an act "to revive and complete the Geological and Agricultural Survey of Alabama," appointed Prof. E. A. Smith, the present incumbent, State geologist, and appropri- 
ated $\$ 3,000$ for equipment and $\$ 500$ a year for a period of 10 years for the expenses of the Survey, the State geologist to receive no salary from the State, his only compensation being that paid by the University for his services as a professor in that institution.

These conditions continued for the next 10 years, during which time the greater part of the State was visited and a number of reports were made, dealing mainly with the coal and iron resources and the agricultural features of the State. For most of this time Prof. Smith had the assistance of Henry McCalley, who also gave his services gratuitously to the Survey.

In 1883 the legislature increased the annual appropriation to $\$ 5,000$ and in 1891 to $\$ 7,500$. This made possible more effective work. Acting under it, Mr. McCalley was given general charge of investigations in the Warrior coal field and of the iron interests; Joseph Squire and A. M. Gibson were placed in charge of investigations in the Cahaba and Coosa coal fields, respectively; and Prof. Smith took charge of investigations in the metamorphic area and of studies of the Coastal Plain deposits.

Reports on all these regions were prepared and published in due course of time. Reports on the gold deposits were prepared by Dr. William B. Phillips, W. M. Brewer, and others. Dr. Phillips also prepared a report on iron making in Alabama, which quickly ran through two editions, and a proposed third edition is now in preparation. From Dr. Heinrich Ries was obtained a report on the clays of the State. The water resources were also investigated, and preliminary reports on the water powers and on the artesian and other underground waters of the State have been published. In the preparation of the water reports the United States Geological Survey cooperated; also in the preparation of the preliminary report on the Coastal Plain, the first outline of which was published as Bulletin 43 of the United States Geological Survey, under the joint authorship of E. A. Smith and L. C. Johnson.

In 1896 a geologic map of the State was published, with explanatory chart embodying all the information accumulated up to that time.

From the outset the ideal of the Survey has been to take account of all the State's natural resources-mineral, geologic, agricultural, and biologic. Through the liberality of T. H. Aldrich a bulletin on Tertiary fossils was issued in 1886, and under an arrangement with C. L. Herrick a partial report on the fresh-water and marine Crustacea of the State was published in 1888. Mr. Aldrich also contributed a preliminary list of the fresh-water mollusks of the State, which was published in the report for 1876. Material has been gradually accumulated, through donations and the collections of the Survey workers, for an account of various other forms of animal life native to Alabama, which may be published in due course of time. 
A small preliminary iist of the plants native to Alabama was published many years ago by Dr. Charles Mohr and Prof. E. A. Smith, and a monumental work on the plant life of Alabama was prepared by $\mathrm{Dr}$. Mohr and published in 1901 in cooperation with the United States Department of Agriculture. It was the intention that Dr. Mohr should prepare another volume on the timbers and other plants, either useful or noxious, but his death interfered. This work was assigned to Dr. R.・M. Harper, and the first installment of a report on the timber trees of the State is now in manuscript awaiting publication.

\section{SUMMARY OF LAWS.}

The functions of the Survey, as defined in the 1906 Code of Alabama, are as follows:

SEc. 689. State geologist.-Eugene A. Smith, professor of mineralogy and geology in the University of Alabama, is State geologist. In the event of a vacancy in the office of State geologist, from any cause, the professor of geology in the University of Alabama shall be ex officio State geologist.

SEc. 690. His duties.-It shall be the duty of the State geologist to devote such portions of his time as may not be required for the discharge of his duties as a professor in the University of Alabama to making exploration and examination of the mineral, agricultural, and other natural resources of the State, so as to determine accurately the quality and character of its soils and their adaptation to agricultural purposes, and especially to the occurrence and quality of phosphates, marls, gypsum, and other natural fertilizers; its mineral resources and their location, character, and capacity for development; its water powers and their capacities; jts forest trees and their utilities and distribution; and it shall be the duty of him and his assistants, whenever they discover any valuable deposits of iron or other ore, coal, phosphates, marls, or other substances of value, to notify immediately the owners of the land upon which such deposits occur. He shall make to the legislature quadrennially a report of the progress of his explorations and examinations, together with analyses of soils, ores, minerals, and mineral waters, with maps, charts, and drawings, which report shall be printed and shall be the exclusive property of the State. He shall also make collections of specimens and illustrations of the geological and agricultural resources of the State, one of which shall be deposited in the cabinet of the University of Alabama, a second in the cabinet of the Alabama Polytechnic Institute, and a third in the office of the commissioner of agriculture and industries in the capitol at Montgomery.

SEc. 691. Assistants.-The State geologist shall have power to appoint, with the approval of the governor, such assistants, including a competent chemist, and for such periods and with such compensation as he may deem necessary to the best interests of the Survey.

SEc. 692. Annual appropriation.-There is appropriated, out of any funds in the treasury not otherwise appropriated, fon the Geological and Agricultural Survey provided for in this chapter, annually, the sum of $\$ 7,500$. Upon the requisition of the State geologist, when approved by the governor, the auditor shall draw his warrant on the treasurer for the amount appropriated, in such sums as may be needed from time to time for the purposes of the Survey herein provided for; and for all expenditures made under the provisions of this chapter, except for the payment of the salary of the State geologist, the 
approval of the governor must be obtained, and the vouchers of the State geologist for all such expenditures must be filed with the auditor and a statement of his receipts and expenditures shall accompany each quadrennial report of the State geologist.

SEc. 693. Salary.-The State geologist shall receive out of the State treasury a salary of $\$ 100$ a month as State geologist during the time he shall be engaged in performing his duties as professor of mineralogy and geology in and is paid a full professor's salary by the University of Alabama; and when not so employed and paid by the said university, he shall receive a salary of $\$ 200$ a month, out of the State,treasury, payable as other State oflicers' salaries are paid.

SEc. 694. Expense of Survey.-The balance of the annual appropriation herein provided for shall be devoted, so far as may be necessary to execute the purposes of this chapter, to the discharge of the expenses of the Survey, including the compensation of all temporary and permanent assistants; traveling expenses of the geologist and the geological corps in and out of the State; purchase of apparatus and material for making chemical analyses; other necessary expenditures for outfit; expenses incurred in providing for the transportation, arrangement, and proper exhibition of the geological and other collections made under authority of this chapter, and the engraving of maps and sections to illustrate the quadrennial reports of progress.

SEc. 695. Bulletins of State geologist.-Whenever the State geologist has in hand, ready for publication, material for a bulletin or any other report of his surveys and investigations of the mineral, agricultural, or other natural resources of the State, he shall report the same to the governor, and a committee consisting of the governor, secretary of state, and State geologist shall then determine the number of such bulletin or report which shall be printed and published.

SEc. 696. Printing and binding geological bulletins.-When the number of such bulletin or report to be printed or published has been so determined, the governor shall order the same to be printed and bound forthwith at such times and places, and in such manner and style as regards size, type, quality of paper, binding, etc., as said committee may deem best, and in similar manner he shall have engraved and printed all charts, maps, views, drawings, sketches, or details as may be deemed necessary by said committee to properly illustrate such bulletin or report. And for the purposes herein mentioned, when, in the opinion of said committee, the State printers are not prepared to do in proper manner any engraving or other work required for such report or bulletin, the governor may make special contracts with such persons, firms, or corporations, within or without the State, as in the judgment of said committee will secure the promptest and most satisfactory work.

SEc. 697. Payment for printing and binding bulletins.-The accounts for the printing, engraving, and binding done under the provisions of this chapter when approved by the governor, shall be paid by his order out of any moneys in the State Treasury.

\section{ORGANIZATION.}

The form of organization of the Survey is described in the foregoing code of laws.

There is no governing board, except that expenditures, aside from those of a routine nature, are first authorized by the governor, and for the reports and bulletins the governor, secretary of state, and 
State geologist constitute a committee which decides as to the style of printing, illustrations, and binding, the size of the edition, and the firm or firms to which the work shall be assigned.

The executive officer of the Survey is the State geologist. Prof. Eugene A. Smith has held the office since his appointment by the legislature in 1873, when the Survey was revived. The term of office is not limited. The appointee must be the professor of geology in the State University. His duties and compensation are specified in the foregoing code of laws.

At present the assistants include a chief assistant, a chemist, a curator of the museum, a field assistant, and a stenographer. Temporary assistants for special work are employed as occasion arises. All employees are appointed, and their compensation is fixed by the State geologist with the consent of the governor. Professors and advanced students are occasionally employed.

\section{APPROPRIATIONS.}

The appropriations for the Survey are made annually, the sum of $\$ 7,500$ being each year set aside for the purpose.

There are no unexpended balances, the money being drawn from the State treasury before the end of the fiscal year and placed in bank subject to check for payment of obligations incurred but not fully discharged before the end of the fiscal year.

Specific information as to allotments is not available. In a general way it may be said that the money has been expended chiefly in the preparation of reports of an economic nature, requiring, however, as a matter of course, more or less areal and stratigraphic work. The only paleontologic publication is a bulletin on Tertiary fossils, which, however, was contributed by T. H. Aldrich, who also bore the expense of printing. A partial report on the fresh-water and marine Crustacea of the State, prepared through the cooperation of C. L. Herrick, has also been issued, as well as a preliminary list of the fresh-water mollusks of the State, the latter contributed by $\mathrm{Mr}$. Aldrich. One volume is devoted to underground waters and another to water powers. The former involved many chemical analyses. Two editions of a technologic report on iron making in Alabama have been exhausted and a third edition is in hand. A bulletin on road materials and highway work is in preparation.

\section{PUBLICATIONS.}

The publications of the Geological Survey of Alabama comprise a series of annual progress reports from 1874 to 1882, inclusive; a series of bulletins, numbered 1 to 9 , inclusive; and 19 other special reports. These publications cover a wide range of subjects, but are chiefly 
of an economic nature, though stratigraphic, areal, and paleontologic geology are represented. Many of the reports relate to special areas; others are of a more general character. The plant life of Alabama and the trees, water supplies, and water powers of the State are also included in the list of subjects studied. Preliminary reports on the fresh-water and marine Crustacea of the State and on the freshwater mollusks have also been published, while a technologic report on iron making in Alabama has run through two editions and a third edition is about to be issued.

The usual edition is 2,500 copies, although of some reports editions of 5,000 and 10,000 copies have been printed.

The governor, the secretary of state, and the State geologist constitute the committee on printing. Under the law, in case the State printers are not prepared to prosecute in proper manner the printing and engraving of a report, "the governor may make special contracts with such persons, firms, or corporations, within or without the State, as in the judgment of said committee will secure the promptest and most satisfactory work."

Publications are distributed free of charge (except one, the price of which is $\$ 1$ plus 16 cents for postage), but applicants are required to pay the postage. The distribution is in charge of the State geologist. The mailing list includes a number of public libraries in Alabama and other States, all geological surveys in the United States and many foreign surveys, and geologists of America and other countries. The mailing list is kept alive by sending out notices of new publications, with request to forward postage in case the report is desired. Special notices inquiring whether the person addressed desires to be retained on the list are also sent out from time to time.

The cost of printing and engraving is paid out of the State treasury and does not fall upon the Survey appropriation. The cost of printing, binding, and illustrating 17 of the reports ranged from $\$ 140$ to $\$ 8,201$. The size of these reports varied from 79 to 862 pages. The cost of printing during the last 35 years has averaged about $\$ 1,000$ annually. The amount received from the sale of publications may aggregate $\$ 1,000$. Part of this has been expended to meet Survey expenses and the remainder is in bank awaiting the decision of the attorney general as to its proper disposition

PRESENT LINES OF WORK.

INDEPENDENT INVESTIGATIONS.

Investigations of the region of igneous and metamorphic rocks are in progress, and a map of the Coosa coal field is in preparation. From the outset the Survey has given consideration to all the natural resources of the State-mineral, geologic, agricultural, and biologic. 
Data regarding the plants native to the State have been accumulated from the beginning of the Survey. Material has also gradually been collected for an account of the forms of animal life native to Alabama.

Manuscripts awaiting publication include the third edition of the report on iron making in Alabama, a report on the timber trees and other woody plants of Alabama, a report, with map, of the Cahaba coal field, and a bulletin on the road materials and highways of the State.

\section{COOPERATIVE INVESTIGATIONS.}

United States Geological Survey.-The mapping of a part of Fayette County, embracing the territory where gas wells have been brought in, is in progress in cooperation with the United States Geological Survey. Each Survey is to expend $\$ 1,000$ on this work. A joint study of the deposits of the Alabama coastal plain is also being made. Statistics of the mineral production of Alabama are collected in cooperation with the Federal Survey.

Other departments of the National Government.-Statistics of the public highways of Alabama are collected in cooperation with the United States Department of Agriculture. "The plant life of Alabama," by Dr. Charles Mohr, issued in 1901, was also published in cooperation with that department.

Other State geological surveys.-While no definite plans have been formulated for cooperation with other State surveys, a close correspondence is maintained with the State geologists of South Carolina, Georgia, Florida, and Mississippi, and from time to time joint trips are made with the heads of these surveys, with the view to coordination of work.

Other scientific bureaus of the State.-There is no active cooperation with other scientific bureaus of the State. Under the law duplicates of collections made in Alabama by the Geological Survey are deposited with the Alabama Polytechnic Institute and the State commissioner of agriculture and industries. Surplus duplicates in the collections are distributed among the most important high schools of the State, other State institutions, and scientific societies, with the view to building up branch museums in different parts of the State.

\section{ARIZONA.}

The office of Territorial geologist of Arizona has been held successively by John F. Blandy, Theodore B. Comstock, W. P. Blake (recently deceased), and C. F. Tolman. The office has been considered an honorary one, and in recent years no funds have been available for the work, although in 1909 a small apportionment for expenses was made. 
The reports of the Territorial geologists have consisted of brief statements, published at irregular intervals, in the reports of the governor to the Secretary of the Interior at Washington, D. C. Dr. Blake's latest report appeared under the title "Minerals of Arizona, their occurrence and association."

The forthcoming report of the Territorial geologist will contain a geologic map of Arizona, as well as a bibliography of Arizona geology and allied subjects. A surnmary of the salient features of the geology of Arizona's mineral deposits is also in preparation.

\section{ARKANSAS.}

\section{PREVIOUS SURVEYS.}

\section{OWEN SURVEY. ${ }^{a}$}

The subject of a State Geological Survey of Arkansas was first brought to public attention by Governor Elias N. Conway in his message to the legislature in 1856. On his recommendation the matter was taken into consideration, and the first Geological Survey of the State was begun under an act passed January 4, 1857. This act provided for the appointment of a State geologist by the governor, and an appropriation of $\$ 4,800$ per annum, out of which all expenses were to be paid. Dr. David Dale Owen, then State geologist of Kentucky, was appointed State Geologist of Arkansas, and entered upon his duties October 1,1857 . The results of the work done in 1857 and 1858 are given in Owen's "First report of a geological reconnoissance of the northern counties of Arkansas," Little Rock, 1858.

The bill providing for the continuation of the Survey passed in February, 1859 ; by its provisions the State geologist's salary was raised from $\$ 1,800$ to $\$ 2,500$, and an appropriation of $\$ 6,000$ per annum was made for the Survey work. Under this act Dr. Owen was again appointed State geologist. Before the next legislature convened Dr. Owen died (November 13, 1860) and his "Second report of a geological reconnoissance" was edited by his brother, Dr. Richard Owen and Prof. J. P. Lesley, and was printed at Philadelphia in 1860.

The civil war broke out shortly after the publication of Dr. Owen's second report, and all such work was necessarily suspended in the Southern States. No steps were taken to finish the geological survey of Arkansas until after the close of the war.

\section{RECONSTRUCTION SURVEYS. ${ }^{a}$}

In the general assembly of 1866 a bill was passed by the senate providing for a Geological Survey of the State, but it was rejected by the lower house.

In the legislature of 1871 a survey bill was passed (and approved March 28, 1871) appropriating $\$ 15,000$ for two years' work. Under this act Governor o. A. Hadley appointed W. F. Roberts, sr., of Pennsylvania, State geologist.

a Branner, J. C., Jour. Geology, vol. 2, No. 8, 1894, pp. 826-836.

$85645^{\circ}-$ Bull. $465-11-2$ 
The records in the office of the secretary of state do not show how long Mr. Roberts held office, but he was appointed June 5, 1871.

Dr. George Haddock, then of Arkadelphia, was, upon Governor Hadley's recommendation, appointed Mr. Roberts's assistant, and went with him through the western part of the State.

Mr. Roberts's report was never delivered to the governor. ****A series of articles, however, was subsequently published by Mr. Roberts in the Age of Steel, of St. Louis, Mo. (1887-88), and it is probable that these articles represent his views of the geology of the State and give the results of his work. They are largely a repetition of the results given by Dr. Owen.

In 1873 Dr. George Haddock, who had been Mr. Roberts's assistant, published at Little Rock a pamphlet of 66 pages, entitled "Report of a geological reconnoissance of a part of the State of Arkansas made during the years 1871-72." This paper gives the only results of the work done under this appropriation. It is of but little or no importance and adds nothing to the work done by Dr. Owen.

The general assembly of 1873 passed a bill for the continuation of the survey, and made an appropriation of $\$ 15,000$ for it.

Under this act the following State geologists were appointed: George Haddock, appointed May 15, 1873, removed from office January 14, 1874. Mr. Haddock * * * made no report except the one published under a former appropriation and mentioned above. William C. Hazeldine, appointed January 14,1874 , and removed June $29,1874 . *^{*} *$ As State geologist he made no report, and, so far as can be ascertained, did no field work. Arnold Syberg was appointed June 29, 1874, and remained in office to the end of the term. $*^{*} *$ Mr. Syberg $*^{*} *$ made no report, and $*^{*} *$ the only work he did was to receive and examine specimens sent or brought in from various parts of the State.

The failure of the surveys for years 1868 to 1875 to yield any geological results must be attributed to the general demoralization of the State government during the reconstruction period.

No further efforts were made to carry on a geological survey until the year 1881, when a bill for such work was defeated in both branches of the general assembly.

In the assembly of 1883 the only legislation passed relating to geological work was a senate concurrent resolution "authorizing and directing the governor to make application to the Secretary of the Interior of the United States for a geological survey of the State of Arkansas." Nothing seems to have come of this effort to obtain help from the National Government.

\section{BRANNER SURVEY.}

In January, 1887, Governor Simon P. Hughes, in his message to the general assembly, suggested an appropriation for a Geological Survey. An act was accordingly passed providing for the appointment of a. State geologist and three assistants. Under this act Dr. J. C. Branner was appointed State geologist and entered upon the duties of the office June 24, 1887.

In the general assembly of 1889 there was much opposition to the continuance of the Survey, "due chiefly to the fact that the Survey had declared fraudulent certain so-called gold mines in the western 
part of the State." The bill, however, passed, and Dr. Branner was reappointed State geologist. The Survey was continued by the general assembly of 1891, with the understanding that it should be brought to a close by the end of March, 1893. However, the general assembly of 1893 appropriated $\$ 4,000$ to complete the publication of reports: During Dr. Branner's term of office a large number of reports were issued. The annual report for 1888 comprised four volumes, that of 1889 . two volumes, 1891 two volumes, 1892 five volumes, and two reports remain unpublished for lack of appropriations. The reports issued are chiefly of an economic nature, although a few are of a more general geologic character.

\section{PRESENT SURVEY.}

LEGAL DESIGNATION AND DATE OF ORGANIZATION.

The present organization is entitled the Geological Survey of Arkansas; it was established in 1907.

\section{ORGANIZATION AND SUMMARY OF LAWS.}

The Survey is in charge of a commission, known as the geological commission of Arkansas, and composed of the governor of the State, the president of the University of Arkansas, and the commissioner of mines, manufactures, and agriculture. The members of the commission receive no compensation for services rendered for the Survey, but are reimbursed for actually necessary expenses.

The title of the executive officer is State geologist of Arkansas. The professor of geology in the University of Arkansas is ex officio State geologist. The position is now filled by Prof. A. H. Purdue, who devotes about 15 per cent of his time to Survey work. The compensation, which is per diem, is fixed by the commission.

The assistants include one geologic aid, six engineering aids, and one clerk. The assistants are appointed by the State geologist, subject to the approval of the commission. To the present time they have all been professors or advanced students of the University of Arkansas.

\section{APPROPRIATIONS.}

Appropriations are made biennially and are partly contingent on cooperation with the United States Geological Survey. Unexpended balances carry to the next fiscal year.

The amount of the appropriation varies. The act of 1907 appropriated $\$ 1,800$ "for a geological survey of the slate deposits in Arkansas in cooperation with the United States Geological Survey." The act of 1909 appropriated $\$ 5,000$ for the purpose of carrying on 
the work of the Survey. The money is expended in about the following proportions:

Administrative and routine clerical work
Economic, stratigraphic, and areal geology, etc
Investigation of stream flow, etc-
Other technologic work

Appropriations for the next biennial period have not yet been made, but as this bulletin goes to press it is learned that the senate of the general assembly has passed a bill with but one dissenting vote appropriating $\$ 7,500$ for $1911-12$.

\section{PUBLICATIONS.}

Three reports have been issued by the present Geological Survey of Arkansas. One is on the slates of the State, another is on coal mining in the State, and the third is a preliminary report on the water, powers.

The average annual cost of printing reports and maps for the last four years has been $\$ 1,300$. This is paid from the State printing fund.

The State geologist has full control of the printing, except the choice of printer. Printing is done by contract with the State printing board.

The State geologist has control of the distribution of the reports, except that by law each member of the legislature receives 10 copies. The mailing list is composed of State educational institutions and other educational institutions of prominence, State geologists, State geological surveys, geologists, and the leading libraries of the country.

\section{PRESENT LINES OF WORK.}

Independent field work.-An investigation of the clay deposits of the State is in progress, with the view of ascertaining the extent of each deposit and the purposes to which it is best suited, also an investigation of coal mining in the State, for the purpose of conserving the coal deposits and improving the coal-mining industry.

Cooperation with United States Geological Survey.-In cooperation with the Federal Survey the water powers of the State are being studied.

\section{CALTFORNIA.}

\section{PREVIOUS SURVEYS.}

The California State legislature in 1860 enacted a law providing for the appointment of a State geologist and appointed Prof. J. D. Whitney to the position. His duty, as set forth in the law, was defined as follows:

With the aid of such assistants as he may appoint, to make an accurate and complete geological survey of the State and to furnish in his report of the same 
proper maps and diagrams thereof, with a full and scientific description of its rocks, fossils, soils, and minerals, and of its botanical and zoologicil productions, together with specimens of the same, which specimens shall be properly labeled and arranged and deposited in such place as shall be hereafter provided for that purpose by the legislature.

Prof. Whitney, as State geologist, appointed Prof. W. H. Brewer principal assisant in charge of the botanical department and William Ashburner assistant in geologic field work. The party assembled in San Francisco in November, 1860, and soon began field work. The first year of reconnoissance was devoted almost exclusively to the Coast Ranges, but subsequently other portions of the State were visited. Connected with the Survey originally were C. Averill and C. J. Hoffman, topographic assistants; Dr. J. G. Cooper, zoologist; W. M. Gabb, paleontologist; Prof. Brush, of the Sheffield Scientific School, who made an examination of ores; and Clarence King, a volunteer assistant in the reconnoissance of the high Sierra.

Four years later the California legislature enacted a law to continue the Survey and again appointed Prof. Whitney to the position of State geologist. In token of appreciation of the work performed the salary of the State geologist was increased from $\$ 6,000$ to $\$ 9,000$ per annum.

Several years later the legislature suspended the work of the Survey, but the publication of the reports of the State geologist and his assistants continued for a time. Among the volumes issued were "The Yosemite guide book," "Contributions to barometric hypsometry," "Report on the fossil plants of the auriferous gravel deposits of the Sierra Nevada," "The climatic changes of later geological times," "Detailed description of the Mount Diablo coal fields," "Examination of the bituminous substances occurring in southern California," "Report on an examination of the quicksilver mines of California," and "Chemical examination of Pacific coast coals."

\section{PRESENT SURVEY.}

LEGAL DESIGNATION AND DATE OF ORGANIZATION.

The present organization is entitled the California State Mining Bureau; it was established by an act approved April 16, 1880.

Under this act the following have served as State mineralogist: Henry G. Hanks, 1880 to 1886 ; Wm. Irelan, 1886 to 1893 ; J. J. Crawford, 1893 to 1897 ; A. S. Cooper, 1897 to 1901 ; L. E. Aubury, 1901 to the present time.

\section{SUMMARY OF LAWS AND ORGANIZATION.}

The law governing the Bureau provides-

(1) For the maintenance of a principal office in San Francisco, under the supervision of the board of trustees, numbering five, all of whom must be residents and citizens of the State. 
(2) That the trustees shall hold office four years from the date of their appointment and shall have control of all properties and funds of the Bureau.

(3) That the governor shall appoint the State mineralogist, who must have a practical knowledge of mining and mineralogy and who shall hold office for the term of four years from the date of his appointment.

(4) That the duties of the State mineralogist shall include the collection of statistics regarding the economically important minerals; the making of a collection of typical geologic and mineralogical specimens to constitute the museum of the State Mining Bureau; the assembling of a library of books, reports, and drawings bearing upon the mineral industries, the sciences of mineralogy and geology; the collection of models, drawings, and descriptions of the appliances used in mining and metallurgical work; and the issuance of biennial reports, setting forth the important results of the work, and such bulletins as he may deem advisable concerning the statistics and technology of the mining industries of the State.

The trustees serve without salary; the State mineralogist receives a salary of $\$ 250$ a month.

The present State mineralogist is L. E. Aubury. The employees of the State Mining Bureau include a secretary and curator of the museum, a geologist, a librarian, a statistician and assistants, clerical help, and field assistants. The number of the latter varies from time to time. All the subordinates are appointed by the State mineralogist. They are employed by the month. The salaries range from $\$ 85$ to $\$ 150$ a month.

\section{APPROPRIATIONS.}

Appropriations are made by the State legislature biennially. No appropriation is made contingent upon cooperation. Unexpended balances lapse to the State treasury about 60 days after the close of the fiscal year. There is no fixed appropriation; the amounts vary. The appropriations provide for salaries, field work, current expenses of the Bureau, and the maintenance of the museum, library, and geologic and statistical departments.

\section{PUBLICATIONS.}

The publications issued by the California State Mining Bureau number 58. They include the first and third biennial reports (numbered XI and XIII, respectively); a series of 18 bulletins; the register of mines, with maps, of 17 counties; the register of oil wells. with map, of one county; 10 maps showing boundaries of national forests; and 8 other special maps, of certain districts. Aside from 
the maps, the publications are wholly of an economic character and relate entirely to the minerals of the State.

The size of the edition varies according to the estimated demand, but the average is about 2,500 copies.

The method of distribution is provided for by the following law:

The board [board of trustees] is hereby empowered to fix a price upon, and to dispose of to the public, at such prices, any and all publications of the Bureau, including reports, bulletins, maps, registers, etc. The sum derived from such disposition must be accounted for and used as a revolving printing and publishing fund for other reports, bulletins, maps, registers, etc. The prices fixed must approximate the actual cost of printing and issuing the respective reports, bulletins, maps, registers, etc., without reference to the cost of obtaining aud preparing the information embraced therein.

All publications of the Bureau are issued from the press of the State printer at Sacramento.

The State mineralogist dictates the style, matter, paper, and contents of the publications. The Bureau distributes its own publications. Some of them are sold at a nominal price. Purely statistical works are distributed free at the office of the Bureau; when they are mailed postage is charged. The mailing list includes newspapers, magazines, and interested persons. The list is kept alive by exchanges; these include technical journals, the daily press, etc.

PRESENT LINES OF WORK.

General scope.-The California State Mining Bureau is, as its name implies, devoted primarily to the interests of the miners and the producers of minerals in California. Its principal lines of work consist of the preparation of publications. dealing with both general and special investigations of the mining industry. In connection therewith it maintains, in a permanent museum, a large collection of minerals and mining appliances, also a library made up of mining and allied publications, maps, etc. It annually collects and disseminates, in a series of bulletins, mining statistics. It endeavors to prevent discrimination against the products of the State whenever public moneys are to be expended for the construction of buildings or other purposes.

Cocperation with United States Geological Survey.-The Bureau cooperates to a certain extent with the United States Geological Survey, from which statistics relating to the production of precious metals in California are received. These are made a part of the statistical reports issued by the State Mining Bureau, and due credit is given to the Federal Survey for its agency in the matter.

Other cooperative investigations.-Cooperation of the Bureau with technical or other societies is not obligatory, but the policy of the trustees is liberal in this direction, and assistance is often given. 


\section{Colorado.}

\section{PREVIOUS SURVEYS.}

The office of State geologist of Colorado was created by act of the Territorial legislature in 1872 , under which the governor of the State was authorized "to appoint, by and with the advice of the senate, a State geologist $* * *$ to hold office for a period of two years." This seems to show an early appreciation of the needs of the State; but another clause of the same act reads as follows: "No compensation for services, nor for any expense whatever, shall be paid by the State to or for said State geologist."

So far as the available records show, the first State geologist was J. Alden Smith, who was appointed in 1874. The law provided that the State geologist should hold office until his successor was appointed. This may account for certain irregularities in the dates of appointments. In $1881 \mathrm{Mr}$. Smith was again chosen. From that time until the organization of the State Geological Survey, in 1907, the appointments were as follows: 1883, Ernest Le Neve Foster, Georgetown; 1885, J. Alden Smith, Denver; 1887, Fred G. Buckley, Leadville; 1889, 1893, Geo. E. Kedzie, Ouray; 1897, 1899, Thomas A. Rickard, Denver; 1901, 1903, John W. Finch, Victor; 1906, B. A. Langridge, Boulder.

As will be seen by the above list, some very able men have filled the office of State geologist, but the failure of the State to provide funds for the work prevented them from accomplishing much. Three or four brief reports were published, but these were long since out of print.

\section{PRESENT SURVEY.}

LEGAL DESIGNATION AND DATE OF ORGANIZATION.

The present organization is entitled the Colorado State Geological Survey; it was organized April 24, 1907, under a law of 1907, which was amended in 1909.

SUMMARY OF LAWS.

The law establishing the Survey, enacted in 1907, as amended in 1909, is as follows:

SEcrion 1. There is hereby created and established a State Geological Surrey, which shall be under the direction of an advisory board, composed of the governor of the State, who shall be êx officio chairman, the president of the University of Colorado, the president of the State School of Mines, and the president of the State Agricultural College. The advisory board shall confer with the State geologist in all matters pertaining to the aims and objects, and to the conduct of the work of the Survey. Said board shall receive no compensation, but the members shall be reimbursed for expenses actually incurred in the performance of their official duties. 
Sec. 2. The said Survey shall have for its objects :

(1) A study of the geological formations of the State with special reference to its economic mineral resources, namely, the gold, silver, lead, copper, iron, and other metallic ores; the clays, coals, oil, gas, building materials, artesian and mineral waters, and other mineral substances.

(2) An examination of the topography and physical features of the State with reference to their practical bearing upon the occupations of the people.

(3) Such cooperation with the State Bureau of Mines as shall be mutually beneficial.

(4) The preparation and publication from time to time of geologic, economic maps to illustrate the mineral resources of the State.

(5) The preparation and publication of special reports, with necessary illustrations and maps, which shall give both the general and detailed description of the geology and natural resources of the State.

(6) The preparation and publication of a comprehensive summary or digest, together with a complete bibliography and maps, of all the trustworthy literature and reports heretofore published on the geology and mineral resources of Colorado.

(7) The preparation of a series of bulletins on the geology, geography, and natural resources of Colorado, suitable for use in the high schools of the State.

(8) The consideration of such other scientific and economic subjects and questions as in the judgment of the advisory board shall be deemed of value to the people of the State.

SEc. 3. The field investigation, preparation of reports and maps, and all the executive functions of the Survey shall be under the personal supervision of the head professor of geology in the University of Colorado, who shall also be State geologist of Colorado. He shall prepare and submit to the advisory board, not oftener than once each fiscal year ending June 30, a regular report of 450 octavo pages or less on the work of the Survey as defined in section 2 of this act. The various reports of the Survey shall be distributed, on application, to the people of the State, used in exchange, or sold to nonresidents, as in the belief of the advisory board may best serve the interests of the State. All moneys realized from the sale of said publications shall be paid into the treasury of the State as a part of the funds of this Survey.

SEc. 4. The State geologist may appoint, with the approval of the advisory board, such temporary assistants as may be required to carry out the provisions of this act, from the teachers of geology in the educational institutions of the State, or other persons fully competent to perform the particular work required of them.

SEc. 5. Specimens and all materials for illustration or study, collected in the work of the Survey, after they have served the purpose of the Survey, shall be placed on exhibition at the headquarters of the Survey as a permanent exhibit of the Survey, except that unnecessary duplicates and excess material shall be distributed by the State geologist to the educational institutions of the State, in such manner as the advisory board may direct.

Sec. 6. The State geologist, with the approval of the advisory board, is hereby authorized to cooperate with the Director of the United States Geological Survey, under the fixed rules of the latter institution, in the mapping and geological investigation of any area in the State of Colorado, and to direct the disbursement of the funds of this Survey to that end, providing that such disbursement shall never exceed one-half the expense of the particular cooperative work so undertaken.

SEc. 7 . The reports of the State geologist shall be published in the manner that the reports of other State officers are published. 
SEc. 8. The office and headquarters of the State Geological Survey shall be the department of geology at the University of Colorado.

SEc. 9. The salary of the State geologist shall be $\$ 500$ per annum as remuneration for the proper performance of the executive work of the Survey. In addition to said salary he shall also be entitled to $\$ 10$ per diem for Survey work other than that pertaining to the executive functions of this office, except that the number of days so employed shall not exceed in any year the number of days on which he is not acting as professor of geology at the University of Colorado. The assistants to the State geologist shall receive a remuneration not to exceed $\$ 10$ per diem for such time as they are in the actual service of the Survey. The State geologist and his assistants shall also be reimbursed all necessary traveling and field expenses, providing the total of said expenses does not exceed for any person so employed $\$ 500$ for any fisc:al year.

SEc. 10. To carry out the provisions of this act the following sums be appropriated annually for the biennial period of 1909 and 1910, out of any money in the State treasury not otherwise appropriated: For the regular work of the State Geological Survey the sum of $\$ 10,000$; and the auditor of the State treasury is hereby authorized to draw his warrants upon the State treasury in payment of the moneys hereby appropriated upon certified vouchers of the State geologist. The appropriation for cooperation with the United States Geological Survey shall be conditioned upon the United States Government spending an equal amount in the said cooperative work.

SEc. 11. The State geologist and his assistants shall take the usual oath of office to perform all the services required of them under this act, and to guard as confidential all information accumulated in the progress of their work; to refrain from any pecuniary speculation based upon any knowledge of a commercial or economic nature acquired in the pursuit of their duties, until said knowledge or information shall have been fully published and submitted to the people of the State; and to turn over to the Survey as State property, all correspondence, notes, illustrations, and data of every kind accumulated by them in connection with the work of the Survey.

SEC. 12. All acts and part acts in conflict herewith are hereby repealed.

SEc. 13. In the opinion of the general assembly of the State of Colorado an emergency exists, and therefore this act should take effect and be in force from and after its passage.

Approved, April 24, 1907.

\section{ORGANIZATION.}

The form of organization of the Survey is fully defined in the law quoted above. The present personnel is as follows:Prof. R. D. George, University of Colorado, State geologist; Prof. H. B. Patton, Colorado School of Mines, Dr. James Underhill, mining engineer, Idaho Springs, Prof. G. M. Butler, Colorado School of Mines, Prof. R. D. Crawford, University of Colorado, and Prof. C. E. Smith, Colorado School of Mines, geologists; Prof. Junius Henderson, University of Colorado, paleontologist; Prof. J. B. Ekeley, University of Colorado, and Harmon Tremain, chemists; Prof. F. F. Grout, University of Minnesota, clay investigation; H. C. Woods, instructor in University of Colorado, and E. M. Kayden, draftsmen; P. G. Worcester, instructor in University of Colorado, topographer; R. M. Butters and David L. Curtis, field assistants in paleontology; G. B. Warner, R. S. 
Coffin, assistants in geology; D. A. Worcester, H. W. Thurston, field assistants; G. W. Voelzel, A. F. Mertes, R. G. Bowman, C. D. Heaton; and A. W. Lauer, assistants on clay investigation.

The average cost of field work has been $\$ 5$ a day and expenses. Advanced students serve for field expenses only.

\section{APIROPRIATIONS.}

The Survey appropriations are made biennially, and unexpended balances lapse to the State treasury immediately at the end of the biennium. The sum of $\$ 5,000$ per annum was appropriated for 1907 and 1908 and $\$ 10,000$ per annum for 1909 and 1910 .

The current appropriation is expended as follows:

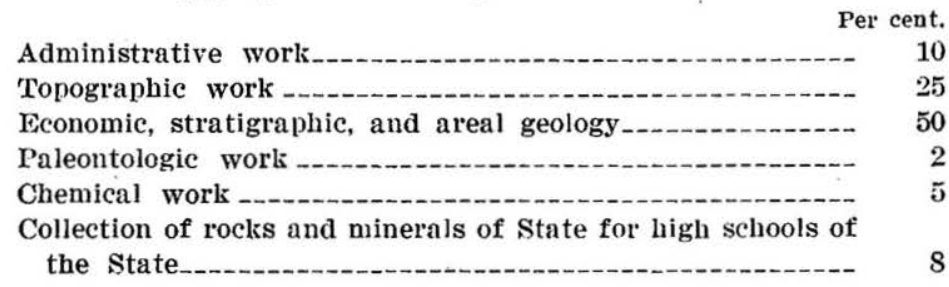

10

25

50

2

5

8

\section{PUBLICATIONS.}

The publications of the Survey consist of annual reports and bulletins. There have been issued one annual report and two bulletins. The report contains papers on the main tungsten area of Boulder County, on the Montezuma mining district, on the foothills formations of north-central Colorado, and on the Hahns Peak region. Bulletin 1 is devoted to a preliminary report on the geology of the Monarch mining district, and Bulletin 2 to the Gray Back mining district.

The publications are distributed free. The cost of printing is borne by the State and is not known to the Survey. The printing is done by State printers, but the State geologist has almost complete control over it, and he has entire control over the distribution of publications.

The mailing list includes the principal colleges and public and school libraries of the State. Publications are also sent to interested persons. The mailing list is kept alive by means of card receipts.

\section{PRESEN'T IINES OF WORK.}

The work of the Survey completed and in progress may be summarized as follows:

Field work.-(1) An area of 110 square miles about Hahns Peak, Routt County, has been mapped on a scale of 1 mile to the inch. (2) The Boulder County tungsten field, 90 square miles, has been 
mapped on a scale of 1 mile to the inch. (3) The sedimentary formations flanking the foothills have been studied and mapped from the Wyoming line southward for 75 miles, to connect with detailed work done by the United States Geological Survey farther south and complete the strip across the State. This work was done to determine the age of the formations preparatory to publishing the geologic map, and as a basis for a study of the economic deposits, such as clays, cement materials, and building stones. (4) The Montezuma area, in Summit County, 22 square miles, has been mapped in detail, both topographically and geologically.

Analyses, assays, and determinations.-In connection with the field work of the Survey about 50 complete chemical analyses and assays and more than 100 other determinations have been made. The State Survey will not do work which should go to private chemists and assayers, but only that demanded by its own reports.

Topographic map.-The Hayden Survey of the Territories, completed in 1878, made a topographic map of about two-thirds of the State. The King Survey of the fortieth parallel mapped a narrow strip about two-thirds of the way across the northern boundary of the State. Of the area not covered by these two surveys, over onehalf has been mapped in detail by the present United States Geological Survey. The other half has been mapped in less detail. The present United States Geological Survey has also mapped in greater detail a considerable portion of the area covered by the earlier surveys. The maps of the earlier surveys are available to only a very small number of people, and those of the present surveys are contained in about 60 separate sheets. The State Geological Survey has therefore compiled a topographic map of the State, on a scale of 8 miles to the inch, combining, so far as the scale would permit, the results of these surveys and including all the geographic details usually found in a complete State map. This map will be used as a base for the revised geologic map and for maps showing the various mineral deposits, water resources, and other economic features of the State. It is almost ready for the engraver, but the State Survey is waiting to incorporate in it the results of the latest work of the United States Geological Survey, which will be supplied as soon as proofs can be made. This map should be in every school and every home in the State.

Geologic map.-The only geologic map covering the State is a small one, on a scale of 12 miles to the inch, published by the Hayden Survey in 1876 and 1881. This is very general and very incomplete. The later Hayden atlas covers only two-thirds of the State. A vast amount of detailed geologic work has been done in Colorado during the last 30 years, which has modified in many important ways the conclusions reached by the Hayden geologists in their hurried survey. 
The results of the later work are published in perhaps 40 separate maps, many of which are not easily available. The State Geological Survey is therefore compiling a map, on the same scale as the topographic map, which shall bring together, so far as the scale will permit, the results of all geologic work done in the State up to the present time. The drafting is probably three-fourths done, and the explanatory sketch of the geology, to accompany the map, is well advanced.

Special maps.-A map showing the metalliferous deposits of the State is approaching completion; another showing the location of the coal fields is ready for the draftsman.

Bibliography of the geologic literature of Colorado.-This work is well advanced and already contains over 5,000 classified entries, together with reference letters indicating the important libraries of the State in which the book, article, or report may be found.

Other reports commenced.-Other reports in course of preparation include one on the distribution, qualities, and value of the clays of the State (Prof. G. M. Butler, School of Mines); one on the building stones and marbles of Colorado (R. D. George and A. P. Poorman); one on cement materials, limestone, and gypsum (direction of R. D. George); and one on the descriptive geology of the State, which will be published in two bulletins, one relating to the general geology and the other to the economic geology (R. D. George and Prof. Crawford).

Cooperation with the United States Geological Survey.-The Federal Survey offers to cooperate with the State Survey in topographic mapping on the following terms: The State to pay one-half and the Federal Government to pay one-half; the choice of the areas to be mapped to be left to the State. These terms are very liberal, and there is no State in the Union to which a complete and detailed topographic map would be of greater service than to Colorado. It is a prime necessity in the development of the water resources of the State, both for power and irrigation, and it is needed in railway construction, in the development of the mineral resources, and in many other ways.

\section{CONNECTICUT.}

\section{PREVIOUS SURVEYS.}

The first geologic survey of Connecticut was started as the result of a recommendation by Governor Edwards in his annual message to the legislature in 1835 . The legislature acted upon this recommendation by passing a resolution "that the governor be, and is bereby, authorized to appoint a committee of suitable persons to make a geological survey of the State of Connecticut." After considerable persuasion, James Gates Percival and Charles Upham Shep- 
ard were induced to serve as the committee called for by this resolution. It was agreed that Percival should undertake the study of the general geology of the State and Shepard the study of the mineralogy and economic geology. Shepard's report was dated May 15, 1837, and by order of the legislature 2,000 copies of it were printed. The task which Percival had undertaken was more extended and difficult. In the spring of 1838 he presented a manuscript report but considered the work so incomplete that he was unwilling to have the report printed. Year after year he labored, on a very small appropriation, while the State authorities became more and more impatient for the publication of some definite results. Finally, in 1842, an edition of 1,000 copies of his " Report on the geology of the State of Connectícut" was printed. This report is merely a description of the local distribution of several geologic formations, designated in the text and on the map by an elaborate notation of Roman letters, Greek letters, and punctuation marks. But students of Connecticut geology, in the three score and more years which have elapsed since the publication of Percival's book, have regarded it with admiration for the conscientious thoroughness with which the study of the areal geology of the State was accomplished.

The only other work at all in the nature of a geologic survey, which was done under the auspices of the State of Connecticut before the organization of the present Survey, was the topographic survey for which provision was made by act of the legislature in 1889 . According to this act a commission was appointed by the governor "to confer with the Director or representative of the United States Geological Survey, and to accept its cooperation" in the preparation of a topographic map of the State. The State appropriated a sum not exceeding $\$ 25,000$, on condition that an equal amount should be expended by the United States Geological Survey. The amount actually expended was a few hundred dollars less than the maximum specified in the resolution. The commissioners appointed to represent the State were William H. Brewer, James H. Chapin, and John W. Bacon. The work was begun in July, 1889, and was completed in 1893.

\section{PRESENT SURVEY.}

LEGAL DESIGNATION AND DATE OF ORGANIZATION.

The present organization is designated the State Geological and Natural History Survey; it was organized under an act approved June 3, 1903.

\section{SUMMARY OF LAWS.}

The law under which the Survey operates provides for a commission, composed of the governor of the State and the presidents of Yale University, Wesleyan University, Trinity College, and the 
Connecticut Agricultural College. The commissioners serve without compensation, but are entitled to reimbursement for actual expenses incurred. They have power to appoint a superintendent and such other employees as they may deem necessary and to fix the rate of compensation to be paid them. All appointees are subject to removal at the pleasure of the commissioners.

The Survey is directed to study the geologic formations and the animal and plant life of the State, also to give special attention to economic products and to render such service as it can to the educational institutions of the State. Material collected by the Survey may, at the discretion of the commissioners, be distributed to educational institutions of the State or be retained for exhibition purposes:

The law provides that biennially a report of the progress and condition of the Survey shall be submitted to the legislature, and also that special reports on subjects investigated, accompanied by proper illustrations and maps, may from time to time be published.

ORGANIZATION.

Soon after the passage of the act just described, William North Rice was appointed superintendent of the Survey, and he has continued to hold office until the present time. The tenure of office of the superintendent is at the discretion of the commissioners. His salary, which is fixed by the commissioners, is $\$ 200$ a year, with an annual allowance of $\$ 150$ for traveling and other expenses. The salary is paid in quarterly installments. Bills for expenses are presented to the State comptroller. In view of the small salary the superintendent is not expected to give a large part of his time to the work of the Survey. The present superintendent is professor of geology in Wesleyan University and receives the full salary of a professor in that institution. His time is therefore devoted chiefly to college work.

Since the organization of the Survey no other salaried officers have been appointed. Scientific men have, from time to time, been engaged for special investigations, with the understanding that on the completion of the investigation a report would be submitted which, if accepted by the superintendent, would be published as a bulletin of the Survey. Most of the contracts made with scientific men have specified the payment of a certain sum on the completion of the work and the acceptance of the manuscript by the superintendent. An allowance for expenses, to be drawn upon as occasion required, has also been made to them. This allowance covers traveling expenses, clerical assistance, and the employment of students or others for the working out of details required by the scientific investigator. 
In cases where it was impossible to make a definite estimate regarding the amount of work involved in an investigation, the contract with the scientific man has provided for the payment of a certain sum. per diem for time employed in field or laboratory work. In these cases, however, a maximum sum for the investigation has been specified. Other contracts have provided for a per diem compensation for field work, and in addition the payment of a specified sum upon the completion of the manuscript and its acceptance by the superintendent.

All contracts with scientific men are subject to the approval of the commissioners. These men, like the superintendent, have performed their work for a nominal compensation-a few of them for no compensation-and have therefore devoted to it only the time they could spare from other professional duties. Most of them have been professors or instructors in colleges; some have been graduate students. The investigation assigned to a man has usually been one which he had already undertaken because of its congeniality.

\section{APPROPRIATIONS.}

Appropriations are made by the legislature at each biennial session. The Survey has not yet been granted continuing appropriations. Each appropriation is good for two years and unexpended balances lapse into the State treasury. It is, however, the rule of the comptroller's office that for a period of six months after the expiration of the biennial term an appropriation may be drawn upon to satisfy contracts made before the expiration of the biennial period.

The appropriation is $\$ 3,000$ for each biennial term. This amount is to cover all salaries and expenses of the Survey except the cost of printing and engraving. The appropriation is expended under the direction of the commissioners. As the Survey is designed to cover the geology, zoology, and botany of the State the endeavor has been to divide the appropriation about equally between geology and biology. It has been disbursed in about the following proportions:

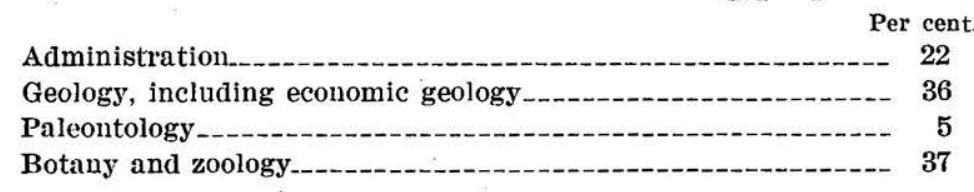

PUBLICATIONS.

The publications of the State Geological and Natural History Survey of Connecticut number 17. Of these four are biennial reports, fire relate to geology, and the remainder to biology. The geologic publications comprise a report on the clays and clay industries of the State, a manual of the geology of Connecticut, a preliminary 
geologic map of the State, a bibliography of Connecticut geology, and a report on the lithology of the State.

The law provides for the publication of a biennial report of the progress of the Survey and for the publication of special reports fron time to time. The size of the editions has varied from 3,000 to 4,000 copies, according to the estimated demand. The bulletins are distributed by the State librarian in accordance with regulations adopted by the commissioners. The mailing list includes the United States Geological Survey, State geological surveys, colleges, scientific schools and societies, academies and high schools within the State, scientific journals, the newspapers of the State, and to a limited extent the newspapers of adjacent States; also botanists, zoologists, and geologists. On application, teachers, advanced students, and citizens of the State are, whenever possible, supplied with bulletins on subjects in which they are specially interested. Although the commissioners have adopted a very liberal policy in the distribution of Survey publications, a price is fixed on each bulletin and they are sold to persons who have no special claim to receive them gratuitously. The income from sales is, however, insignificant. It goes into the State treasury.

The total cost of printing from the organization of the Survey in 1903 to April 1, 1990, was $\$ 12,582$. Under the law establishing the Survey it was the intention that the cost of its publications should come out of the general appropriation for the printing of public documents. This intention, however, has been frustrated by an unfortunate oversight. A general law of the State limits the number of copies of any public document to 1,575 (with the exception of certain specified classes of documents) and provides for the distribution of a large part of the edition to State, county, and town officers. If the Survey bulletins were limited to the number prescribed by this general law, and if they were distributed in the manner indicated, the result would be that they would not reach the institutions and people who could use them. Special legislation was therefore necessary to authorize the printing of larger editions of Survey bulletins, and this was accompanied by the specification of a limit for the expenditure. The legislatures of 1907 and 1909 limited the biennial appropriations for Survey printing to $\$ 5,000$.

The printing is done under the supervision of the State comptroller. The paper, size of page, and general typographic style are the same as in other public documents. Special contracts for maps and illustrations are made with the approval of the comptroller. The printing of each bulletin must be formally sanctioned by the board of control, which is composed of the governor, State treasurer, comptroller, and' attorney general.

$$
85645^{\circ}-\text { Bull. } 465-11-3
$$




\section{PRESENT LINES OF WORK.}

Geology.-At present the geologic investigations relate chiefly to Quaternary geology, the following bulletins being in course of preparation: One on the Quaternary geology of the Naugatuck Valley, by Prof. H. E. Gregory; one on the glacial geology of the New Haven region, by Dr. Freeman Ward; and one on the terraces of the Thames, by Dr. F. P. Gulliver. There is also in contemplation a general paper on the Quaternary of Connecticut, to be illustrated by a map. A bulletin on the peat deposits of Connecticut, by Prof. C. A. Davis, will soon be published. This bulletin will treat of the purely scientific as well as the economic aspects of the subject.

Paleontology.-Two paleontologic papers are under way, one on Triassic fishes, by Dr. C. R. Eastman, and the other on the footprints of the Triassic sandstones, by Prof. R. S. Lull.

Biology.-Bulletins on certain groups of insects are in course of preparation, also on echinoderms and Crustacea of the Connecticut coast and on the birds of the State.

Cooperation with United States Geological Survey.-There has been no cooperation between the United States Geological Survey and the present State Survey, except in connection with the peat investigation, the only cooperation with the Federal organization on any extensive scale having been in connection with the topographic survey of the State, which was completed before the organization of the present Survey. Negotiations are in progress looking toward cooperation in an investigation of the water resources of the State.

\section{FLORIDA.}

\section{PREVIOUS SURVEYS.}

Before the organization of the present Geological Survey of Florjda only a very small amount of geologic investigation had been conducted by the State. In 1853 the general assembly of Florida passed an act establishing the office of State engineer and geologist. The geologic part of the work, however, seems not to have been provided for. The first report of the State engineer and geologist comprises pages 19 to 36 of "Documents accompanying the message of the governor of Florida," submitted November 28, 1854. That part of the report relating to geology occurs on page 20 of the appendix and reads as follows:

On the subject of the geology of the State, I have made no report, from the fact that the general assembly failed to specify any appropriations to defray any expenses incurred in reference to the matter. Consequently nothing has been done by me, except to obtain specimens of soils and minerals from the various localities (where marked changes were perceptible), visited by me in the performance of the duties of engineer. 
The office of State engineer and geologist was abolished by an act of the legislative assembly of 1855 .

In 1886 Governor Perry appointed Dr. J. Kost State geologist of Florida. This appointment seems to have been made with the ex-. pectation that a continuance of the geological survey would be provided for by the legislative assembly of the following year. This expectation, however, was not realized. During his temporary service as State geologist Dr. Kost traveled somewhat extensively in the State, and early in 1887 published a preliminary report entitled "First report of the geological survey of Florida." This report contains observations on the geology, physical geography, soils, and timber of the State, with remarks on the phosphates, lime, marls, clays, iron, coal, building stone, and mineral waters.

\section{PRESENT SURVEY.}

LEGAL DESIGNATION AND DATE OF ORGANIZATION.

The present organization is entitled the Florida State Geological Survey; it was organized in June, 1907.

\section{SUMAARY OF LAWS AND ORGANIZATION.}

The law under which the Survey is established provides for the appointment by the governor of a State geologist, and for the appointment by the State geologist, subject to the approval of the governor, of such assistants as may be necessary to conduct the survey successfully and with reasonable dispatch, the assistants to be entirely under the control of the State geologist.

The State geologist is required to annually make to the governor a report of the progress of his surveys and explorations. In case of the discovery of mineral deposits or other substance of value the State geologist is required to notify the owner of the land upon which such deposits occur before disclosing the fact to any other person or persons.

Provision is made for the collection of specimens illustrating the geologic and mineral features of the State. One suite of the specimens is to be deposited in the office of the State geologist, and duplicate suites are to be sent to the State colleges.

The title of the executive officer is State geologist. The present incumbent, E. H. Sellards, was appointed June 19, 1907. The term of office of the State geologist is not specifically mentioned in the law establishing the Survey, but his salary is fixed at $\$ 2,500$ per annum. All other expenses are paid by the comptroller, upon the requisition of the State geologist, approved by the governor. The assistants at present include one clerk and two assistant geologists. The chemical analyses required by the Survey are made by the State chemist. 


\section{APPROPRIATIONS.}

The appropriations are continuing and are not contingent upon cooperation. Unexpended balances carry to the next fiscal year. The annual appropriation is $\$ 7,500$. The objects of expenditure, within the general purposes of the Survey, are not fixed by law. The expenditures are distributed approximately as follows:

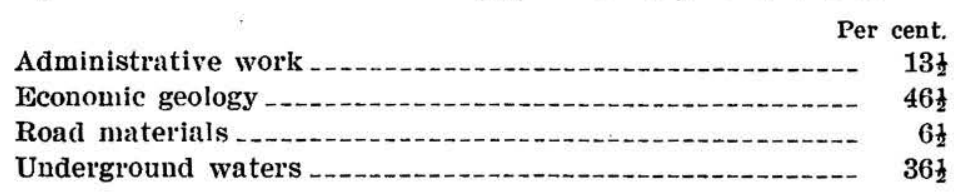

PUBLICATIONS.

The publications include annual reports, bulletins, and circulars. Two annual reports, one bulletin, and two circulars have been issued. The edition is 2,500 to 5,000 copies. All reports are distributed free.

The average annual cost of printing and engraving is $\$ 1,500$. This is paid from the regular Survey appropriation.

At present, within the limit of the funds available, there are no limitations in choice of printer or style of report. The reports are distributed by the Survey. The mailing list includes standard libraries and all persons or firms requesting reports.

\section{PRESENT LINES OF WORK.}

Independent investigations.-The phosphate deposits of the State constitute the principal investigation at present.

Cooperation with United States Geological Survey.-In cooperation with the Federal Survey investigations are being made of the peat deposits and the water supplies of the State.

Cooperation with other scientific bureaus.-In cooperation with the department of civil engineering of the Florida State University the road materials of the State are being studied.

\section{GEORGIA.}

\section{PREVIOUS SURVEYS.}

The first effective effort toward the establishment of a Geological Survey of Georgia had its beginning in Governor Schley's message to the general assembly in 1836. The governor, in discussing the internal improvement of the State, wrote as follows:

Intimately connected with this subject is that of the geological structure of the State and of its mineral resources. A proper knowledge of these is necessary to a prudent and profitable location of canals and railroads and should. have its influence in directing their course. Thus far, Georgia has scarcely 
looked beneath her surface, and her great staple commodity has been the only article of transportation within the contemplation of those who have projected schemes of internal improvement, whilst the advantage to be derived from geological investigation has been entirely overlooked. In such a survey the whole State is interested, not merely in the increased variety of its products, but in the promotion of the most efficient culture by disclosing the character and capacity of the soil. Her territory, particularly that part comprehended within the Cherokee circuit, is believed to abound in mines of gold, marble, iron, limestone, salt, and other valuable minerals. These concealed treasures, which should be made tributary to her knowledge and wealth, are worthy of your enlightened consideration, and the provision necessary to a full and scientific examination of them ought not to be longer delayed. I suggest, therefore, the propriety of employing a competent geologist to make a thorough survey of the State, with a view to the ascertainment of its mineral and agricultural resources and the proper location of works of internal improvement.

Governor Schley supplemented the foregoing recommendation by the following note:

Since the above was written, I have received from $\mathrm{Mr}$. Joln $\mathrm{R}$. Cotting a letter dated at Augusta on the 15th ultimo, accompanied by a report of a geological and agricultural examination made by him, during the past summer, of the counties of Burke and Richmond. This survey was executed at the expense of individuals of these counties and is highly creditable to their public spirit and, as far as I can judge, equally so to the skill and capacity of Mr. Cotting as a scientific and practical geologist. I avail myself with pleasure of the opportunity thus afforded me of sending to the house of representatives this letter and report, with the hope that they may add force to the recommendation I have submitted.

Acting upon the recommendation of the governor, a committee was appointed by the legislature to consider the propriety of establishing a Geological Survey. This committee made the following report to the general assembly on November 26, 1836:

Resolved, That his excellency the governor be, and he is hereby, authorized to employ as soon as practicable one or more suitable and qualified persons to undertake the work of a careful and scientific survey of all the counties in this State, under his instructions and advice.

Be it further resolved, That the sum of $\$ 10,000$ be appropriated for that purpose, subject to the warrant of the executive out of any moneys in the treasury, not otherwise appropriated, and the same be inserted in the appropriation act of this session of the general assembly.

The report above referred to by Governor Schley, on the counties of Burke and Richmond, paid for by the citizens of those counties, was a small volume of 189 pages, bearing the date of 1836 . This report was devoted chiefly to the economic geology of the crystalline and Tertiary formations of Burke and Richmond Counties and formed a part of the annual report of Prof. John R. Cotting, State geologist, for the year 1837.

Under the resolution above referred to, Gov. Schley appointed John R. Cotting State geologist. His first annual report to the general assembly was made in 1837 . It covered, more or less completely, 
the counties of Chatham, Columbia, Effingham, Screven, Burke, Richmond, Lincoln, Elbert, Franklin, Habersham, and parts of Wilkes and Oglethorpe. The special committee, to which this report was referred, reviewed it in considerable detail, pointing out the important discoveries made in the location of valuable marl and graphite deposits, and also referring to important work done in establishing the variations of the magnetic needle at 20 different points in the counties in which work had been carried on. In addition to those investigations, the report stated that considerable time had been devoted to the study of the flora of the counties surveyed, about 1,200 specimens of plants having been collected. The committee recommended that the report of the State geologist be published and that copies of the tables of magnetic variation be sent to the clerks of the inferior courts of the several counties surveyed, where they were to be preserved for the benefit: of county surveyors and others interested. For some reason, not given in the house journal, this recommendation was not favorably acted upon by the general assem. bly, and as a consequence the State geologist's report for 1837 was never published.

As the house journal for the year 1838 has apparently been lost, nothing is known of the action of the general assembly in regard to the Geological Survey until 1839, when a resolution was introduced in the house asking that the Geological Survey be abolished, on the ground that it had spent all of the $\$ 10,000$ appropriated to carry on the work without any benefit whatever to the citizens of the State. This resolution was adopted by the general assembly in 1840, and the Survey was accordingly discontinued.

Efforts to reestablish the Survey were unsuccessful until 1874, when an act was passed by the general assembly appropriating $\$ 10,000$ annually for a term of five years for the purpose of making a "geological, mineralogical, and physical survey" of the State. This act was similar to the act under which the present Survey operates. It was approved February 27, 1874, and in August Dr. George Little was appointed State geologist by the governor. During Dr. Little's term of office he made two annual reports of progress, one of 36 pages, covering the period from September 1 to December 31, 1874, and the other of 16 pages, bearing date 1876. In addition to these two reports of progress, Dr. Little in 1876 published (in the "Handbook of Georgia," issued by the State Agricultural Department) a paper of 126 pages treating of the geology, mineralogy, climate, water powers, soils, etc., of the State. These publications, together with a 16-page catalogue of ores, rocks, and woods selected for the Paris Exposition, are apparently the only ones issued by the Survey.

Between the date of the abolishment of this Survey in 1879 and its revival in 1889, a limited amount of geologic work was done by the 
State Department of Agriculture, the results of which were published in the volume "Commonwealth of Georgia," bearing the date 1885.

\section{PRESENT SURVEY.}

LEGAL DESIGNATION AND DATE OF ORGANIZATION.

The present Survey is entitled the Geological Survey of Georgia; it was organized in 1889.

HISTORICAL SKETCH.

The present Survey began its work in July, 1890, with Dr. J. W. Spencer as State geologist. The law under which the Survey began operations was practically the same as that now in force. Dr. Spencer remained in office until 1893. During his incumbency two reports were published, one termed an administrative report, bearing date July 1, 1891, and the other entitled "The Paleozoic groupGeology of ten counties of northwest Georgia and resources." The former report, devoted largely to the Cretaceous and Tertiary formations of the coastal plain, contained 144 pages; the latter contained 406 pages and a geologic map of northwestern Georgia.

Prof. W. S. Yeates was appointed State geologist in July, 1893, and continued in office until his death, which occurred February 18, 1908, when S. W. McCallie, the present incumbent, was appointed.

\section{SUMMARY OF LAWS.}

The law under which the Survey operates is as follows:

State geologist.-The governor shall appoint, with the consent of the advisory board, a competent person as State geologist, who shail have a thorough scientific and practical knowledge of the science of geology and mineralogy and who is not connected with any school or college as an instructor. The State geologist shall enter upon the duties of his office on the 1st of July, 1899, and shall hold until removed by the appointing power for inefficiency, incompetency, or misconduct, or until the office is abolished by the general assembly. The office of the State geologist shall be at the seat of government.

Advisory board.-There shall be an advisory board, consisting of the governor of the State (who shall be president of the board), the commissioner of agriculture, the State school commissioner, the State treasurer, the comptroller general, the secretary of state, and the attorney general. Four members present at any meeting shall constitute a quorum for the transaction of any business.

Duty of geologist.-It shall be the duty of the State geologist to give his attention to the administration of the affairs of the Survey; to visit all parts of the State, so as to make himself familiar with the needs of each section; to supervise the work of his assistants, including all reports submitted by them for publication; to undertake such field work as his time will permit; and to perform such other duties as properly pertain to his office. 
Assistant State geologists.-Two competent assistant State geologists shall be chosen by the State geologist, who may remove them at any time for incompetency, inefficiency, or misconduct. As soon as a general outline of a geological survey of the entire State shall have been made, the State geologist shall divide up the work between himself and his assistants in such way as shall be to the State's best interest, and under his direction and control the corps shall proceed to make a careful and complete geological, mineralogical, and physical survey of the State; to enter unon record, to be kept for that purpose in his office, an accurate statement of the extent of all water powers, roads, springs, and watercourses, and the climate, topography, and general physical character of the country, and locate the belts of ores, useful minerals, and building materials; to report characteristics and composition of soils and the deposits of marls and phosphates; to collect, analyze, and classify specimens of minerals, rocks, ores, fossils, and soils and enter the same on record; to cause to be preserved in a museum specimens illustrating the geology, mineralogy, soils, and whatever else may be discovered in the mineral or geological resources of Georgia having scientific or economic value; and he shall make a report of the survey of every county of this State, accompanied with all necessary maps and illustrations.

Survey of watercourses, lakes, etc.-It shall also be the duty of said State geologist to make a survey of the watercourses, nonds, lakes, and swamp region of Georgia, and submit, in the report provided for, a topographical map showing the location, extent, means, and plans of drainage, and also an estimate of the cost of said drainage of the ponds, lakes, and swamps of Georgia. The said State geologist shall also make an estimate of the value and extent of the lands to be reclaimed by said drainage.

Employment of topographers and drivers.-The State geologist is hereby authorized to employ two competent topographers and four assistant topographers and two drivers, as may be necessary to carry out the purpose of this chapter.

Statc geologist to supervise.-The State geologist shall have supervision of the entire work of the Survey, and shall be responsible for the accuracy of the same. It shall be the duty of the State geologist to make report to the advisory board once every three months-to wit, on the second Wednesdays in March, June, September, and December of each year.

No special surveys. - No individual, firm, or corporation shall have the right to call upon or require the State geologist to enter upon any special survey for his or their special benefit; but the Survey is to proceed upon a settled plan for the benefit of the public and investors and developers in general.

Supervision of expenses by board.-The advisory board shall have the supervision of the money expenditures in the prosecution of the work contemplated. The State geologist shall make to the advisory board monthly statements under oath of all incidental expenses necessarily incurred by himself and his assistants, accompanied by proper vouchers, in the discharge of their labors. The board shall audit such accounts, item by item, and approve or reject the same, as in their judgment may be right. When an account is allowed the governor shall draw his warrant for the amount thereof. The governor, with the advice and consent of the board, may at any time suspend the field operations.

His salary. -The salary of the State geologist shall be $\$ 2,500$ per annum, and each assistant shall receive such salary per annum as shall be determined by the advisory board of the Geological Survey on the recommendation of the State geologist: Provided, That each assistant shall not receive more than $\$ 1,500$ per annum. 
Specialist.-The State geologist, with the consent of the board of advisement, may employ a specialist or specialists at any time.

When results of surveys may be published.-Neither the State geologist nor his assistants shall disclose to any person, except to the owner of the land, the result of a survey until the same is made public by publication of the report by the advisory board.

Maps of surveys State property.-The State geologist and his assistants shall deposit in the office of the governor all maps, surveys, notes, or memorandum of surveys when the surveys are completed, which are hereby declared to be the property of the State.

ORGANIZATION.

Details regarding the organization of the Survey are given under "Summary of laws." The executive officer is the State geologist. The present incumbent is Prof. S. W. McCallie.

\section{APPROPRIATIONS.}

Appropriations are made biennially and are not contingent upon cooperation with the United States Geological Survey. Unexpended balances lapse into the State treasury in the July following the year for which the appropriation is made. The amount of the appropriation is $\$ 10,000$ per annum for the maintenance of the Survey and $\$ 2,500$ per annum for printing. The manner in which the appropriations are to be expended is covered in a general way by the law organizing the Survey. Heretofore the energy of the Survey has been devoted largely to economic problems, though considerable work has been accomplished on the stratigraphic and areal geolbgy of the State, as well as on the water resources and highway improvements.

PUBLICATIONS.

The publications of the present Survey comprise the 1891 administrative report of Dr. Spencer and his "Paleozoic group," also a series of bulletins, numbered from 1 to 24 , inclusive. The bulletins pertain chiefly to the economic geology of the State, but two are devoted to the water powers of Georgia, two to the underground waters of the State, and two to roads and road-building materials.

The State geologist has control of the printing of reports, maps, etc. The size of the edition is 3,000 copies, 1,500 of which are bound in cloth and 1,500 with paper cover. The reports are sent to any applicant on receipt of postage. In addition, copies are mailed to all the leading papers and colleges of the State, to all State geological surveys, to many libraries in this country, and to some foreign libraries. 


\section{ILLINOIS.}

\section{PREVIOUS SURVEY.}

The first Geological Survey of Illinois was created by the general assembly in 1851. It was placed in charge of a geologist appointed by the governor, auditor, and treasurer. The duties of the geologist were, briefly, "to ascertain the order, successive arrangement, relative position, dip, and comparative magnitude of the several strata or geological formations in the State, and to search for and examine all the beds and deposits of ores, coal, clays, marls, rocks, and such other mineral substances as may present themselves; to obtain chemical analyses of the same, and to determine by barometrical observations the relative elevation of the different portions of the State." $\mathrm{He}$ was also required to transmit an annual report, accompanied by necessary illustrations, for printing and distributing in such manner as the governor might indicate. Provision was also made for the collection of a cabinet of specimens found within the State, from which duplicates were to be distributed to the larger institutions of learning. The act provided a continuing annual appropriation of $\$ 3,000$. This, however, was increased by the next legislature to $\$ 5,000$ for general expenses and $\$ 500$ per annum for topographic maps of the counties.

Dr. J. C. Norwood was in charge of the Survey for the first six years after its organization. He began work with an examination of the bluffs of Ohio River in southern Illinois. In six years about $\$ 27,000$ had been expended, but no report had been submitted. An investigating committee found that the money had been wisely spent and recommended an additional appropriation for the completion of the work. Norwood's only publication, bearing the date of 1857, was a small octavo pamphlet of less than 100 pages devoted to the discussion of Illinois coals. It was accompanied by a one-page colored map of the State.

In 1858 Norwood turned over to his successor, Dr. A. H. Worthen, the field notes of several assistants and a report on the lead mines in Hardin County. The first report submitted by Worthen was devoted to two geologic sections, one across the Silurian and Devonian formations of southern Illinois, and the other following Mississippi River from end to end of the State. This report and the others submitted previous to 1865 were never published, owing to the opposition of certain members of the legislature. Indeed, an attempt was made to repeal the law under which the Survey was organized, and only the interference of the executive veto saved the organization.

Worthen reorganized the Survey and obtained the services of a number of specialists. J. D. Whitney was authorized to investigate the lead and zinc region of northwestern Illinois, and Prof. Leo 
Lesquereux was engaged to investigate the "Coal Measures" and the Carboniferous plants. The assistance of F. B. Meek in the investigation of invertebrate fossils, and of Dr. J. S. Newberry in the department of vertebrate paleontology was also secured. The chemistry of the Survey was placed in the hands of a specialist, and the following other scientists shared the work of the first Survey : Engelmann, Prout, Bannister, Freeman, Scudder, Bradley, Green, Shaw, Broadhead, Cox, St. John, Miller, Wachsmuth, Barris, Springer, Ulrich, and Cope.

The Survey continued to receive appropriations for active work until 1872, when the old Illinois constitution was abolished and the continuing appropriation for Survey work ceased. At that time several volumes of reports had appeared and others were in course of preparation. For the purpose of completing the reports in hand small appropriations were made until 1875 , when all provision for the Survey terminated. At that time six volumes of reports had been issued and two other volumes were partly completed.

In 1877 the State Museum of Natural History was created and placed in control of the geologic collections. The former. State geologist, A. H. Worthen, was appointed the first curator of the museum, but he was not provided with funds for field work or for publications. It was not until 1881 that the curator was directed to issue Volume VII of the reports of the former Geological Survey, and the publication of the last volume was not authorized until 1885.

The reports of the first Geological Survey are of a high scientific character and are monuments to the ability of Dr. Worthen and his associates. In addition to reports on 102 counties of the State, the following subjects were treated with greater or less thoroughness: Physical features of Illinois; general geologic principles; surface and stratigraphic geology of the State; paleontology of Illinois rock formations; the "Coal Measures," "sub-Carboniferous" limestone, and the Devonian and Silurian systems; geology of the lead region; coal fields of Illinois; and the origin and formation of the prairies.

So far as can be learned the eight royal octavo volumes were published in editions of 3,000 each and were distributed gratuitously under the direction of the governor. They averaged about 550 pages each. About 285 full-page lithographic plates, besides numerous woodcuts, were published. Altogether about $\$ 110,000$ was appropriated for the maintenance of the first Survey, including illustration of reports. Apparently the cost of printing and binding came from another fund.

The broad scope of the work of the first Survey has been indicated. Its notable accomplishments were recognized by scientists of the whole world. The pioneer work which it performed in American paleontology is of the highest order and constitutes one of the stand- 
ards on which paleontologists of the present day work. The reasons which led to the discontinuance of the Survey are not difficult to find. During the early years Illinois was almost exclusively an agricultural State. Rock formations were largely hidden from view by thick deposits of drift and consequently did not seem to the layman of sufficient importance to warrant expensive study. Coal for fuel, brick and stone for building, and other minerals were not in general use during the days when timber was plentiful. It may well be imagined, therefore, that the expenditure of large sums on investigations of that nature and on the description and illustration of fossils was unappreciated by the early citizens. When, therefore, in 1875 the county reports for the entire State were completed, further work of the Survey was checked by the failure of appropriations.

After the discontinuance of the first Geological Survey there was a period of 30 years of inactivity in geologic investigations in Illinois, the work of that nature performed by the State Museum not being sufficient to justify special mention.

\section{PRESENT SURVEY.}

LEGAL DESIGNATION AND DATE OF ORGANIZATION.

The present organization is entitled the State Geological Survey; it was organized under act of July 1, 1905.

The first director was Dr. H. Foster Bain, who served until his resignation in 1909.

\section{SUMMARY OF LAWS.}

The Survey, which is established at the University of Illinois, operates under the direction of the State geological commission. This commission is composed of the governor, who is the chairman; the president of the University of Illinois; and one other competent person appointed by the governor for a term of four years and until his successor is appointed and qualified. The commissioners serve without compensation, but are reimbursed for actual expenses incurred in the performance of official duties. They have general charge of the Survey, and appoint the director, who, with the approval of the commission, appoints necessary assistants and em: ployees. The salary of the director and of the assistants and employees is determined by the commission.

The objects of the Survey are as follows:

(1) A study of the geologic formations of the State with special reference to its products-coals, ores, clays, building stones, cements, materials for use in the construction of roads, gas, mineral and artesian water, and other mineral resources. 
(2) The preparation of geologic and other necessary maps to illustrate the resources of the State.

(3) The preparation of reports, with necessary illustrations and maps which shall include both a general and detailed description of the geologic and mineral resources of the State.

(4) The consideration of such other scientific and economic questions as in the judgment of the commissioners shall be deemed of value to the people.

The director presents to the governor an annual report showing progress and condition of the bureau and such other information as the commission requires. The reports of the Survey are printed and distributed gratuitously as well as sold. All money received from sale of reports is paid into the State treasury.

The printing of reports and of stationery forms a part of the State printing contract, and is under the direction of the board of commissioners of State contracts. The amount thus expended in any one year is limited to $\$ 5,000$. More recently an appropriation of $\$ 2,500$ per annum has been made to the State geological commission for preparing and engraving illustrations and maps and for printing and binding reports.

Collections of materials which have served the purpose of the Survey may be distributed to the educational institutions of the State, or be placed in the State. Museum of Natural History at Springfield or in the museums at the University of Illinois, as indicated by the commissioners.

The sum of $\$ 25,000$ per annum is appropriated biennially to provide for the work of the Survey. Vouchers, when approved by the governor, are presented to the auditor of public accounts. For the present biennium the additional sum of $\$ 7,500$ has been appropriated for the survey of overflowed lands in Illinois.

The commission is authorized to cooperate with the United States Geological Survey in the preparation of a topographic map of the State, and to expend in the prosecution of that work a sum equal to that expended by the Federal Survey, but this amount shall not exceed $\$ 10,000$ in any one year.

It is lawful for persons employed in the work of the Survey to enter and cross all lands within the State, provided in so doing no damage is done to private property.

\section{ORGANIZATION.}

The form of organization of the Survey is outlined in the preceding summary of laws. At present the personnel is as follows:

The governing board is the State geological commission, whose chairman is Gov. Charles S. Deneen; the vice chairman is Prof. 
T. C. Chamberlin, of the University of Chicago; and the secretary is President E. J. James, of the University of Illinois.

The executive officer is known as director. The present incumbent, appointed acting director April 1, 1909, and director January 12, 1911, is Frank W. DeWolf. The director is appointed by the commission and holds office at the pleasure of that body. He is required to devote his time exclusively to the official duties of the Survey.

Subordinates include clerical, geologic, chemical, technologic, topographic, engineering, and hydrographic assistants. They may be appointed for any term and at any designated rate of compensation. Appointments may be made by the commission or by the director, subject to approval by the commission. The clerical force includes a chief clerk and a stenographic assistant. In addition, students are from time to time employed for routine work. Salaries of male clerks have ranged from $\$ 60$ to $\$ 125$ a month and of female clerks from. $\$ 30$ to $\$ 50$ a month.

In the organization of the scientific work there are three consulting geologists, two consulting chemists, and one consulting ceramist. The other scientific employees rank as geologists, assistant geologists, and field assistants. The range of pay, in addition to allowance for actual expenses, is as follows: Consulting geologists, $\$ 8$ per diem; consulting chemists and ceramist, a per diem amount corresponding to the salary of university professors; geologists, $\$ 150$ to $\$ 200$ a month; assistant geologists, $\$ 100$ to $\$ 135$ a month; field assistants, up to $\$ 100$ a month.

The three consulting geologists represent the geologic departments of the three largest universities of the State, and are men of extended experience on official surveys. Each of these advisers shares responsibility for the direction of a particular investigation. At present one is adviser in clay investigations, another in studies of lead and zinc, and the third in the preparation of educational bulletins. The service of the consulting geologists is discontinuous, both in the field and in office.

Other geologists of the organization are selected for work in which they are thoroughly experienced and responsible. At present they include three professors, who devote from two to four months of each year to field work and prepare their reports during the succeeding university year as time can be separated from their college duties. Two of these geologists give special attention to paleontologic stratigraphy, and the third to the study of well records and detailed areal and economic investigations.

The assistant geologists include men with several years' experience, who are thoroughly competent to pursue individual work. As a rule two such assistants are employed for full time and from two to four others devote the summer months only to the work of the Survey. 
Field assistants may have had little or no practical experience but are required to have had a thorough collegiate instruction in geology. They are usually postgraduate students or instructors in the State universities. Occasionally inexperienced men work without salary but are reimbursed for expenses. From three to six field assistants are employed each year.

\section{APPROPRIATIONS.}

Appropriations are made biennially, and for the most part in two annual installments. None are contingent on cooperation.

The fiscal year of the State begins October 1. Appropriations become available July 1 , and unexpended balances lapse before October of the following year. Under construction of the auditor, June bills can be paid from the appropriations which become available July 1.

The sum of $\$ 25,000$ per annum is appropriated biennially, to provide for official expenses incurred by the commissioners and for the payment of salaries (or other compensations) and expenses of the director and other employees. The method of disbursement is by means of vouchers approved by the governor and presented to the auditor of public accounts. In addition to the above regular appropriation there has been appropriated for the present biennium the sum of $\$ 7,500$ for the survey of overflowed lands in Illinois and $\$ 2,500$ per annum for preparing and engraving illustrations and maps and printing and binding reports of the Survey.

The average annual expenditures may be classified under the following heads; the percentages are for the current year, but are fairly representative.

Administrative, and routine clerical work, including postage

on bulletins_........... 22

Per cent.

Topographic work

Economic, stratigraphic, and areal geology______._._._. 21.5

Statistics _-._-

Chemical work

Underground water resources_._-_._- 1.6

Drainage surveys _._.

Tests of clay-_-_. 9

Library _..._.

Drafting and engraving-_-_- 3.8

Educational bulletins__-_-_. 2.5

100.0

PUBLICATIONS.

The publications of the present State Geological Survey comprise bulletins 1 to 16 , inclusive, and circulars 1 to 5 , inclusive. The bulletins include the annual administrative reports, a geologic map 
of the State, economic reports, special physiographic studies, and reports on the mineral content of the waters of the State and on the water resources of certain districts. The circulars are of a statistical nature and relate to the annual mineral production of the State.

The size of the editions of Survey publications varies from 3,000 to 4,000 copies, according to the character of the report and its probable demand.

A portion of each edition is set aside for gratuitous distribution. To meet the wants of libraries and persons not reached in this first distribution, 500 copies of each edition are reserved for sale at cost, including postage. All money received from the sale of reports is paid into the State treasury. The amount is small, varying from $\$ 70$ to $\$ 100$ per annum.

The average annual cost of printing reports and accompanying maps for the last five years is about $\$ 5,000$. Of this, $\$ 1,200$ has come from Survey funds, and the remainder from the State printing fund. The cost of cuts for illustrations and of the actual printing of colored maps is paid from Survey funds.

The printing of reports and of stationery forms a part of the State printing contract and is under the direction of the board of commissioners of State contracts. The amount is limited to $\$ 5,000$ annually. The general size of the volume, character of paper, size of type, and number of lines to the page are prescribed by law, and are under the supervision of the board of commissioners of State contracts. Recently, however, an appropriation of $\$ 2,500$ per annum has been made to the State geological commission for preparing and engraving illustrations and maps and printing and binding reports, but this is not sufficient to cover the entire cost of the work. Cuts for half-tone and zinc illustrations are furnished by the Survey; they are printed by the State printer. Contracts for lithographed or colored maps are made by the Survey directly with commercial firms, the cost being paid out of Survey funds.

The State geological commission has full control over the distribution of its reports. The mailing list, which includes approximately 5,000 names, is recorded on vertical cards, arranged alphabetically, the subject of special interest to each person being indicated. Thus the cards of those interested in coal can readily be distinguished from those interested in oil or clay. The list is further divided into two main classes, the larger of which includes the names of persons to whom an invitation is sent to remit postage if they desire a particular report. The smaller list includes State officers and legislators, professional exchanges, and the more influential men in the mineral industries, as well as important libraries throughout the country. These receive the reports, post free, as they are issued. As a whole the mailing list includes members 
of scientific, engineering, and industrial socíeties and clubs, operators in the mineral industries, teachers of science, and other persons who from time to time send requests for information.

In order to assist in keeping the mailing list alive notices of new publications are sent out, by "first class" mail, and are therefore forwarded to the addressee if he has changed his residence or returned to the Survey office if undelivered. From time to time, about once in two years, the mailing list is revised by removing from it the names of those who have not returned postage for any of the bulletins issued during that period.

A list of newspapers is kept and press announcements are distributed from time to time.

PRESENT LINES OF IVORK.

INDEPENDENT INVESTIGATIONS.

The Survey is at present engaged in three main lines of work, as follows:

(1) Surveys and reports of an areal and economic character. These apply either to the whole State for a particular mineral or to a particular area for all minerals.

(2) Systematic reports on the geologic formations. These will probably be published in large volumes, comparable to those of the first Geological Survey of the State. Those on which the Survey is now engaged relate to the Mississippian series of the Carboniferous system and the Devonian system.

(3) Educational bulletins. Reports are rapidly being prepared on areas which include important educational centers. They deal chiefly with physiographic and general geology, and some of them include historical contributions. They are amply illustrated and are designed to popularize geology and the work of the Survey with teachers, students, and citizens generally.

COOPERATIVE INVESTIGATIONS.

United States Geological Survey.-Cooperation with the Federal Survey includes topographic and geologic surveys and the collection of statistics.

Formal cooperation for topographic surveys is in effect, the annual expenditure by each Survey being $\$ 10,000$. Less formal cooperation applies to the preparation of drainage maps of overflowed lands. Formerly the drainage maps were prepared entirely at the expense of the State, but for the present biennial period the Federal Survey contributes $\$ 2,500$ and the State $\$ 7,500$. The maps are on a scale of $1: 24,000$ and have a contour interval of 5 feet. Approximately $85645^{\circ}-$ Bull. $465-11-4$ 
500 square miles had been mapped before the beginning of the present fiscal year.

Cooperation is also maintained with the Federal Survey for detailed areal, stratigraphic, and economic geologic surveys. This work has been in progress for about four and a half years, and previous to the last field season 11 quadrangles had been mapped. The survey is accomplished by separate State and Federal parties, who work independently, each Survey employing its own methods. All work, however, is subject to inspection by both Surveys, and the data collected are available to both Surveys. Folios will be published by the Federal Survey and bulletins and miscellaneous reports by both Surveys. Heretofore each Survey has contributed $\$ 2,000$ per annum, but for the present fiscal year each Survey is contributing $\$ 2,500$.

Besides quadrangle mapping, the two surveys one season joined in a regional study of the Illinois coal fields. For parts of several seasons the Federal Survey detailed David White to conduct reconnoissance correlation studies in the State. Cooperation in a small way is also maintained for the collection and study of deep-well records. In this work a State employee acts as special agent for the Federal Survey, each bureau contributing $\$ 300$ annually to the expense.

The collection of statistics of the production of Illinois minerals is carried on in cooperation with the statistical division of the United States Geological Survey.

United States Bureau of Mines.-Informal cooperation with the United States Bureau of Mines in the maintenance of a mine rescue station at Urbana, Ill., has succeeded similar cooperation with the United States Geological Survey, of whose technologic branch the Bureau of Mines is the outgrowth. Under this arrangement two Federal employees have been provided, a demonstrating station has been maintained by the University of Illinois, and office accommo. dations and clerical assistance have been furnished by the State Geological Survey. The latter has also contributed a small part of the salary of the station assistant.

United States Department of Agriculture.-Cooperation with the drainage section of the United States Department of Agriculture was formerly carried on and doubtless will be revived. Under this cooperative arrangement the Federal engineers made reconnoissance maps and drainage plans for the reclamation of overflowed lands along typical.rivers, and the State, in cooperation with the United States Geological Survey, surveyed certain other river bottoms, as mentioned in a previous paragraph.

Other State scientific bureaus.-There is considerable cooperation between the State Geological Survey and several departments of the University of Illinois. From time to time members of the laboratory 
force of the university are employed directly by the Survey. Again, an allotment is made to the cooperating department of the university which furnishes the help required for a specific investigation. To the present time work of this nature has been devoted chiefly to chemical research on coal and to practical tests of the clays of the State.

At present the State Geological Survey and the Internal Improvement Commission have a cooperative arrangement for drainage investigations in Illinois. The Survey provides large-scale drainage maps, previously described, and the Internal Improvement Commission makes the necessary engineering studies on which to base plans for the reclamation of flooded lands. The commission also bears the expense of maintaining numerous gaging stations along the rivers which are under investigation.

In the past there has been cooperation between the State Geological Survey and the State Water Survey in the collection and analysis of representative ground waters of the State, the results of which were incorporated in a volume on the composition of Illinois waters. In this study the engineering experiment station of the University of Illinois and the United States Geological Survey also participated.

There has also been cooperation with the State highway engineer in the study of road materials and the selection of sites for State quarries. Doubtless work of this nature will be resumed from time to time, as appropriations permit. Cooperation with the new department of mining at the University of Illinois, in a study of coal mining in Illinois, is in contemplation.

\section{INDIANA.}

\section{HISTORICAL SKETCH. $a$}

The Department of Geology and Natural Resources of Indiana was evolved from perhaps three antecedent State bureaus. The first of these was the State Board of Agriculture, which had to do almost entirely with the science and art of agriculture as carried on in the State. The work at this time, more than 60 years ago, was done by reports on agricultural conditions from individual counties and by addresses by prominent educators or those well rersed in the science of agriculture. Later the Board of Agriculture was enlarged by the addition of a Bureau of Statistics. Hence, in addition to agricultural research, statistics on agriculture, manufacturing, schools, and business were compiled and included in the annual report of the Bureau of Agriculture and Statistics. Still later, partial geologic surreys had been made that attracted the attention of the officials of the State, and the Department of Geological Surrey was added to the Bureau of Agriculture and Statistics. As population increased and work of these various branches increased, the necessity of a separate department of geology and natural resources became imperative, and in accordance with this demand the general assembly of 1881 enacted a law establishing the Department of Geology and Natural History for the State of

${ }^{a}$ Letter from Edward Barrett, State geologist, 
Indiana. The purpose of this bureau was to continue the geologic and scientific survey of the State, to discover and develop the State's natural resources, and to disseminate such information among the people. Under the law of 1881 the governor appointed a competent and suitable person to be State geologist, with the power to call to his assistance such help as he deemed necessary, but he was limited in the expenditure of money for this help to the amount authorized by the general assembly. The geologist's term of office was four years, and he might be removed by the governor for cause. His compensation was $\$ 1,800$ per year. The geological department was established in the State house in Indianapolis, and the care of the State museum was a part of the geologist's duty. He was required to make an annual report to the governor concerning his labors and discoveries, and all scientific information was to be compiled in the form of an annual report, of which 5,000 copies were to be issued. An appropriation of $\$ 5,000$ annually was made, from which the salary of the geolo. gist and his assistants and all expenses of the Department were to be paid, and any unexpended balance should be returned to the State treasury. The work of the Board of Agriculture was carried on as a separate branch of the State administration, and a Bureau of Statistics was established as a separate branch also, with enlarged powers and duties.

\section{PRESENT SURVEY.}

LEGAL DESIGNATION AND DATE OF ORgANIZATION.

The present organization is known as the Department of Geology and Natural Resources; it was organized in 1881. A later law, enacted in 1907, changed the State geologist's salary to $\$ 3,000$.

\section{ORGANIZATION.}

The governing board and the executive officer are the State geologist, who is elected by the people for a term of four years, at : salary of $\$ 3,000$ a year and traveling expenses. His entire time is devoted to the duties of the Department of Geology and Natural Resources. The present incumbent is Edward Barrett, who was elected November 8, 1910, and entered upon his term of office January $1,1911$.

The subordinates include one stenographer, one custodian, two chemists, two hydrographic engineers, and six field assistants on the soil survey. The stenographer and custodian are employed by the year; the term of service of field assistants is indefinite. All are appointed by the State geologist. The salaries range from $\$ 60$ to $\$ 100$ a month.

In hydrographic and soil surveys college professors and students are employed.

\section{APPROPRIATIONS.}

Appropriations are made by the State legislature biennially. Unexpended balances are returned to the State treasury immediately after the close of the fiscal year, September 30. The annual appro- 
priation for office expenses and pay of field assistants is $\$ 3,800$, disbursed as follows:

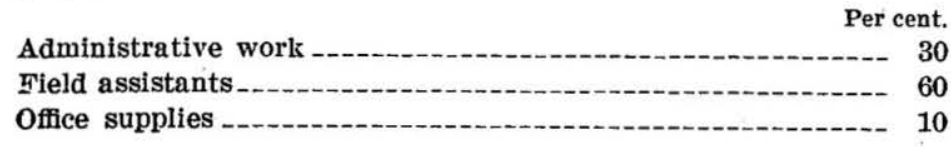

PUBLICATIONS.

The publications consist of a series of annual reports which vary in size from 500 to 1,000 pages. The size of the editions is 5,000 copies. The reports are sent out by mail and express, free of cost to the recipient.

The annual cost of printing reports is from $\$ 3,000$ to $\$ 4,000$, which comes from the general fund. The State geologist has full control of the printing of maps, reports, and illustrations and of the distribution of reports. Reports are sent to colleges, libraries, schools, and educators, to county auditors for distribution, and incidentally to persons who make application for copies.

PRESENT LINES OF WORK.

The Department is at present engaged in a hydrographic survey of rivers and a soil survey of the State by counties. Cooperation with other organizations is not maintained.

\section{IOWA.}

\section{PREVIOUS SURVEYS.}

The first geologic work in Iowa was that of Dr. David Dale Owen, who in the autumn of 1839 surveyed parts of Iowa, Wisconsin, and Illinois, under the direction of the United States Land Office, in accordance with congressional instructions. It was intended primarily to determine the value of the mineral (lead-bearing) lands centering about Dubuque, Platteville, and Galena. However, the actual accomplishment was considerably broader than this, as Owen attacked problems relating to the stratigraphy and paleontology of the district as well as those of a purely economic nature. For skillful organization and rapidity and thoroughness of execution this survey has probably never been excelled, when all the limitations are considered.

In 1847 the United States Treasury Department sent Dr. Owen into the Mississippi Valley, to make a reconnoissance of the Chippewa land district, lying chiefly in Wisconsin but including also that part of northeastern Iowa lying north of the area already surveyed by Owen, as well as a portion of southeastern Minnesota. Dr. Owen's 
time was again limited, only the summer and autumn of 1847 being devoted to field work. Like his previous survey, this survey also shows his marvelous ability for accomplishing a great amount of work in a brief space of time.

$\mathrm{He}$ devoted considerable attention to the lead deposits and their associated rocks and also made extended studies of the geologic formations of the territory.

The results of these two surveys were published as congressional documents, in single octavo volumes, each accompanied by a map and by colored sections and plates.

On the completion of these preliminary surveys Owen was instructed to make a survey of the Northwest Territory. This time his work covered the States of Wisconsin, Iowa, and parts of Minnesota and included some studies of vertebrate fossils from the badlands of Nebraska. The manuscript of his final report was submitted in 1851 and published in 1852. It consisted of a large quarto volume, with 15 plates of fossils, 19 geologic sections, and a geologic map. As with his previous investigations his commission terminated with the submission of his report.

The illustrations for all of Owen's reports were largely reproduced from his own drawings, and for accuracy of detail and beauty of exe: cution these have rarely been equaled.

The next geologic work in Iowa was initiated by the State itself, when in 1855 it authorized the organization of a State Geological Survey. James Hall was appointed State geologist. He carried on the work from 1855 to 1858 and published a report in one volume bound in two parts. The first part dealt with the physiography and geology of the eastern part of the State, and the second part treated the paleontology of the same district. Previous to the completion of this report Hall published, at the end of the year 1856, a small report of progress. In this survey Hall was assisted by J. D. Whitney, A. H. Worthen, B. F. Meek, and R. P. Whitfield, men who later became widely known for their contributions to geologic knowledge. The organization was discontinued by legislative enactment in 1859 .

In 1866 the legislature passed "An act providing for the completion of the geological survey of the State of Iowa," and appointed Charles A. White State geologist for a term of two years. Dr. White spent the years of 1866 and 1867 mainly in an examination of the southern and southwestern parts of Iowa and in a study of the coal fields of the State. At the close of 1867 the first and second annual reports were submitted, together with a number of popular letters which had been written for the newspapers. The next general assembly, in 1868 , required the survey to be completed by January $1,1870$. Under this act a survey of the northwestern part of the State was made, and a report was prepared and presented to the general as- 
sembly in 1870 . This report dealt with the physical-geography, surface geology, and general geology of the region, the method of treatment being a detailed discussion by counties; also with the mineralogy, lithology, and chemistry of the economic products of the State. The report was ordered printed in two royal octavo volumes. As no provision was made for the continuance of the work the survey ceased to exist. Dr. White's assistants were T. S. Parvin, O. H. St. John, and Rush Emery.

\section{PRESENT SURVEY.}

LEGAL DESIGNATION AND DATE OF ORGANIZATION.

The present organization is entitled the Iowa Geological Survey; it was organized in 1892 .

\section{SUMMARY OF LAWS.}

The Survey is under the direction of the geological board, consisting of the governor, the State auditor, and the presidents of the State University, the Agricultural College, and the Iowa Academy of Sciences. The board appoints the State geologist and his assistants. The State geologist is directed to make a complete survey of the natural resources of the State in all their economic and scientific aspects. $\mathrm{He}$ is to prepare detailed maps and reports of counties and districts as fast as their survey is completed, and the results of any special investigations may be published whenever the information obtained warrants it. $\mathrm{He}$ is to cooperate with the United States Geological Survey and with adjoining State surveys in the making of topographic maps and in the study of the geologic problems of the State. He is to present to the board before the 1st of January of each year a report of the work of the preceding year, together with such minor reports and papers as may be considered desirable for publication.

The annual reports, together with such other special reports as may be ordered printed, are published by the State, but the distribution of the entire edition is left to the State geologist.

The expenses of the board and of the members of the Survey staff are paid from the Survey appropriation, which is $\$ 8,000$ annually. Postage, stationery, and office expenses are paid by the State out of funds set apart for that purpose, as are also the cost of printing, binding, and distributing the reports of the Survey.

ORGANIZATION.

The Survey is under the control of the geological board. The five members of this board serve ex officio, and their terms of office are dependent on the length of term of the positions by virtue of which 
they become members of the board. They receive no compensation for their services but are reimbursed for actual expenses incurred in attending the meetings of the board.

The title of the executive officer is State geologist. He is appointed by the geological board and holds office at its pleasure. The present incumbent is Samuel Calvin. He was appointed at the time of the organization of the Survey, in 1892, and served until July 1, 1904. He was reappointed in April, 1906, and has held the position until the present time. Dr. Calvin is at the head of the department of geology at the State University of Iowa. He devotes one-third of his time to Survey work. The compensation of the State geologist is fixed by the geological board and is at present $\$ 900$ per annum.

The Survey employs two clerical assistants, both chosen by the State geologist. One is stationed in the office at Des Moines and is secretary to the geological board; the other is a temporary assistant and is chosen from the student body of the State University. Both serve at the pleasure of the State geologist. The salary of the secretary to the board is $\$ 1,100$ per annum. This is paid by the State, from the clerk fund, and does not come out of the Survey's appropriation. The temporary clerk receives $\$ 10$ a month.

The geologic assistants include an assistant State geologist and from 8 to 10 special assistants. The latter are college instructors or advanced college students. The assistants are appointed by the geological board, on the recommendation of the State geologist, and serve at the discretion of the board. For surveying a county and preparing a report an assistant receives $\$ 150$; for work of other classes a monthly salary is paid, ranging from $\$ 60$ to $\$ 100$. The assistant State geologist is located at Des Moines. His salary is fixed by the geological board at $\$ 1,500$ per annum.

\section{APPROPRIATIONS.}

The appropriations of the Survey are continuing. They hold over from year to year without specific legislative action. They are not contingent on cooperation with the United States Geological Survey or other State surveys, although the amount of the appropriation was increased in order to permit such cooperation.

Unexpended balances revert to the State treasury at the close of the fiscal year.

The annual appropriation is $\$ 8,000$. The objects, so far as specified by law, are a survey of the natural resources of the State, in all their economic and scientific aspects, also cooperation with the Federal and other State surveys in the making of topographic maps and the study of geologic problems common to the States. The amount which may be spent in cooperative work is not fixed by law, but by the rule of the geological board the annual expenditures for 
topographic work in cooperation with the United States Geological Survey has been fixed at $\$ 1,750$ per annum.

During the fiscal year 1909 to 1910 the Survey expenses were divided about as follows:

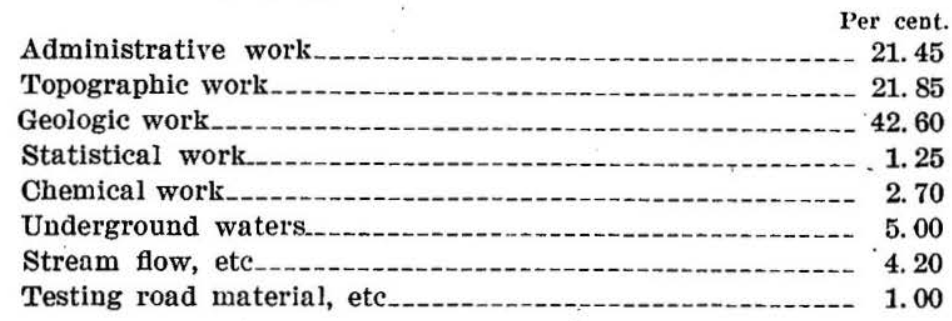

PUBLICATIONS.

The publications of the Survey comprise annual reports, supplementary reports, bulletins, and maps. Of the annual reports 17 have been issued and the eighteenth is in press. The edition is limited by statute to 3,000 copies, 2,200 of which are bound in cloth, 300 in paper, and the remaining 500 are broken into the separate papers. Three supplementary reports have been issued, also in editions of 3,000 copies. Three bulletins have been published, but there is no limit set by law to the size of the edition. Of Bulletin 1, 3,000 copies were printed; of Bulletin 2, 5,000 copies; and of Bulletin 3, 1,000 copies. In addition to the maps which are bound in the reports, one large wall map of Iowa, scale 8 miles to the inch, has been published, the edition being 5,000 copies.

The publications are usually distributed free to citizens of the State. When copies are sold the actual cost of publication is charged. Transportation charges are usually asked of persons outside the State. The income from these sources, however, is not large. In 1909 it amounted to $\$ 29$; in 1910 to about $\$ 65$. All funds received are turned into the State treasury.

The cost of publication of the last five annual reports, including printing, binding, maps, and engravings, has varied from $\$ 1,492$ to $\$ 4,062$, the average being $\$ 2,927$. The cost is paid by the State, out of funds set aside for that purpose.

The reports of the Survey, as well as of all other departments of the State, are printed by the State printer and bound by the State binder. The style of the report was determined by the Survey at the time of its organization and has been kept uniform ever since. There is no restriction as to the number of pages in the reports. Paper is chosen by the executive council of the State. The Survey is given a better quality of paper than most of the State departments, in order that the halftone illustrations may be printed in the body of the text. 
The illustrations are selected by the Survey, but are subject to the approval of the executive council. The zinc plates and halftones used are made by a firm which has a contract with the State for all such work. All illustrations, except lithographed work, whether in the body of the text or separate, are printed by the State printer. There is no restriction upon the contents of the reports, except that they must be approved by the governor.

Lithographed maps are made under contract. Specifications are drawn by the Survey and the contract is awarded by the executive council.

The law gives the State geologist full control over the distribution of the reports. There is a rule of the geological board, however, that when the number of copies of a report has been reduced to 300 a price shall be charged for all future copies sent out. The executive council also holds in reserve 100 copies of each report and this number can not be drawn upon except by permission of the council.

The mailing list comprises geologists and persons interested in geology, both in Iowa and in other States, as well as in many foreign countries; most of the State geological surveys and many other leading scientific organizations of the United States and foreign countries; the public schools and public libraries of Iowa; numerous public libraries outside the State; and the schools and other institutions controlled directly by the State, as well as those under private or denominational management. In addition copies are sent to the various officers and departments of the State government. The list is kept alive by the requests of interested persons and organizations to be included, by supervision of the State geologist, and by requests from this Survey for exchanges.

\section{PRESENT LINES OF WORK.}

Independent investigations.-The Survey is carrying on several lines of work, which may be specified as follows: (a) Study of the areal geology of the State by counties. The State geologist is also preparing a report covering the areal geology of the State as a whole, and the assistant State geologist is preparing a similar report on the physiography of the State. (b) Investigation of the economic geology of the State by subjects. At present work is being prosecuted on road materials, concrete materials, and water powers of the State.

(c) Investigation of underground water resources and collection of well data. (d) Study of special problems, including, at present, the loess deposits of Iowa and neighboring States and the distribution of the drift sheets of the State.

Cooperation with the United, States Geological Survey.-The State Survey is cooperating with the Federal Survey in topographic map- 
ping and in the collection of mineral statistics. In the topographic mapping the State and Federal surveys allot equal sums for the work. The Federal Survey pays the salaries of permanent field employees, and the State Survey pays all field expenses and salaries of temporary employees. Thus far three quadrangles have been mapped and work on a fourth will be begun during the present season. All mapping is on the scale of $1: 62,500$. In the collection of mineral statistics, blanks are sent to producers by the Federal Survey and the State Survey looks after delinquents. Duplicate copies of the individual reports are sent to the State Survey, and the data are compiled and the results published as a part of its annual report.

KANSAS.

PREVIOUS SURVEYS.

FIRST GEOLOGICAL SURVEY.

The first State Geological Survey of Kansas was authorized by an act of the State legislature in 1864 . Section 1 of the act provided that the governor, with the consent of the senate, should appoint a State geologist, whose term of office should begin on March 1, 1864, and end March 1, 1865. Section 2 provided that the State geologist should equip a proper laboratory, should procure necessary assistants, and should proceed to classify the rocks and soils of each county in the State; that he should visit and analyze the salt springs already discovered, and use due diligence in discovering others; and that he should investigate the coal formations and other mineral deposits of the State by the various appliances known to the science of geology and mineralogy. It further provided that he should immediately report any discoveries of valuable deposits or other materials of importance to the State, and that he should prepare and deposit with the State librarian a cabinet of correctly labeled geologic specimens illustrating the geology of the State. Section 3 provided that during the month of November, 1864, the State geologist should deliver to the governor his annual report, which should contain a complete exposition of the work accomplished. Section 4 provided that the State auditor should draw State warrants for the expenses of the Survey in such sums as in his opinion were necessary, not, however, to exceed $\$ 3,500$ during the year. Section 5 provided that the State geologist should execute a bond to the State in the sum of $\$ 5,000$, guaranteeing the faithful and proper performance of the duties of the office, and that he should take the ordinary oath of office. Section 6 provided that the governor should have power to remove the State geologist for incapacity or neglect of duty and to 
fill any and all vacancies that might occur by death or otherwise. Section 7 provided that this act should be in force from and after its proper publication in the State paper. The act was approved by Governor Thomas Carney on February 10, 1864.

Under the foregoing act the governor appointed Prof. B. F. Mudge State geologist, Maj. Frederick Hawn assistant geologist, Prof. G. C. Swallow paleontologist, Tiffin Sink chemist and meteorologist, and C. A. Logan botanist.

The first annual report of the Survey appeared in 1866 and consisted of a pamphlet of 56 pages.

SECOND GEOLOGICAL SURVEY.

In 1865 the legislature passed a new act regarding the State Survey. Section 1 provided that the governor, with the consent of the senate, should appoint the State geologist, whose term of service should begin on the 1st day of March, 1865. No time limit was added to this appointment. Section 2 provided that $\$ 7,500$ should be appropriated for the prosecution of the work during that year. Section 3 provided for the manner of payment by the State auditor, and section 4 provided that the act should take effect and be in force from the date of proper publication. This act was approved by Governor S. J. Crawford on February 11, 1865. Under it the governor appointed Prof. G. C. Swallow State geologist, and all the assistants who served during the preceding year were continued. Prof. Mudge, however, was not reappointed to any position on the Survey.

The State geologist of this Survey submitted a report consisting of 162 pages, which was issued in pamphlet form in 1866 .

The succeeding legislature failed to make any appropriation for the bureau, so that the second Geological Survey continued during one year only.

At different times between 1866 and 1893 various citizens tried to revive the State Geological Survey, but each time without success. During that interval a bill was introduced for this purpose at almost every session of the legislature, showing that a very considerable interest in the matter was kept alive throughout the State

\section{PRESENT SURVEY.}

IEGAL DESIGNATION AND DATE OF ORGANIZATION.

The present Survey is known as the State Geological Survey of Kansas; it was organized in 1895 , under the law of 1889 , which was amended in 1907. 
The State legislatire which met in 1889 in a measure remodeled the laws governing the State University, and specified that one of the functions of the university was to organize and conduct a State Geological Survey. Preliminary work on the Survey was begun in 1893 by Profs. Erasmus Haworth and S. W. Williston and their advanced students. By 1895 sufficient progress had been made to warrant the regents in formally organizing a State Geological Survey, which they did in accordance with the law of 1889 already mentioned.

The work of the Survey was for a number of years continued under the name, University Geological Survey of Kansas. At every session of the legislature a direct appropriation was made for it by a bill independent of the general university appropriation bill.

To meet the objection of certain members of the legislature that the Survey was not established on a substantial legislative act, the legislature of 1907 passed a special act (chapter 395) providing for the permanent continuance of the Survey, for the officers of the same, and for the printing of its reports. Section 2 of this bill provides that the chancellor of the University of Kansas shall be ex officio director of the Survey and that the immediate work of the Survey shall be directed by the State geologist, who shall be appointed by the chancellor of the university and shall be a member of the department of geology of that institution. It also provides that he shall prepare and submit to the chancellor for publication all reports of the Survey. Section 3 provides that the State geologist shall prepare for publication and submit to the chancellor from time to time such reports on the geology of the State as he and the chancellor may consider advisable. Section 4 provides that the State printing board shall have printed 5,000 copies of each of the reports provided for in section 3 and makes further provision for the distribution of the reports. This act was approved March 9, 1907, and was officially published and became a law March 14, 1907.

\section{ORGANIZATION.}

The form of organization is outlined under the foregoing "Summary of laws." The compensation of officers and other employees is not mentioned in the law, all matters of that nature being left to the board of regents.

'The chancellor of the University of Kansas is ex officio director of the Survey. The present chancellor is Frank Strong. Erasmus Haworth, at the head of the geological department of the university, is State geologist. He devotes about half of his time to the work of the Survey and the remainder to his university duties. 
The clerical work of the Survey is performed by the regular clerical force of the university, except the stenographic assistance, which is rendered by a special stenographer.

The number of geologic assistants varies from four to twelve. They usually are advanced students of the university; most of them work without other compensation than their field expenses and the credits which are given them toward degrees in the university. The chemical work is done in part by the chemical department of the university and in part by a special chemist employed for special purposes.

The Survey has done no topographic work. During the summers of 1895 and 1896 the entire force of the Survey was employed in investigating ground-water conditions in the western part of the State. Since then it has given little attention to the water resources.

\section{APPROPRIATIONS.}

Appropriations for the Survey were made by special acts of the legislature until after the passage of the act of 1907. Since the passage of that act the appropriations have been included in the general university budget. They are biennial in duration, as the State constitution prohibits the legislature from making continuous appropriations. Unexpended balances lapse into the State treasury July 1 of each year.

The annual appropriations for actual expenses in the field and laboratory and for the services of a stenographer have varied from $\$ 1,500$ to $\$ 3,000$ annually. All other clerical work, all printing, all office accommodations, power, light, heat, stationery, library facilities, etc., are provided by the university.

The annual appropriation is not divided into several parts. It is the practice of the Survey to undertake a definite piece of work and devote practically all appropriations to it until it is completed.

PUBLICATIONS.

The publications of the Survey comprise nine volumes, averaging about 500 pages each. Five of these are devoted to economic geology. Of the other four, one relates to the general stratigraphy of eastern Kansas, one to the general geology of western Kansas, and two to the Cretaceous and Carboniferous paleontology of the State.

The size of the edition is usually 5,000 copies. The volumes are bound in cloth.

From 1897 to 1903 , inclusive, the Survey also issied a series of pamphlets on the mineral resources of Kansas.

The average annual cost of printing probably approximates $\$ 2,500$ a year. 
All printing must be done under the direction of the State printer, who may, if he desires, order any part of it done at other printing offices.

By law 750 copies of each report are delivered to the State legislators, 60 copies are delivered to the State Historical Society, and other copies are used in a world-wide exchange of publications. The citizens of the State are supplied with reports as long as they last, on the payment of postage.

The only mailing list that is kept is the exchange list.

PRESENT LINES OF WORK.

Independent surveys. - The Survey is at present directing its energies to a study of the clays of the State. The investigation preceding this was on coal-mine explosions, the report of which is nearly ready for the printer.

Cooperation with United States Geological Survey.-Cooperation with the Federal Survey is carried on in the collection of statistics of mineral production.

Other cooperative work.-Recently cooperation to a small extent has been had with two outside organizations in a study of Permian paleontology.

\section{MAINE.}

\section{PREVIOUS SURVEYS.}

By act of the State legislature dated March 28, 1836, a geologic survey of the State of Maine was authorized. Charles T. Jackson was appointed State geologist. The investigation was continued during the following three years. The published results, considering the difficulties of transportation at that time and the nonexistence of accurate maps, are interesting. They include three annual reports; entitled "Geology of the State of Maine," and dated 1837, 1838, and 1839; a report entitled "Report of an exploration and survey of the territory on the Aroostook River;" and a report entitled "Second annual report of the geology of the public lands belonging to the two States of Maine and Massachusetts."

In 1861 and 1862 a detailed survey and report of the natural history and geology of the State was made by C. H. Hitchcock, geologist, and Ezekiel Holmes, naturalist. Reports on the zoology and botany of the State were included, but the most interesting and detailed reports treated of the geologic resources.

In 1867 a hydrographic survey of the State was authorized by the legislature, the work being intrusted to Walter Wells. His report on the water resources of the State and the location of water-power sites is considered an authority even to the present day. A large por- 
tion of the report consists of the description, by towns, of developed water powers and undeveloped power possibilities. The fact that there are more than 1,500 lakes in Maine, or 1 lake to each 20 square miles of territory, will give an idea of the magnitude of hydrographic surveys in the State.

\section{PRESENT SURVEYS.}

TITLES AND DATES OF ORGANIZATION.

At the present time there are two organizations in the State working along geologic and hydrographic lines. They are known as the Maine State Survey Commission and the Maine State Water Storage Commission. The first organization was authorized by act of the State legislature dated March 16,1899. Its powers were subsequently amended and enlarged by an act approved March 23, 1905 . The creation of the State Water Storage Commission was authorized by act, of the legislature dated April 2, 1909.

\section{SUMMARY OF I.AWS.}

The following are the laws creating the two commissions described above:

An act to authorize a topographic survey of the State in cooperation with the United States Geological Survey.

[Laws of Malne, 1899, clap. 99.]

Secrion 1. That the goveruor be, and is hereby, anthorized to appoint a commission, to consist of three citizens of this State, qualified by education and experience for such service, to confer with the Director or the representative of the United States Geological Survey and to accept its cooperation with this state in the preparation and completion of a contour topographic survey and map of this State, which is hereby authorized to be made. Said commission shall serve without pay, but all its necessary expenses shall be approved by the governor and paid out of the State treasury. Sald commission shall have power to arrange with the Director or representative of the United States Geological Survey concerning this survey and nap, its scale, method of execution, form, and all details of the work, in behalf of this State. ancl may accept or reject the work executed by the United States Geological Survey. And it is hereby provided that said map siall accurately show the outlines of all towuships, counties, and extensive wooded areas in this State, as existing on the ground at the time of the execution of these surveys; the location of all roads, railroads, streams, canals, lakes, and rivers, and the location and height of all dams; and shall show by contour lines the elevation and depression of the surface of the country.

SEc. 2. Said commission may expend for the prosecution of this survey a sum equal to that to be expended upon the same work by the United States Geological Survey, not to exceed at the rate of $\$ 2,500$ annually, for the years 1899 and 1900, and the governor is hereby authorized to draw his orders on the State treasury for such portions thereof as may be required from time to time, 
from moneys not otherwise appropriated, upon receipt of vouchers signed by not less than two members of the commission.

SEc. 3. For the purpose of making the surveys hereinbefore provided for, it shall be lawful for the persons employed in making the same to enter upon all lands within the boundaries of this State; but this act shall not be construed as authorizing any unnecessary interference with private rights.

Approved March 16, 1899.

An act to amend an act authorizing a topographic survey of the State.

[Laws of Maine, 1905, chap. 144.]

SEcrion 1. The commission directed with the execution of this work shall hereafter be known as the State Survey Commission, the chairman of which shall be the State geologist, and shall include in its work the topographic, hydrographic, and geological surveys of the State as provided by acts and resolves of preceding legislatures.

SEC. 2. Said commission is authorized to distribute without charge, for the use of public libraries, and for other educational purposes, such maps and reports relating to the work of the commission as may become available.

SEc. 3. Said commission shall make report, biennially, to the governor and council, showing work accomplished, together with a detailed account of expenditures, and shall be authorized to print and distribute, from time to time, such report and bulletins as may in the judgment of said commissioners be immediately useful and profitable to the people of the State, the expense thereof to be chargeable to, and paid out of, the appropriation herein made.

SEc. 4. Said commission shall be reimbursed for all necessary expenses as approved by the governor and council, and, in addition, the chairman shall be paid an annual salary of $\$ 600$ and the remaining members of the commission each $\$ 300$ annually.

SEc. 5. It is further provided that there shall be and hereby is appropriated for the work of said commission, including all expenses, the sum of $\$ 10,000$ for the year 1905 and a like sum for the year 1906.

SEc. 6. All acts and parts of acts inconsistent herewith are hereby repealed.

Approved March 23, 1905.

An act to create a State Water Storage Commission.

[Laws of Maine, 1909, chap. 212.]

Section 1. The governor, with the advice and consent of the council, is authorized to appoint three citizens of the State, who, together with the governor and the State land agent, shall constitute a commission to be known as the State Water Storage Commission, of which the governor shall be chairman. As members of said commission they shall receive no salaries but shall be paid their actual and necessary expenses incurred in the performance of their duties and may employ a competent engineer. The office of the commission shall be at the State house in the city of Augusta. The commission may appoint a secretary who shall be paid a salary not to exceed $\$ 600$ per annum, who shall work in conjunction with the land agent.

SEC. 2. The commission shall proceed at once to collect information relating to the water powers of the State, the flow of rivers and their drainage area, the location, nature and size of the lakes and ponds in the State and their respective value and capacity as storage reservoirs, with a view to conserving and increasing the capacity of the water powers of the State.

$85645^{\circ}-$ Bull. $465-11-5$ 
SEc. 3. The commission shall, so far as possible, work in conjunction with the State Survey Commission, and with such State Survey Commission join with the United States Geological Survey in making a topographic survey of the State in so far as it relates to the collection of data bearing on the water powers and water-storage reservoirs of the State. The State Survey Commission shall place at the disposal of the State Water Storage Commission all information, and copies of reports, maps, and plans collected by them and bearing on the hydrography of the State.

SEC. 4. Every person, firm, or corporation, before commencing the erection of a dam for the purpose of developing any water power in this State, or the creation or improvement of a water-storage basin or reservoir for the purpose of controlling the waters of any of the lakes or rivers of the State, shall file with said commission for its information and use copies of plans for the construction of any such dam or storage basin or reservoir and a statement giving the location, height, and nature of the proposed dam and appurtenant structures and the estimated power to be developed thereby, and in case a dam is to be constructed solely for the purpose of water storage and not for the development of a water power at its site, plans and statements shall be filed with the commission showing the extent of the land to be flowed, the estimated number of cubic feet of water that may be stored, and the estimated effect upon the llow of the stream or streams to be affected thereby. Every person, firm, or corporation shall, as soon as practical after this act takes effect, file similar plans, reports, and estimates in relation to any dam or storage basin or reservoir then in process of construction by them.

Sec. 5. The commission shall present to the legislature on or before the 15th day of January, in the year of our Lord 1911, a report showing the progress made in its investigations to such an extent before January 1 , in the year of our Lord 1911, as will enable it to present in its report a comprehensive and practical plan for the improvement and creation of such water-storage basins and reservoirs as will tend to develop and conserve the water powers of the State. The commission shall also report so far as its investigation will permit on the present development of the water powers in the State with reference to the general plan proposed, so that the legislature may have before it a comprehensive summary of the possibilities that lie in the development of the water powers in the State as a natural resource and the necessary steps that should be taken by the State to further conserve and increase them.

SEc. 6. So far as any proposed plan derised by the commission for the improvement and increase of water-storage basins or reservoirs shall include the construction of a dam or dams upon or at the headwaters of any river or watercourse, the commission shall ascertain and report as nearly as may be-the water-storage capacity in cubic feet of the reservoir to be created, the recorded rainfall on the watershed above such proposed dam, and the maximum, minimum, and average flow of water per second in cubic feet during each month in the year in said river or watercourse. They shall as nearly as practicable estimate the increased power that would be developed by such proposed dam in the rivers or streams to be affected thereby.

SEc. 8. The commission shall ascertain what townships or parts of townshins of land can be purchased by the State and the cost thereof, with all the necessary data for a correct understanding of their value as a forest reserve or for conserving the water powers of the State, or for reforestation, and shall further investigate the question of denuded, burnt over, or barren lands in the State, their extent and value, with a view to their purchase by the State for reforestation. 
SEc. 9. The sum of $\$ 5,000$ for the year 1909 and $\$ 5,000$ for the year 1910 , or so much thereof as may be necessary, is hereby appropriated out of any fund in the treasury of the State, not otherwise appropriated, to carry out the provisions of this act.

Approved, April 2, 1909.

URGANIZATION.

The State Survey Commission is composed of three members, appointed by the governor, with no fixed term of office. The compensation of these commissioners is noted in the abstract of laws given above. The chairman of the commission, who is by law also State geologist, is C. Vey Holman.

The State Water Storage Commission is composed of five members, including the governor, the State land agent, and three citizens of the State appointed by the governor. As members of this commission they receive no salaries but are paid the actual and necessary expenses incurred in the performance of their duties.

By an agreement dated December 1, 1909, between the Director of the United States Geological Survey, the chairman of the State Survey Commission, and the chairman of the State Water Storage Commission, the work of the three surveys in the State is brought under one direction. This agreement provides for a cooperative survey of the natural resources of Maine, including the continuation of topographic mapping; a determination of the amount and availability of water resources; their present development, and the best methods of their future utilization, and the determination of geologic resources.

Under this agreement the executive officer is to be a duly appointed employee of the United States Geological Survey, with the title of district engineer. The present incumbent is Cyrus C. Babb, who was appointed by the Director of the United States Geological Survey December 8, 1909, the appointment being approved by the governor, Hon. Bert M. Fernald. Under the law the district engineer is required to establish his headquarters at the State capitol in Augusta, Me. His salary, which is annual, is determined by his appointment on the United States Geological Survey through the United States Civil Service Commission, and under the terms of the agreement above described it may be paid from any of the allotments of the three organizations which are parties thereto.

Assistants are either appointed by the executive officer or detailed from the United States Geological Survey and are classed as clerical, geologic, engineering, and topographic. One clerk only is employed, the appointment being made by the district engineer, and the compensation being from $\$ 40$ to $\$ 50$ a month. The geologic assistants are detailed by the Director of the United States Geological Survey as 
required, the compensation being as determined by civil-service appointment. Those engaged in hydrographic surveys include the following: One assistant engineer, detailed from the United States Geological Survey on recommendation of the district engineer, compensation $\$ 1,600$ to $\$ 1,800$ per annum; two field assistants, appointed by the district engineer, compensation $\$ 60$ to $\$ 75$ a month; two junior topographers, detailed by the Director of the United States Geological Survey, salaries about $\$ 90$ a month; one field assistant, either the professor of civil engineering in the State University or one of the assistant professors, compensation $\$ 75$ to $\$ 150$ a month; and the necessary field laborers. The topographers and assistant topographers engaged in the topographic surveys are detailed from the topographic branch of the United States Geological Survey, and their compensation is from $\$ 75$ to $\$ 200$ a month.

\section{APPROPRIATIONS.}

The appropriations of the State organizations are made biennially, and in general unexpended balances lapse to the State treasury. Under a recent State law appropriations are not available until 90 days after approval of the act by the governor. The old appropriations, however, are in force until the new ones are available. Although the fiscal year ends December 31, the old appropriations usually do not lapse until about July 1. The appropriation of the State Survey Commission is contingent on cooperation with the United States Geological Survey; the appropriation of the State Water Storage Commission is not so restricted.

The annual appropriation for the Survey Commission is $\$ 10,000$ and of the Water Storage Commission $\$ 5,000$. Under the terms of the cooperative agreement of December 1, 1909, the amount available for the current fiscal year, for topographic, geologic, and hydrographic investigations in the State is $\$ 23,000$.

The expenditures, in percentages, are about as follows:

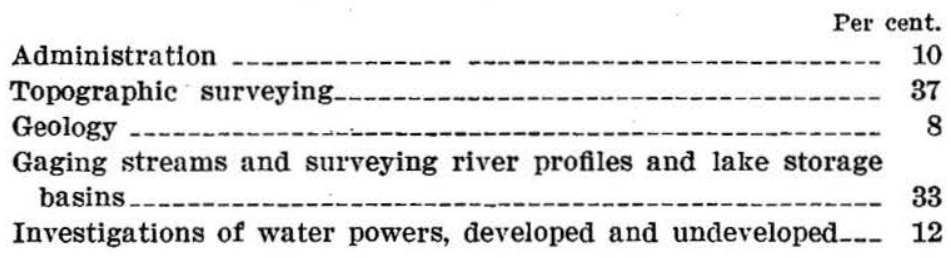

PUBLICATIONS.

The reports of the State Survey Commission are pamphlets of 8 to 12 pages each, giving in condensed form the results of the work during each biennial period. Five such biennial reports have been issued. 
The State Water Storage Commission has not yet made a report. One of the purposes of its creation was to assemble all available data bearing on the water powers and water resources of the State in the files of the different bureaus of the National Government as well as in the State files, and present them in a comprehensive report for the use of the citizens of the State.

The results of the cooperative work of the State Survey Commission and the United States Geological Survey have been published from time to time in the reports of the National Survey. Up to the present time the State organization has expended its money on field work.

PRESENT LINES OF WORK.

The two State commissions are working in cooperation with the United States Geological Survey, as already described. The special lines of investigation are geologic surveys, topographic surveys, and investigations of water resources. The investigations of water resources, which are designed to conserve and increase the water powers of the State, include the collection of information relating to developed and undeveloped water powers, the flow of rivers and their drainage areas, and the location, nature, and size of the lakes and ponds and their value and capacity as storage reservoirs.

\section{MARYLAND.}

\section{PREVIOUS SURVEYS.}

The first Geological Survey of Maryland dates from 1833, when, on March 6 and March 16, resolutions were passed by the general assembly of the State providing for the organization of official scientific work. Under the first resolution the governor and council were authorized to appoint a competent engineer to prepare "a plan and drawing for a complete map of Maryland," and also to make such "further examinations and surveys as may be requisite, for the purpose of exhibiting the prominent geographic and topographic features of the country; and also to collect such statistical information as will be useful and is generally exhibited on modern improved maps." Under the second resolution the governor and council were authorized to appoint a geologist "to act in conjunction with said engineer" and to "make the necessary geological researches and report to the governor and council before the next session of the general assembly, upon the expediency and the probable cost of a geological survey of the State." In accordance with these resolutions J. H. Alexander was appointed engineer and J. T. Ducatel geologist. The result of this preliminary survey formed the basis of a joint report to the general assembly, and on February 25, 1834, an act was passed "for 
making a new and complete map and geological survey of this State," and Messrs. Alexander and Ducatel were again appointed engineer and geologist, respectively.

Maryland was thus the third State to establish an official Geological Survey, being preceded by only Massachusetts and Tennessee, although some beginnings had already been made by South Carolina and North Carolina. To Maryland, however, belongs the credit of being the first to undertake a topographic survey. It was stated at the time that one of the chief objects of establishing the Survey was to secure the cooperation of the Superintendent of the United States Coast and Geodetic Survey. Such a plan was perfected and subsequently carried out, evidently marking the beginning of the Federal and State cooperation in such matters which to-day prevails. Official reports and maps were issued by the Survey annually until 1842, when in February of that year the general assembly abolished the offices of engineer and geologist. A topographic map of the State had been made, on the scale of $1: 200,000$, with 50 -foot contour lines to the east and 100-foot contour lines to the west of Monocacy River. This map, however, was never published, but a manuscript copy still exists. Special maps of certain portions of the State were also prepared, the most detailed being a topographic map of Dorchester, Somerset, and Worcester counties on the scale of $1: 211,200$, with 4 -foot contour lines. The geologic publications of this first Survey consisted chiefly of county geologic reports, which embraced accounts of the physical geography, stratigraphy, mineral resources, and agricultural conditions. The reports were brief, but added much to the existing knowledge of the geology of the State.

No further official geologic work was attempted in Maryland until the general assembly, in March, 1848, authorized the governor to appoint a State agricultural chemist. Although the act authorized an examination of the mineral deposits, no attempt was made to carry out this provision of the act until the appointment of Philip T. Tyson in 1858. Mr. Tyson, who was much interested in geologic problems, published in his first report, which appeared in 1860, a geologic map of the State, on the scale of 12 miles to the inch, which was by far the most complete representation of Maryland's geology that had been attempted up to that time. In this report he dwelt upon the importance of a knowledge of the geologic formations of the State as a basis for the determination of the character of the soils as well as for all industrial operations. To the limestones and marls he gave special attention. In his second and last report, issued in 1862, just prior to the repeal of the act establishing the office of State agricultural chemist, he devoted much more attention to the mineral resources of the State than in his earlier report. 
No further attempt at a systematic investigation of the geology of the State was made until the organization of the geologic department of Johns Hopkins University, in 1883, when Dr. George H. Williams began his connection with that institution as instructor in mineralogy. Dr. Williams devoted his attention particularly to a study of the crystalline rocks of the central portion of the State. In 1887 Dr. William Bullock Clark was added to the faculty of the university, as instructor in stratigraphic geology and paleontology, and he at once extended the geologic work to a study of the sedimentary formations of the eastern and southern portions of the State. The cooperation of the United States Geological Survey was secured, and Messrs. Williams and Clark were given appointments on the staff of the Federal Survey. Upon the death of Dr. Williams, in 1894, Dr. Edward B. Mathews was appointed to his position. Areal geology and special paleontologic and petrographic studies were continuously pursued until 1896, when the present State Geological Survey was organized, with Dr. Clark as State geologist and Dr. Mathews as assistant State geologist.

\section{PRESENT SURVEY.}

LEGAI, DESIGNATION AND DATE OF ORGANIZATION.

The present organization is designated the State Geological and Economic Survey; it was organized March 19, 1896.

\section{SUMMARY OF LAWS.}

An act to establish a State Geological and Economic Survey, and to make provision for the preparation and publication of reports and maps to illustrate the natural resources of the State, together with the necessary investigations preparatory thereto. ${ }^{a}$

Section 1. Be it enacted by the general assembly of Maryland, That there is hereby established a State Geological and Economic Survey which shall be under the direction of a commission composed of the governor, the comptroller, the president of the Johns Hopkins University, and the president of the Maryland Agricultural College, who shall serve without compensation, but shall be reimbursed for actual expenses incurred in the performance of their official duties; and the said commissioners shall have general charge of the Survey and shall appoint as superintendent of the same a geologist of established reputation, and upon his nomination such assistants and employees as they may deem necessary; and they shall also determine the compensation of all persons employed by the Survey, and may remove them at pleasure.

SEc. 2. And be it enacted, That the Survey shall have for its objects:

1. An examination of the geological formations of the State, with special reference to their economic products, viz, building stones, clays, ores, and other mineral substances.

a Laws of Maryland, 1896, chapter 51. 
2. An examination and classification of the soils and a study of their adaptability to particular crops.

3. An examination of the physical features of the State with reference to their practical bearing upon the occupations of the people.

4. The preparation of special geological and economic maps to illustrate the resources of the State.

5. The preparation of special reports, with necessary illustrations and maps, which shall embrace both a general and detalled description of the geology and natural resources of the State.

6. The consideration of such other scientific and economic questions as in the judgment of the commissioners shall be deemed of value to the people of the State.

SEc. 3. And be it enacted, That the commissioners shall cause to be prepared a report to the legislature before each meeting of the same, showing the progress and condition of the Survey, together with such other information as they may deem necessary and useful or as the legislature may require.

SEc. 4. And be it enacted, That the regular and special reports of the Survey, with proper illustrations aud mans, shall be printed as the commissioners may direct, and that the reports shall be distributed or sold by the said commissioners as the interests of the State and of science demand, and all moneys obtained by the sale of the reports shall be paid into the State treasury.

SEc. 5. And be it enacted, That all material collected, after having served the purposes of the Survey, shall be distributed by the commissioners to the educational institutions in such manner as to be of the greatest advantage to the educational interests of the State; or, if deemed advisable, the whole or a part of such material shall be put on permanent exhibition.

SEc. 6. And be it enacted, That the sum of $\$ 10,000$ annually, or so much thereof as may be necessary, is hereby appropriated out of any funds of the treasury not otherwise appropriated, for the purpose of carrying out the provisions of this act.

SEc. 7. And be it further evacted, That this act shall take effect from the date of its passage.

The foregoing bill was introduced in the house January 9, 1896, was passed by that body February 18, by the senate March 11, and received the signature of the governor March 19.

Two years after the organization of the Survey additional legislation was obtained for the furtherance of topographic surveying and the publication of reports by the enactment of the following:

An act to provide for the making of topographic maps and for the publication of reports of the State Geological and Economic Survey, and to make an appropriation therefor.

[Laws of Maryland, 1898, chapter 129.]

Section 1. Be it enacted by the general assembly of Maryland, That the commission established by the act of the general assembly of Maryland at the session of 1896 , chapter 51 , be, and the same is hereby, authorized to make provision for the completion of the topographic survey of Maryland in such manner as in the opinion of the commission will be of the greatest benefit to the agricultural, industrial, geological, and military requirements of the State of Maryland. 
Sec. 2. And be it further enacted, That the said commission be, and the same is hereby, authorized to publish special reports dealing with the various mineral products and with the natural resources of each county of the State of Maryland.

SEC. 3. And for the purpose of carrying out the provisions of this act be it further enacted, That the sum of $\$ 5,000$ annually, in addition to the amount appropriated by the act of the general assembly of Maryland at the session of 1896, chapter 51, or so much thereof as may be necessary, be, and the same is hereby, appropriated out of any funds in the treasury not otherwise appropriated, and the said amount be drawn from the treasury by the said commission in the same manner as the other funds of the Survey.

SEc. 4. And be it further enacted, That this act shall take effect from the date of its passage.

The foregoing bill was introduced in the senate February 2, was passed by that body February 16, by the house March 17, and received the signature of the governor April 2.

For twelve years, from 1898 to 1910, the State Geological Survey maintained a highway division, but in 1910 the general assembly consolidated that division with a newly organized State Roads Commission. Under the act of 1898 an investigation of the roads and road-building materials of the State was undertaken, a testing laboratory was built, and advice was given by the engineers of the Survey to State, county, and municipal authorities. Under this act $\$ 10,000$ was appropriated annually. In 1904, however, further legislation made available $\$ 400,000$ annually from State and county funds for the construction of roads under the State Geological Survey, and in 1906 and 1908 special appropriations were made to the Survey for the construction of a road between Baltimore and Washington. Altogether about $\$ 2,000,000$ was expended under the auspices of the Survey on road work, and the foundation was laid for the establishment of the present State Roads Commission, which has the expenditure of about $\$ 2,000,000$ annually. Under the terms of the act establishing the Roads Commission, three out of its six members are appointed from the State Geological Survey, one of the three being State geologist. The influence of the Survey is thus being perpetuated, although the highway work is no longer carried on under its direct supervision.

\section{ORGANIZATION.}

The governing board is composed of the governor of the State, Austin L. Crothers; the State comptroller, William B. Claggett; the president of Johns Hopkins University, Ira Remsen; and the president of the Maryland Agricultural College, R. W. Silvester. These are all ex officio appointments. The members of the board receive no compensation beyond their expenses.

The executive officer is the State geologist. The present incumbent is Prof. William Bullock Clark, who has held the office since March 
25,1896 . The State geologist is appointed by the governing board. His term of office is indeterminate. His compensation, which is on a per diem basis, is fixed by the board. Dr. Edward B. Mathews is assistant State geologist.

With the exception of a secretary, shipping clerk, and office boy, all the employees may be classed as geologic, as the topographic, hydrographic, magnetic, agricultural soil, meteorologic, and forestry work of the Survey is carried on in cooperation with other State organizations or with Federal bureaus, and those engaged in the work are for the most part employees of those bureaus.

The geologic assistants consist almost exclusively of instructors and graduate students in geology at Johns Hopkins University. The compensation is entirely on the per diem basis and varies with the ability of the workers to furnish results of value to the Survey. The number employed varies with the season of the year, but from 12 to 15 are annually on the rolls for longer or shorter periods. No civil-service examinations are required, and the appointments are left to the State geologist, subject to the approval of the board.

\section{APPROPRIATIONS.}

The appropriations are continuing and are not contingent on cooperation. All unexpended balances are carried to the next fiscal year and do not lapse to the State treasury. The annual appropriation is $\$ 15,000$. Fully 90 per cent is devoted to geologic and topographic surveys, paleontologic studies, and publication. The remainder is devoted to special investigations. The topographic survey of the State is now nearly completed, and although conducted on behalf of the State, under the direction of the State geologist, the expense has been shared by the highway division of the State Geological Survey, the State Weather Service, and the State Forestry Bureau, of all of which the State geologist has also been the executive officer.

\section{PUBLICATIONS.}

The publications of the present State Survey comprise volumes 1 to 9 of general reports, 3 volumes of systematic geology and paleontology (Eocene, Miocene, and Pliocene-Pleistocene), 6 volumes of county reports (Allegany, Garrett, Cecil, St. Marys, Calvert, and Prince Georges counties), a guide to the State mineral exhibit, 3 State maps (on scales of 8,5 , and 3 miles to the inch), 18 county maps (scale 1 mile to the inch), and a map of Baltimore and vicinity. The size of the edition has varied from 1,500 for the county reports and the volumes of systematic geology and paleontology to 2,500 for the general reports and 5,000 for the guide to the mineral exhibit. The maps are usually published in editions of 5,000 each. 
The cost of printing reports and maps is defrayed from the Survey appropriation and varies widely from year to year. The Survey has full control of all matters connected with the printing of maps and reports. No limitations of any kind exist. The Survey also has full control over the distribution of reports and maps, which are sent to all leading libraries, scientific societies, and many prominent geologists both at home and abroad. An extensive exchange has been established.

\section{PRESENT LINES OF WORK.}

\section{INDEPENDENT INVESTIGATIONS.}

The Survey is engaged independently in a study of the geology of the State, including primarily stratigraphy, paleontology, and mineral resources. The geologic formations are being mapped as fast as the topographic base maps are completed. These are on a scale of 1 mile to the inch. Special monographs dealing with the systematic geology and paleontology of the State are likewise being prepared. In addition to the volumes on the Eocene, Miocene, Pliocene, and Pleistocene already issued, manuscripts are nearly completed for the Devonian, Upper Cretaceous, and Lower Cretaceous. Special economic studies of the building stones, coals, clays, and limestones have already been published and a manuscript on iron ores is now in press.

\section{COOPERATIVE INVESTIGATIONS.}

United States Geological Survey.-The State Geological Survey cooperates with the United States Geological Survey in its topographic work, in certain areal geologic surveys in the central portion of the State, and in the collection of mineral statistics. Special cooperation has also been undertaken in connection with some of the paleontologic studies. Preliminary arrangements have also been made for a study of the swamps adjoining Chesapeake Bay.

Other departments of the National Government.-For many years cooperation has been maintained with the United States Bureau of Soils and the United States Coast and Geodetic Survey. The cooperation with the Soils Bureau has been in the preparation of agricultural soil maps of the several counties, with accompanying descriptive texts, which have been incorporated in the county reports. The cooperation with the United States Coast and Geodetic Survey has been in the establishment of North-South lines at the county seats and in the preparation of reports on the terrestrial magnetism of the State, which have been published in the general reports and the county reports. This work is now being done under the auspices of the Carnegie Institution of Washington. Cooperation was main- 
tained for several years with the United States Forest Service, but this work is now carried on through the medium of the State board of forestry,

Other State geological surveys.-No direct cooperation has been undertaken with other State geological surveys, although close affiliation has been maintained with the surveys of Virginia and North Carolina, especially in the study of the deposits of the Coastal Plain.

Other State scientific bureaus.-Cooperation is maintained with the State Weather Service in the preparation of reports on the climate of the State, which have been issued in the county reports, and with the State Board of Forestry in the preparation of maps and reports on the forests of the various counties.

\section{MICHIGAN.}

\section{PREVIOUS SURVEYS.}

The first State Geological Survey of Michigan was organized in 1837 , the act establishing it carrying an appropriation of $\$ 3,000$ for the first year. During the three succeeding years annual appropriations of $\$ 6,000, \$ 8,000$, and $\$ 12,000$, respectively, were made to carry on the work. Douglass Houghton was State geologist during the life of the first Survey. The results of the work are contained in five annual reports, the last bearing the date of 1842, all of which were published in the State senate and house documents. At the end of the fourth year no further provision for the Survey was made and the work ceased.

Geologic work in Michigan was resumed in 1859, when the second Geological Survey was organized, under the direction of Prof. Alexander Winchell, but this was quickly interrupted by the outbreak of the civil war. The only publication was a first biennial report of progress, which was issued in 1861.

\section{PRESENT SURVEY.}

LEGAL DESIGNATION AND DATE OF ORGANIZATION.

The present organization is entitled the Michigan Geological and Biological Survey; it was organized under the law of 1869 , which was slightly modified in 1905 .

\section{HISTORICAL SIETCH.}

By act of the State legislature of 1869, which continues in force to the present time, the board of geological survey, consisting of the governor, the superintendent of public instruction, and the president of the board of education, was constituted. This board was authorized to "supervise the continuance and completion of the 
geological survey of the State, and for that purpose they may, from time to time, appoint such person or persons to assist in making said survey as may be deemed necessary."

The first executive officer under this act was Alexander Winchell, who on April 24, 1869, was appointed "director of the Geological Survey of Michigan." The following year the director was authorized to employ Prof. Raphael Pumpelly "to take charge and conduct a survey of the copper regions."

In 1871 Prof. Winchell resigned and Carl Rominger was appointed to make a survey of the Lower Peninsula and of the eastern part of the Upper Peninsula during the years 1871 and 1872, and Maj. T. B. Brooks was engaged to continue a survey of the iron regions during the same period.

In 1872 a contract was awarded for the publication of 200 copies of volume 1 of the State Survey reports. This was the first of the series generally known as the "large green volumes," the publication of which was discontinued with volume 9 , issued in 1902 .

During the year $1873 \mathrm{Dr}$. Rominger, with two field parties, investigated the coal beds of the State. During the following year Rominger's investigations were confined more especially to timber, soil, water supply, elevations, etc., with a view to making popular reports on these subjects.

In 1885 Charles E. Wright was appointed State geologist for one year, beginning March 1 . Subsequently he was reappointed and held the position until the spring of 1888 , when he was succeeded by M. E. Wadsworth, who held the office until July 1, 1893. Mr. Wadsworth was followed by Dr. L. L. Hubbard, who served as State geologist until his resignation in 1899 , when Dr. Alfred C. Lane, who had been assistant State geologist during Hubbard's entire term of office, was appointed to fill the position. Dr. Lane continued as State geologist until September 1, 1909, when he resigned, and R. C. Allen, the present incumbent, was appointed to the office.

\section{SUMMARY OF LAWS.}

The purpose for which the Survey was established, as stated in the act creating it, is as follows:

It shall be the duty of said board to make, or cause to be made, a thorough geological and mineralogical surrey of the State, embracing a determination of the succession and arrangement, thickness, and position of all strata and rocks, their mineral character and contents, and their economical uses; an investigation of soils and subsoils, and the determination of their character and agricultural adaptation; the investigation of all deposits of brines, coal, marl, clay, gypsum, lime, petroleum, and metals and metallic ores, building stone, marble, gritstone, materials for mortar and cement, mineral paint, and. all other productions of the geological world within the limits of the State, capable of being converted to the uses of man. 
It shall be the duty of said board to furnish an annual report of the progress of the survey, and as often as possible a condensed statement of important and interesting facts for general circulation.

To carry into effect the provisions of the act above quoted the sum of $\$ 8,000$ was appropriated annually until the completion of the survey, no part of the appropriation to be used for the printing of reports.

In 1905 the legislature extended the functions of the board of geological survey by directing it to make, under the general direction of the State geologist appointed by the board, " a thorough biological survey of the State, embracing a determination of the range and distribution of the various plants and animals inhabiting the State and the relation to their environment and the welfare of man." This act carried an annual appropriation of $\$ 1,000$ for two years, for the purpose of making the biologic survey, and this appropriation was renewed by the sessions of 1907 and 1909 . The act provides that no part of the appropriation shall be used for the printing of reports.

ORGANIZATION.

By the act of 1869 the governing board is called board of geological survey and is composed of the governor, the superintendent of public instruction, and the president of the board of education, who serve ex officio. At present the personnel of the board is as follows: President, Hon. Chase S. Osborn, governor of the State; vice president, Hon. D. M. Ferry, president of State Board of Education; secretary, Hon. L. L. Wright, superintendent of public instruction. The members of the board do not receive compensation for their services.

The board is empowered to engage such persons as it may deem wise, without civil-service intervention, and to fix the compensation of employees. The term of office of the director (State geologist) is indefinite. He receives an annual salary.

The present staff of the Survey consists of the director, an assistant geologist, a chief field naturalist (in charge of biologic survey), and a secretary. R. C. Allen is the director. College professors and advanced students are given temporary positions in the field during the field season, and occasionally the students are employed in drafting and other office work.

\section{APPROPRIATIONS.}

Under the law of 1869 the sum of $\$ 8,000$ is appropriated annually until the completion of the work of the Survey. In addition, the legislatures of 1905,1907 , and 1909 appropriated $\$ 1,000$ annually for the biologic work of the Survey, and during the last decade various amounts, averaging about $\$ 2,000$ annually, have been appropriated 
for cooperation with the United States Geological Survey in the preparation of topographic maps.

Unexpended balances lapse to the State treasury at the end of the fiscal year (June 30), but bills contracted before that date will be paid from unexpended balances up to December 15.

About 50 per cent of the general appropriation $(\$ 8,000)$ is expended for administrative work. The remainder is used for geologic field work, traveling expenses, office incidentals, etc.

The appropriation for cooperative topographic work is expended mainly in field work.

Of the $\$ 1,000$ apropriated annually for the biologic survey, the chief field naturalist receives an annual salary of $\$ 400$; the remainder is expended in field work, including salaries of assistants.

PUBLICATIONS.

Since the organization of the present Survey in 1869 a large number of publications have been issued. These include two brief progress reports (published in 1869 and 1871) ; a series of detailed reports on the general and economic geology of the State, comprising volumes 1 to 9 , inclusive, published between 1873 and 1902 ; a series of annual reports, comprising 12 volumes; two annual reports devoted to the work of the biologic sirvey; and publications 1,2 , and 3 of a new series. These publications include reports, of both a general and a detailed nature, on the areal, stratigraphic, economic, and paleontologic geology of different sections of the State, or of the State as a whole.

The board of geological survey has full control over the distribution of reports. Publications are sent to educational institutions in the State without charge, and to individuals, for purposes of instruction, on receipt of transportation charges. To nonresidents a regular charge is made. All moneys received from the sale of reports are paid into the State treasury.

The printing of all reports is executed by the State printer, who holds a two-year contract for all State work. The cost of printing is paid from a general fund and does not come out of the Survey appropriation.

\section{PRESENT LINES OF WORK.}

Independent investigations.-At present the Survey is primarily engaged in an investigation of the salt industry of the State, and in geologic surveys of the Huronian areas in the Northern Penirsula and of the copper district. The biologic work of the present season will consist of a botanical survey of the peach belt of western Michigan.

Cooperation with the United States Geological Survey.-The topographic survey of the State is conducted in cooperation with the Federal Survey, with a joint appropriation of $\$ 4,000$. 


\section{MINNESOTA.}

\section{HISTORICAL SUMMARY.}

The Minnesota State legislature of 1872 passed an act creating the Geological and Natural History Survey, and for 33 years the work of this organization was prosecuted with varying vigor and support. This law, which was drawn by President William Watts Folwell, of the University of Minnesota, was very comprehensive in its scope. It provided for explorations in geology, geography, archeology, zoology, botany, and topography, the preparation of a map of the State, and the establishment of a geologic and natural history museum. In fact, it provided for one of the most comprehensive surveys that was ever organized in this or any other country, but since the establishment of this Survey many other surveys of equally wide scope have been established. The law creating this survey read as follows:

SEction 1. It shall be the duty of the board of regents of the University of Minnesota to cause to be begun as soon as may be practicable, and to carry on, a thorough geological and natural history survey of the State.

Sec. 2. The geological survey shall be carried on with a view to a complete account of the mineral kingdom, as represented in the State, including the number, order, dip, and magnitude of the several geological strata; their richness in ores, coals, peats, clays, salines and mineral waters, marls, cements, building stones, and other useful materials; the value of said substances for economical purposes, and their accessibility; also an accurate chemical analysis of the various rocks, soils, ores, clays, peats, marls, and other mineral substances, of which complete and exact record shall be made.

Sec. 3. The natural-history survey shall include, first, an examination of the vegetable productions of the State, embracing all trees, shrubs, herbs, and grasses, native or naturalized in the State; second, a complete and scientific account of the animal kingdom, as properly represented in the State, including all mammals, fishes, reptiles, birds, and insects.

SEc. 4. The said surveys and examinations shall be made in the manner and order following: First, the geological survey proper, together with the necessary and implied mineralogical investigations, all of which shall be undertaken as soon as may be practicable and be carried forward with such expedition as may be consistent with economy and thoroughness; second, the botanical examinations; third, the zoological investigations: Provided, however, That whenerer the said board of regents may find it most economical to prosecute different portions of the surreys in conjunction, or that the public interest demands it, they may, in their discretion, depart from the above-preseribed order. And in the employment of assistants in the said surveys, the board of regents shall at all times give the preference to the students and graduates of the University of Minnesota, provided the same be well qualified for the duties:

SEc. 5. The said board of regents shall also cause to be collected and tabulated such meteorological statistics as may be needed to account for the varieties of climate in the various parts of the State; also to cause to be ascertained [by] barometrical obserrations or other appropriate means the relative elevations and depressions of the different parts of the State; and also, on or before the completion of the said surveys, to cause to be compiled from such actual surveys and measurements as may be necessary, an accurate map of the State, 
which map, when approved by the governor, shall be the official map of the State.

SEc. 6. It shall be the duty of said board of regents to cause proper specimens, skillfully prepared, secured, and labeled, of all rocks, soils, ores, coals, fossils, cements, building stones, plants, woods, skins, and skeletons of animals, birds, insects, and fishes, and other mineral, vegetable, and animal substances and organisms discovered or examined in the course of said surveys to be preserved for public inspection free of cost in the University of Miunesota, in rooms convenient of access and properly warmed, lighted, ventilated, and furnished aud in charge of a proper scientific curator; and they shall also, whenever the same may be practicable, cause duplicates in reasonable numbers and quantities of the above-named specimens to be collected and preserved for the purpose of exchanges with other State universities and scientific institutions, of which latter the Smithsonian Institution at Washington shall have the preference.

SEc. 7. The said board of regents shall cause a geological map of the State to be made as soon as may be practicable, upon which, by colors and other appropriate means and devices, the various geological formations shall be represented.

SEc. 8. It shall be the duty of the said board of regents, through their president, to make, on or before the second Tuesday in December in each and every year, a report showing the progress of the said surveys, accompanied by such maps, drawings, and specificatious as may be necessary and proper to exemplify the same to the governor, who shall lay the same before the legislature; and the said board of regents, upon the completion of any separate portion of the said surveys, shall cause to be prepared a memoir or final report, which shall embody in a convenient manner all useful and important information accumulated in the course of the investigation of the particular department or portion; which report or memoir shall likewise be communicated through the governor to the legislature.

SEc. 9. To carry out the provisions of this act the sum of $\$ 1,000$ per annum is hereby appropriated, to be drawn and expended by the [said] board of regents of the University of Minnesota.

SEc. 10. This act shall take effect and be in force from and after its approval.

After the passage of this act and its approval by Governor Austin in 1872, Newton H. Winchell was appointed State geologist. For 28 years, or until the year 1900, the survey was prosecuted vigorously under his direction, and it proved to be one of the most successful investigations ever undertaken in the State. The publications comprised 24 volumes of annual reports, giving from year to year a statement of the work carried on in the prosecution of the survey; 10 bulletins, published at different times, giving special results of explorations; and a final report, consisting of five volumes of text and one volume of maps, giving a summary of the information gained for the benefit of the Commonwealth.

In 1873 the legislature enacted a supplementary law, under which certain State lands, known as State salt lands, were assigned to the board of regents, the money derived from the sale of the lands to be disbursed by the board of regents in accordance with the law author-

S5645 - Bull. $465-11-6$ 
izing the Geological and Natural History Survey of the State. This law also increased the annual appropriation for the maintenance of the Survey from $\$ 1,000$ to $\$ 2,000$ annually.

In 1900 the geologic work under the Geological and Natural History Survey was formally discontinued, but the botanical and zoologic work was continued for a number of years, under varying appropriations. Occasional geologic explorations were also authorized. These were placed under the direction of Prof. C. W. Hall, who up to the present time has continued to look after the collections of the Survey and to attend to the geologic correspondence.

In 1905 , by the codification of the laws of the State, the act creating the Geological and Natural History Survey was abolished, thereby blotting out the legislation under which scientific explorations had been conducted for 33 years. The funds which had accumulated from the sale of salt spring lands were, however, left in the hands of the board of regents, to be used by them in scientific explorations. Although the amount of these funds is not large, it has been most helpful in aiding scientific work along the original lines of the survey, particularly zoologic and botanic research.

During the many years of prosecution of field work by the Survey a vast amount of geologic material was gathered for the laboratory investigations incident to the preparation of reports. Under the law this material was to belong to the scientific museum, which the board of regents was authorized to build up." Owing to a lack of funds and the growth of the university it has not been possible to put this material in the shape of a useful, practical museum, but it is stored for use as soon as the resources of the regents shall permit them to give the space required for its display.

\section{MISSISSIPPI.}

\section{PREVIOUS SURVEYS.}

An act of the legislature of Mississippi entitled "An act to further endow the University of Mississippi," approved March 5, 1850, was the first authorization of a geologic survey of the State. Under this law the trustees of the university elected Dr. John Millington, at that time professor of natural sciences at that institution, as the first State geologist and B. L. C. Wailes as assistant State geologist.

This first survey was not only a geologic and agricultural survey, but contemplated a complete biologic survey of the State as well. Dr. Millington was too old to do active field work, and the prosecution of the survey fell principally upon Prof. Wailes. Much work of a reconnoissance character was done by Prof. Wailes in an effort to unfold the geologic structure of the State, large collections of specimens were made, and a Ștate mușeụm waș eștabliṣhẹ. The 
fossils collected were chiefly from the Jackson and Vicksburg formations and were determined by T. A. Conrad. When the report was ready for publication in 1854 it embodied so largely the results of Prof. Wailes's work that Dr. Millington thought that to publish it under his own name would be an injustice to his coworker. His recommendation that it be published in Wailes's name was adopted, and the publication is known as "Wailes's report on agriculture and geology of Mississippi."

In 1854 Lewis Harper succeeded Wailes as State geologist and Eugene W. Hilgard was appointed assistant State geologist. During the next three years the work of the Survey was carried on by these men, chief attention being given to the economic aspects of the investigations. The results are embodied in a report on the agriculture and geology of Mississippi published in 1857.

In 1857 Hilgard succeeded Harper as State geologist. He was preeminently well qualified for the work. Educated in Germany; he had thorough and special training in chemistry and agricultural science, besides being an accomplished geologist. He studied the geologic structure of the State and the economic products and soils thoroughly and accurately. He made large and valuable collections of specimens, which are now in the cabinets of the State University.

As a result of his studies, Hilgard in 1860 published a most creditable report on the geology and agriculture of Mississippi. The civil war broke out before the reports were received from the St. Louis publisher, and not until after the close of the war were they put into circulation.

During the civil war appropriations for the Survey stopped, except the $\$ 1,200$ salary of the State geologist, which, though small, was continued in appreciation of the valuable services which Dr. Hilgard had given the State.

After the close of the war, owing to the general financial depression, no further appropriations for the geologic survey were made, though Hilgard continued to serve as State geologist until 1869, being assisted by Eugene A. Smith and R. H. Loughridge. In 1869 Hilgard resigned his work in Mississippi and went to Michigan. $\mathrm{He}$ was succeeded as State geologist by Dr. George Little, of Alabama, who was assisted by E. A. Smith. Though valuable field notes were collected by Drs. Little and Smith, no reports were published by them. The Survey lacked financial support and died a natural death.

\section{PRESENT SURVEY.}

LEGAL DESIGNATION AND DATE OF ORGANIZATION.

The present organization is entitled the Geologic, Economic, and Topographic Survey of Mississippi; it was created by act of legislature of March, 1906. A. F. Crider was director from 1906 to 1909. 


\section{SUMMARY OF LAWS.}

The objects of the Survey as embodied in the act are as follows: To examine the economic natural resources of the State; to prepare a topographic map of the State; to examine and classify the soils of the State; to investigate the water resources of the State; to examine and report on road-making materials of the State; to examine the physical features of the State in their relations to the occupations of the people; to prepare such other special geologic reports as may be necessary; and to consider any other kindred scientific and economic questions.

In May and November of each year the geological commission meets and receives the report of the Director of the Survey. The commission in turn is required to report to the legislature at each regular and special session the progress of the work of the Survey.

The geological commission has general supervision of the work of the Survey in administrative matters; but the technical details of the work, the assignment of work to assistants, and the supervision of that work are left to the director of the Survey.

Persons engaged in the work of the Survey are privileged to enter upon and investigate any lands within the State and are protected by law in the performance of their official duties.

ORGANIZATION.

The governing board is the geological commission, consisting of five members-the governor of the State, the State superintendent of education, the director of archives and history, the chancellor of the State University, and the president of the State Agricultural and Mechanical College. These officers are ex officio members of the commission and serve during the tenure of their respective offices. With the exception of the secretary of the commission, who receives $\$ 25$ a month, the members receive no compensation for their services.

The executive officer is designated director of the State Geclogical Survey. The present incumbent is E. N. Lowe, who was appointed by the commission June 4, 1909. The director can not hold any other office and is required to give his whole time to the work of the Survey. His term of office is not limited. He is paid an annual salary, which is fixed by the commission.

The following subordinates are employed: One clerk and four geologic and other assistants. One university professor and two advanced students have been employed by the Survey during the present year.

\section{APPROPRIATIONS.}

Appropriations are biennial and are not contingent upon cooperation. Unexpended balances revert to the State treasury immediately on the expiration of the year. The annual appropriation is $\$ 8,000$, 
of which $\$ 2,000$ is for salary of director and $\$ 6,000$ for salaries of assistants and expenses. The expenditures are made in about the following proportions:

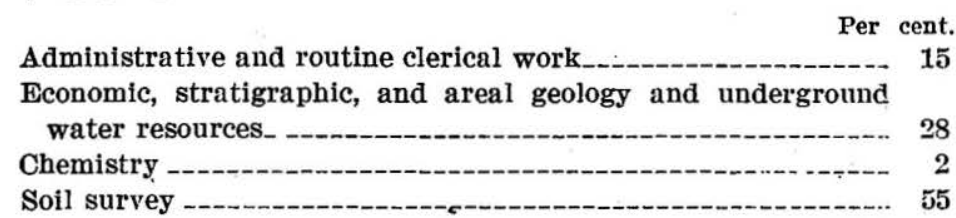

Clerical assistance in the office is limited to the summer season, when the director is much of the time in the field. The soil survey is continued throughout the year, but all other field work is largely cut down during the winter.

\section{PUBLICATIONS.}

All publications of the Survey are in the form of bulletins. Eight of these have thus far been published, in editions of 2,000 copies each.

For the first three years the cost of printing averaged $\$ 1,665$ a year and was paid out of the State printing fund. In March, 1910, a geologic printing fund of $\$ 1,000$ a year was provided.

The Survey has absolute freedom as regards printing, except choice of printer. The State printer does the printing for the Survey under a general contract with the State.

The Survey has entire control of the distribution of reports. They are sent free, aside from postage, to intelligent citizens all over the State, to the related departments of the State government, to the higher educational institutions in the State, to the United States Geological Survey and related departments at Washington, to all State surveys which desire to exchange, to all geologists expressing a desire for them, to the higher educational institutions of the country, to public libraries, and to foreign geological surveys desiring to exchange.

\section{PRESENT LINES OF WORK.}

Independent investigations.-The Survey is at present engaged primarily in an investigation of structural materials in the State and in a study of the soils with special reference to erosion and the methods of preventing it.

Cooperation with United States Geological Survey.-Cooperation is maintained with the Federal Survey in the study of the Coastal Plain deposits of Mississippi and the water resources of the State.

Cooperation with United States Bureau of Soils.-In cooperation with the Bureau of Soils of the United States Department of Agriculture, a classification of the soils of the State is in progress, the 
basis of cooperation being that each bureau shall furnish the same number of men, and each field party shall consist of one man from the Federal Bureau and one man from the State Survey.

\section{MISSOURI.}

\section{PREVIOUS SURVEYS.}

FIRST GEOLOGICAL SURVEY.

The act creating the first Geological Survey of Missouri was approved by the governor February 24, 1853. Under this act the governor was authorized to appoint a State geologist, who, with assistants, was to make a thorough geologic and mineralogical survey of the State. Prof. G. C. Swallow, of Maine, was appointed to the position, and organized the department the same year. Under his direction the Survey continued active operations until 1861, when it was discontinued because of the civil war.

The publications of the first Survey consisted of the "First and second annual reports," published in 1855 as one volume divided into two parts, part 1 containing 207 pages and part 2 containing 240 pages; the third, fourth, and fifth progress reports, consisting of small brochures; and a special report of 93 pages, published in 1859. entitled "Geological report of the country along the line of the Southwest Pacific Railroad, State of Missouri."

\section{SECOND GEOLOGICAL SURVEY.}

The second Geological Survey was created in May, 1870, by the passage and approval of an act which established a "Mining, Metallurgical, and Geological Bureau," with headquarters at St. Louis. By this act the governor was authorized to appoint a governing board, consisting of one member from each congressional district. This board appointed Albert D. Hager to the position of State geologist. Mr. Hager resigned in August, 1871, when Dr. J. G. Norwood was placed in temporary charge. On November 25, of that year, Raphael Pumpelly was appointed State geologist. He served until May, 1872, when, on his resignation, Prof. G. C. Broadhead was appointed to the office. Prof. Broadhead resigned in 1874, when the instruments and records of the Survey were moved to Rolla, Mo., and placed in charge of Prof. Charles Williams, who was made acting director. The second Survey was abolished in 1876.

The publications of the second Survey consisted of a volume of county reports (324 pages) covering work done between 1855 and 1871; Hager's annual report (23 pages), published in 1871; Pumpelly's report ( 655 pages and atlas), published in 1872; Broadhead's report (734 pages), published in 1874; and Williams's report (177 pages), published in 1876 . 


\section{PRESENT SURVEY.}

LEGAĹ DESIGNATION AND DATE OF ORGANIZATION.

The present organization is entitled the Bureau of Geology and Mines; it was organized under an act approved May 13, 1889.

\section{HISTORICAL SKETCH.}

By the provisions of the act of May 13, 1889, the organization and direction of the work of the Bureau are under the supervision of the board of managers, consisting of the governor, who is ex officio president of the board, and four members appointed by the governor from the State at large. On August 29, 1889, Arthur Winslow was appointed director and State geologist, and he served until 1894. On his resignation Prof. C. R. Keyes was appointed to the position, and he served until 1897. On his resignation Dr. John Gallaher, of Warrensburg, was appointed, and he served until his death, which occurred July 21, 1900, when his son, Leo Gallaher, was made acting State geologist. In September, 1901, Dr. E. R. Buckley was appointed director and State geologist. He resigned in May, 1908, at which time he was succeeded by H. A. Buehler, the present incumbent.

\section{SUMMARY OF LAWS AND ORGANIZATION.}

As stated above, the work of the Bureau is under the supervision of the board of managers, the members of which are appointed for a term of four years and receive no compensation other than traveling expenses.

The executive officer under whose supervision the work of the Survey is performed is called director and State geologist. $\mathrm{He}$ is appointed by the board and serves until his successor is chosen. The appointment and removal of assistants are optional with the director and are without civil-service restrictions. The salary of the director is fixed by law at " not to exceed $\$ 3,000$," and the salary of the assistant State geologist at "not to exceed $\$ 1,800 . "$ The salaries of the remaining employees are regulated by the board of managers.

The director and from three to five assistants devote their entire time to the work of the Bureau. Usually several temporary assistants are employed during the field season. At present only a small proportion of the work is performed by college professors or advanced students. A chemist and a draftsman are employed continuously, and a stenographic clerk has charge of the office work. Additional office assistants are employed from time to time as required. 


\section{APPROPRIATIONS.}

The Bureau receives a biennial appropriation, which is not conditional upon cooperation. If the entire appropriation is not expended during the biennial period the sum remaining reverts at once to the State treasury. The appropriation during the present biennium is $\$ 12,500$ annually for geology and $\$ 5,000$ annually for topography.

The appropriation is expended approximately as follows:

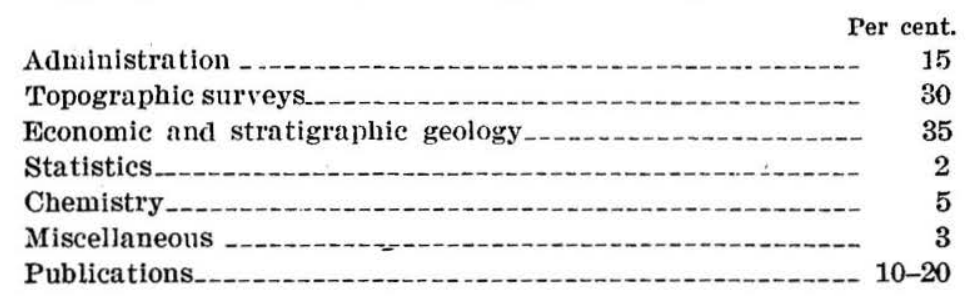

PUBLICATIONS.

The publications of the present Geological Survey of Missouri comprise a first series of geologic reports numbering 13 volumes, a second series of geologic reports numbering 9 volumes, and a series of biennial progress reports submitted by the director to the board of managers and by the board transmitted to the legislature. The geologic reports are chiefly of an economic nature, but include several county reports, two volumes on the paleontology of Missouri, two volumes on the areal geology, and one volume on the surface features of the State. The edition of the geologic reports is usually 3,000 copies. The cost of printing is paid out of the Survey appropriation.

All manuscripts are submitted to a publication committee, consisting of two members of the board of managers. After receiving their approval the reports are published under the direct supervision of the State geologist. The printing is done by the State printer.

\section{PRESENT LINES OF WORK.}

During the present biennial period the Bureau has the following investigations under way:

Independent investigations.-A study of the iron ores of the State, geologic mapping in Jackson County, a study of the Aurora lead and zinc area, reconnoissance work along the southern boundary of the State, and geologic mapping in Phelps County.

Cooperation with the United States Geological Survey.-The Bureau is cooperating with the Federal Survey in a study of the "Coal Measures," in statistical work covering mineral production, in the collection of deep-well records, and in topographic mapping. 
NEBRASKA.

\section{HISTORICAL SKETCH.}

The first attempt to establish a Geological Survey in Nebraska was made in 1891, when the present State geologist, Edwin H. Barbour, who had recently become a resident of the State, was appointed State geologist by Gov. Thayer. The appointment was purely an honorary one, there being no funds available for the payment of either salary or expenses. The newly appointed State geologist therefore defrayed his own expenses the first year. In 1892 the Hon. Charles H. Morrill proffered an annual allowance of $\$ 1,000$ for the maintenance of geologic work in the State.

In 1893 the State legislature enacted that the head professor of geology in the University of Nebraska should be the State geologist, without stipend.

In 1899 the board of regents of the University of Nebraska, in recognition of the importance of a Geological Survey, provided that $\$ 500$ should be devoted to the work during 1899 and $\$ 250$ annually during 1900, 1901, and 1902.

In 1901 the legislature made the first appropriation for the Survey: the sum of $\$ 1,200$ being allotted for the biennium of 1901 and 1902 . Since that time the legislature has, at the request of the State geolugist, made the following additional appropriations to carry on the work of the Survey: $1903-4, \$ 2,000 ; 1905-6, \$ 2,000 ; 1907-8, \$ 2,500$; 1909-10, \$2,500. For the biennium of 1911 and 1912 the sum of $\$ 10,000$ has been requested. Unexpended balances lapse to the State treasury on August 1 following the close of a biennium, which is March 31.

The Nebraska Geological Survey has no governing board. The executive officer is the State geologist, who has direct supervision over the Survey, employing such help as he can within the scope of the appropriations.

As Nebraska is a distinctly agricultural State, with no mines and few mineral resources, it has enacted no mining and geologic laws.

\section{PUBLICATIONS.}

The publications of the Survey consist of four volumes and comprise one report on the general geology of the State, one county report, five economic reports, eleven paleontologic papers, and two papers on prehistoric man in Nebraska. Several manuscripts are awaiting publication. The editions of the reports are limited to 1,000 copies.

Bids for printing are advertised for by the State printing board and the contract is let to the lowest bidder, but the director of the Survey specifies kind of paper, type, binding, etc. 
Two hundred copies of each report are filed with the State librarian for exchange and distribution; the others are distributed by the Survey to institutions gratuitously and to individuals on the payment of postage.

\section{PRESENT LINES OF WORK.}

Independent investigations.-During the past season men and teams were employed and the first attempt at detailed geologic work was made. The stratigraphy of five counties was worked out with considerable minuteness. This work is to be vigorously continued during the season of 1911. A separate report will be devoted to each county.

Cooperation with United States Geological Survey.-The topographic work which the United States Geological Survey has done in this State has covered only about a third of the area, and it is the purpose of the State geologist during the next biennium to benefit as far as means will allow by cooperation with the Federal Survey.

\section{NEW JERSEY.}

\section{PREVIOUS SURVEYS.}

ROGERS SURVEY, 1835-1840.

The first geologic survey of New Jersey, commonly known as the Rogers survey, was authorized by act of the legislature dated February 26, 1835. Henry D. Rogers, professor of geology in the University of Pennsylvania, was appointed to make the survey. Reports of progress were presented in 1836, 1837, and 1838, and a final report was published in 1840 , the latter an octavo volume of 301 pages, with a geologic map of the State on a scale of 6 miles to the inch and two cross sections. The more important geologic periods were recognized and their formations mapped and described, emphasis being given to the economic products. The total amount appropriated was $\$ 5,000$, and the work of the survey terminated with the submission of the final report.

KITCHelL SURVEY, 1854-1856.

In January, 1854, Gov. R. M. Price recommended that a thorough geologic survey of the State be authorized. This was done in March of the same year, and Dr. William Kitchell was appointed superintendent and State geologist, Dr. George H. Cook assistant geologist, Dr. Henry Wurtz chemist and mineralogist, and Gen. E. L. Viele topographic engineer. The law provided for a thorough geologic survey by townships, with county reports. Work was carried on in 1854,1855 , and 1856, and annual reports for those years, also a report 
on the geology of Cape May County, were published. Good progress had been made, particularly in determining the distribution and character of the iron ores, green-sand marl, and clay deposits, and more or less topographic work had been completed in 8 of the 21 counties of the State, when the work was suspended. A total of $\$ 49,000$ was appropriated during these three years, but owing to the poor condition of the State's finances only a portion of this was ever available and the survey died of financial starvation, leaving much work in an unfinished condition.

In 1860 the State Agricultural Society secured the passage of an act by which Dr. Kitchell was allowed free use of all material and data collected by his survey, for the purpose of publishing a final report and map at his own financial risk. 'Owing to Dr. Kitchell's death in 1861 nothing resulted from this legislation.

In 1863 the same society secured the passage of a law authorizing its officers to receive all the survey material and data, which were to be transferred to Dr. George H. Cook or some other suitable person, with a view of completing the survey as contemplated in the agreement with Dr. Kitchell. Under this authorization some work was done in 1863, with results so satisfactory that in $1864 \mathrm{Dr}$. Cook persuaded the legislature to establish a new Survey, which has since been continuously maintained.

\section{PRESENT SURVEY.}

LEGAL DESIGNATION AND DATE OF ORGANIZATION.

The title of the present organization is Geological Survey of New Jersey; it was established by act of the legislature in March, 1864 .

IIISTORICAL SKETCH.

In the law establishing the Geological Survey of New Jersey Dr. George H. Cook was named as State geologist. Dr. Cook continued in that office until his death in 1889 . In 1890 Dr. John C. Smock, who since 1864 had been almost continually associated with Dr. Cook in the work of the Survey, was made State geologist. He resigned in 1901, and was succeeded by Dr. Henry B. Kümmel, who had been connected with the Survey since 1892. At first it was contemplated that the work of the Survey would be completed in four years, and it was so specified in the act of 1864 . This clause, however, was soon repealed, and by successive acts, passed at five-year intervals, financial support was provided for the Survey until 1895 . Since that time an appropriation for the Survey has each year been made in the regular appropriation bill. 
SUMMARY OF LAWS.

The original act has been so extended and modified from time to time by amendment and supplement that the legal provisions under which the Survey is conducted can be better understood from a summary than from the quotation of statutes. The law recognizes ": the duty of the State to develop and render available to the fullest extent the facts relative to its great natural resources, as also of its agricultural, mining, mechanical, and other industrial interests," and it places upon the Survey the carrying out of this duty.

There is a board of managers, composed originally of two from each congressional district, but now of one from each congressional district (of which there are 10) and not more than 10 from the State at large. The board was formerly self-perpetuating, but its members are now appointed by the governor, who is ex officio president of the board, and are confirmed by the senate, for terms of five years each, not more than four being appointed each year. The board has power (1) to appoint the State geologist and to fix his salary, (2) to fix the salaries of his permanent assistants, (3) to approve for publication all reports submitted and direct the distribution, by sale or otherwise, of reports, maps, and suites of specimens, and (4) "on the application of at least five owners of separate lots of land included in any tract of land in this State which is subject to overflow from freshets, or which is usually in a low, marshy, boggy, or wet condition," to examine such tracts, and, if deemed for the public interest, to survey and make a plan for their drainage, which plan is to be submitted to the supreme court, with a request for the appointment of commissioners to carry out and execute the works of drainage and to assess, collect, and pay the expenses incurred. In practice the board of managers is chiefly an advisory body, the general direction and the details of management of the Survey being left to the State geologist.

The State geologist has by law authority (1) to appoint assistants (subject to the provisions of a later-enacted civil-service law); (2) to fix salaries of temporary assistants, to purchase necessary instruments, supplies, and materials, and to direct all incidental expenditures; (3) to enter, with his assistants, without molestation, upon all lands in the State to further the objects of the Survey; and (4) to prepare or cause to be prepared both administrative reports and scientific reports and maps on subjects pertinent to the work of the Survey. By custom he has authority in all matters relating to the Survey not specifically reserved by law to the board of managers. From time to time the legislature has directed the State geologist to make special surveys of various kinds, such as of forestry conditions in the State and routes for inland waterways. 
ORGANIZATION.

The governing body is the board of managers, made up as stated under "Summary of laws." Apart from their power to appoint the State geologist, fix salaries, and, through a committee, audit all expenditures, their duties are chiefly advisory. Regular meetings are held twice a year; special meetings when required. Members of the board receive no compensation but are reimbursed for expenses incurred in attending meetings.

The State geologist is appointed by the board of managers, subject to the approval of the governor, and holds office at the pleasure of the board. He is by law ex officio executive officer of the forest commission of New Jersey and gives considerable attention to the direction of that work but receives no extra compensation therefor. $\mathrm{He}$ is not at liberty to undertake outside professional work or to hold other positions. The present State geologist, Henry B. Kümmel, was appointed January 1, 1902, and is the third to hold that office since the establishment of the Survey in 1864. His compensation is an annual salary, fixed by the board of managers and paid in monthly installments.

The headquarters of the Survey are in the capitol building at Trenton, N. J.

There are two clerical assistants, who are appointed by the State geologist from eligible lists furnished by the State civil service commission. They are employed continuously and are subject to removal by the State geologist at any time and for any cause except politics or religion. Their compensation ranges from $\$ 40$ to $\$ 75$ a month.

One geologic assistant and one chemist are continuously employed, and temporary geologic assistants are engaged from time to time on a per diem basis. The temporary assistants are chiefly instructors and professors in geology in colleges and universities. The monthly compensation of these assistants ranges from $\$ 75$ to $\$ 150$, and the per diem rates from $\$ 3$ to $\$ 10$.

Under a cooperative agreement with the Bureau of Soils of the United States Department of Agriculture and the New Jersey State Agricultural Experiment Station, the Survey for two months pays the salary and the field expenses of two field assistants in an agricultural survey. The salary of these field assistants, who are students of the State Agricultural School, is $\$ 25$ a month.

Under a cooperative agreement with the State road oommissioner, two assistants in the chemical laboratory, engaged partly in survey work and partly in work for the State road commissioner, are carried on the commissioner's pay roll at the rate of $\$ 50$ and $\$ 60$ a month. 
Under civil-service rulings some scientific positions are in the competitive class and others are exempted.

The topographic and engineering work of the Survey is in charge of a consulting engineer of high standing, who has an office in New York City. His employees are detailed to the work as the exigencies of the case demand and are not subject to civil-service regulations. All men in this group are paid on a per diem basis, for time actually employed, at rates ranging from $\$ 4$ to $\$ 10$ a day.

\section{APPROPRIATIONS.}

Appropriations for the Survey are made annually in the general appropriation bill. They are not contingent on cooperation with any other organization. Unexpended balances in the hands of the State treasurer at the close of the fiscal year (October 31) immediately lapse to the State treasury, although there may be outstanding bills awaiting payment. Under certain restrictions, however, uncompleted contracts may be filed against a balance, and so carry it over into the next fiscal year.

The present annual appropriation is $\$ 16,500$. With the exception of the salary of the State geologist, the payment of which is specified in the bill, the expenditure of the appropriation is left to the State geologist. Special funds have sometimes been provided for specific investigations ordered by the legislature.

The expenditures for 1909 may be classed as follows:

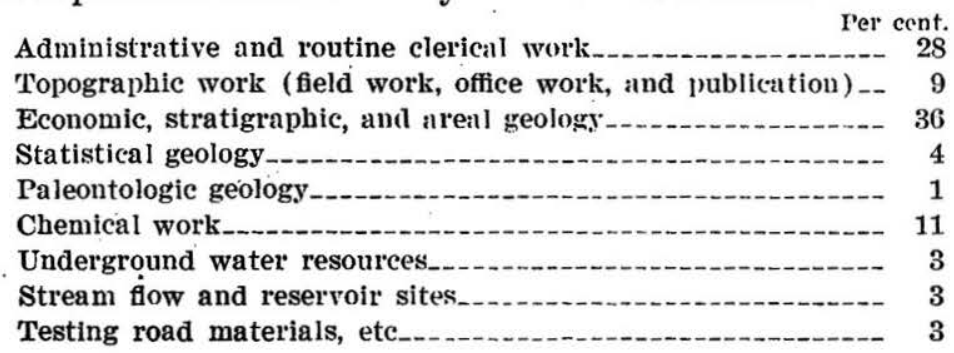

PUBLICATIONS.

From 1864 to 1909 , inclusive, the Survey has issued an annual report for each year except 1868 . These include administrative reports and scientific papers. In 1868 , at the completion of the first four-year period of the Survey, a final report, entitled "Geology of New Jersey," by G. H. Cook, was published. This series of annual reports, with accompanying scientific papers, is to be replaced by a series of bulletins, numbered consecutively and each dealing with a distinct subject. The annual administrative report of the State geologist, dealing with the business of the Survey, will hereafter be issued as one of this series of bulletins, 
In 1888 a series of monographs, or so-called final reports, was commenced. These are published at irregular intervals. Volumes 1, 2 (pts. 1 and 2), 3, 4, 5, 6, and 7 of this series have already appeared.

In 1886 a series of reports on paleontology was commenced. Volumes 1 and 2 were published in cooperation with the United States Geological Survey, and appeared also as monographs. Volume 3 was issued in 1903 and volume 4 in 1907.

Two series of topographic maps are published and kept in stock. One series is on a scale of 1 mile to the inch and covers the entire State. This series was surveyed originally from 1880 to 1887, in cooperation with the United States Geological Survey, but by a topographic corps organized by the State Survey. The entire cost of this work, exclusive of the primary triangulation by the United States Coast and Geodetic Survey, but including tertiary triangulation over about 2,000 square miles, was $\$ 54,744.58$, or $\$ 6.93$ per square mile. Work done by earlier organizations reduced the cost about 50 cents per square mile, and if the Survey had been compelled to furnish its own triangulation the cost would have been about $\$ 10$ per square mile. About half of the expense of this work was met by the United States Geological Survey. These maps have been revised from time to time and the culture brought down to date. Twenty sheets make up this set. The second series of topographic maps is on a scale of 2,000 feet to the inch and covers the metropolitan district. The topography is taken from the earlier maps, revised where necessary, and additional data relating to culture added. Twentyfour sheets of this series have been published and are kept in stock.

Geologic folios, data for which are furnished in part by the members of the State Survey, are published in cooperation with the United States Geological Survey, a special edition of 1,000 copies being prepared as the "Geologic Atlas of New Jersey."

Of the annual reports, 4,500 copies are published and about 3,700 distributed immediately. Editions of the final reports vary from 2,000 to 5,000 and of the paleontologic reports from 1,000 to 1,500. Maps are printed in editions of 1,000. The reports are distributed without charge, excepting the last 200 copies of each edition, which are sold at cost. For the larger reports recipients are required to pay postage or express charges. Maps are sold at 25 cents a sheet, and geologic folios at the same price as fixed by the United States Geological Survey. The average annual income from the sale of publications is from $\$ 1,100$ to $\$ 1,200$, which is paid monthly to the State treasurer and can not be redrawn for the use of the Survey.

The average annual cost of printing the Survey reports and accompanying maps from 1902 to 1909 , inclusive, the period of the present 
administration, has been $\$ 3,200$, or $\$ 2,131$ for each report. The cost of the annual reports has ranged from $\$ 554$ to $\$ 2,204$, and for volumes of the final report and paleontologic seriés from $\$ 912$ to $\$ 7,000$. The average cost of reports from 1891 to 1900 was $\$ 5,484$. The cost of printing reports and maps which accompany them is paid from the appropriation for public printing. The cost of engraving and printing the topographic atlas sheets and the cost of the geologic folios is paid from the appropriation for the support of the Survey.

All matters relating to the printing of maps paid for from Survey funds are solely in the hands of the State geologist. Contracts for printing reports are awarded by the State printing board (composed of the governor, State comptroller, and State treasurer) after competitive bidding. The quality of paper and size of type are fixed by. them, according to certain legal requirements. The subject matter of the reports, the style, the number of illustrations, etc., have for two or three years been subject to the censorship of the editor of public documents. This censorship is by no means formal, and some departmental reports are vigorously pruned. Reports of the Survey, however, have heretofore been passed without change. Special reports (not annual reports) must be ordered printed by the State printing board.

About 100 copies of each report are retained by the superintendent of public documents for use of the legislature. The remainder of the edition is delivered to the Survey for distribution. Reports are sent to working geologists, to other geological surveys in this country and abroad, to public libraries in New Jersey, to many colleges, universities, and libraries in other States, and to citizens of New Jersey and other States who request them. The mailing list is kept alive chiefly by the elimination of those who for two or three years in succession neglect to return the acknowledgment card inclosed in each report, and by the addition of those requesting that reports be sent to them regularly.

\section{PRESENT LINES OF - WORK.}

INDEPENDENT INVESTIGATIONS.

The present main lines of work of the Survey, independent of other departments or bureaus, are as follows:

1. Revision and publication of new editions of topographic maps as rapidly as old editions are exhausted. On an average two or three new atlas sheets are published annually. On some sheets the changes in the culture have been so extensive as to necessitate the engraving of new copper plates to replace the lithograph stones.

2. The compilation and publication of a new State geologic map in two sheets on a scale of $1: 250,000$. 
3. The publication of a report on iron ores and iron mining and the preparation of a report upon the surface formations of the Coastal Plain, the field work of which has already been completed.

4. Paleobotanic investigations of the flora of the Coastal Plain deposits.

5. The testing of coal purchased by State institutions to determine its heat-producing values.

COOPERATIVE INVESTIGATIONS.

United States Geological Survey.-Cooperation with the Federal Survey is being carried on along several lines:

1. Geologic folios, to which workers of both surveys have contributed, are engraved and printed by the United States Geological Survey. At the time of printing a certain number are struck off for the State Survey. These are bound in a special cover and sold to the State Survey at cost of presswork and paper. Four of these joint folios have already been published and others are in preparation.

2. In 1909 the State Survey cooperated with the United States Geological Survey in the collection of statistics of mineral production in the State. This plan of cooperation was not carried out during 1910, owing to the taking of the national census, but it is expected that it will be resumed in 1911.

3. The State geologist has been appointed a special agent of the United States Geological Survey for the collection of well data and as such finds the work of obtaining well records and samples greatly facilitated. The records are filed with the State Survey and are open to inspection at any time by members of the National Survey.

Other State surveys.-No cooperative work is carried on at the present time with geological surveys of other States.

United States Bureau of Soils.-In 1909 the Bureau of Soils of. the United States Department of Agriculture, the State Agricultural Experiment Station of New Jersey, and the Geological Survey of New Jersey entered into a cooperative agreement relating to an agricultural and soil survey of the State. Most of the work in connection with the chemical analyses of the soils is done by the State Survey, which also contributes to the expenses of the field parties in both the soil survey and the agricultural canvass, the other two bureaus bearing the remainder of the field expenses and making the necessary physical determinations.

State road commissioner.-The State Survey is cooperating with the State road commissioner in the construction of improved State roads, of which New Jersey now has 1,527 miles. The Survey from time to time furnishes the commissioner with information regarding

$85645^{\circ}$-Bull. 465-11-7 
the occurrence of materials suitable for roads and passes on the suitability of materials submitted by road contractors. A more important line of work during the last two years has been in connection with the use of asphaltum binder and heavy residual oils in the construction of macadam roads. A large part of the time of the chemist of the Survey has been devoted to investigations to determine the best type of oil to be used and to framing specifications. During the road-building season, before the oil is used, samples from each carload supplied are required to be tested in the laboratory of the Survey, to determine whether or not the oil conforms to the specifications. The expense of this work is defrayed in part by the State road commissioner.

\section{NEW YORK.}

\section{PREVIOUS SURVEYS.}

The Geological Survey of New York is the outgrowth of the scientific activity of Amos Eaton, first senior professor of the Rensselaer School, at Troy, supported by the substantial patronage of Gen. Stephen Van Rensselaer and the encouragement of Gov. Dewitt Clinton. At the request of the latter, Eaton delivered lectures on geology and allied sciences before the legislature of the State, and under the patronage of Van Rensselaer he executed geologic surveys of Rensselaer County and the district adjoining the Erie Canal. After several recommendations by Gov. Clinton, and in response to later petitions from organized societies in Albany and New York, the secretary of state, John A. Dix, was in 1835 authorized to present to the legislature a plan for a general natural-history survey of the State, in which scheme a geologic survey was to hold a leading place. This report, rendered in 1836 , formed the fundamental plan on which the Geological Survey of New York was based. In accordance therewith the State was divided into four districts, with a district geologist and one assistant in charge of each, and it was believed that four years would be sufficient for the accomplishment of the work. Annual reports were to be rendered by each chief geologist, and final reports were to be submitted at the close of the work.

The district geologists appointed under the provisions of this act were Lieut. W. W. Mather, Prof. Ebenezer Emmons, Lardner Vanuxem, and Timothy A. Conrad. In 1837 a partial rearrangement of these appointments was made, by which James Hall, assistant during the first year to Prof. Emmons, took the place of Mr. Conrad, the latter being appointed paleontologist to the Survey. Concomitant with this change was a redivision of the western or third and fourth districts by a north-south line instead of an east-west line. It was not till 1842 and 1843 that the final reports were sub- 
mitted, and with their submission the organization terminated its active existence as such, though the title of the Survey has never been abrogated. The publications of this early Survey comprised 16 annual reports and four final reports.

The work of the organization was continued by the designation of Prof. Emmons to take charge of the reports on agriculture (in which this distinguished geologist found opportunity to expound in full his Taconic system of rocks), and by the appointment of James Hall to continue the work on the paleontology of the New York formations. The title of State geologist and paleontologist was thus kept alive by the activities of Prof. Hall, and in 1892 both were reaffirmed by a new commission issued to Prof. Hall by Gov. Flower. The 13 quarto volumes devoted to the paleontology of New York, which were published between the years 1842 and 1894, constitute a monument to the labors of James Hall and his assistants and form one of the standards of North American paleontology.

In 1898, on the death of Prof. Hall, the regents of the University of New York, who had statutory control of the offices, appointed F. J. H. Merrill as State geologist and John M. Clarke as State paleontologist.

- In 1904, on the consolidation of the University of the State of New York and the Department of Public Instruction into the Education Department, John M. Clarke was appointed State geologist and paleontologist, and he still holds these titles, in connection with the directorship of the Science Division of the Education Department and the State Museum.

\section{PRESENT SURVEY.}

LEGAL DESIGNATION AND DATE OF ORGANIZATION.

The present organization is known as the Science Division (Geological Survey) of the Education Department; it was organized in 1904.

\section{SUMMARY OF LAWS.}

Under the codified education law (1910), the commissioner of education and the regents of the University of New York appoint the State geologist and paleontologist. No other statute bears on this office. The work of the official and of the division is a matter of agreement between the appointee and the commissioner.

\section{ORGANIZATION.}

The governing authority is vested in the commissioner of education and the regents of the University of the State of New York. The commissioner is appointed for life by vote of the regents. The 
regents are elected to office, for specific periods, on joint ballot of the State senate and assembly.

The executive officer is the State geologist and paleontologist, who is appointed by the commissioner of education and the regents of the University of New York. His term of office is during effieiency and good behavior. The State geologist is also director of the Science Division of the Education Department. The present incumbent is John M. Clarke. The State geologist and paleontologist receives an annual salary, fixed annually by law, on recommendation of the commissioner of education.

The permanent force of the Survey consists of six clerical assistants and seven geologic assistants. In addition, from five to twelve temporary geologic assistants are employed as required by the work of the Survey. The temporary assistants are college professors and, occasionally, advanced students. All appointments are made on recommendation of the State geologist, with the approval of the commissioner of education. All permanent positions are subject to competitive civil-service examination. Temporary appointments are subject to exemption by the State civil-service commission.

\section{APPROPRIATIONS.}

Appropriations are annual. None are contingent on cooperation. Unexpended balances are carried over, except in case of salaries, which lapse at the close of the fiscal year.

-The salaries of the permanent staff amount to $\$ 21,260$. Expenses, including cost of temporary assistants, are estimated at $\$ 7,000$. The appropriation for maintenance covers the entire Science Division.

\section{PUBLICATIONS.}

The publications of the Survey consist of a series of bulletins and a series of memoirs. Annual reports are issued as bulletins. All are included in the annual reports of the State Museum and are also published separately. The editions vary from 3,000 to 5,000 .

The publications are distributed gratuitously to registered libraries and scientific correspondents; the remainder are sold. The income from the sale of publications is deposited daily with the State treasurer.

The average annual cost of printing is $\$ 25,000$. This is paid from the State printing fund. The printing is done by the State printer, under general contract with the State. The sizes of the reports are standard-quarto for memoirs and octavo for bulletins. The paper: illustrations, and contents are left to the State geologist and paleontologist, subject to approval of the commissioner of education. 
Aside from the stipulation that copies of all publications shall be sent to registered libraries, the- distribution is left to the State geologist.

\section{PRESENT LINES OF WORK.}

The present lines of work of the Survey comprise economic and tectonic geology, stratigraphy, areal mapping, surficial geology and mapping, mineralogy, and paleontology.

No cooperation is maintained.

\section{NORTH CAROLINA.}

\section{PREVIOUS SURVEYS.}

In 1823 an act of the general assembly of the State of North Carolina authorized the board of agriculture to pay the expenses of "geological excursions" for a period of years. The work was begun by Prof. Denison Olmsted, of the State University, and during his incumbency nine reports were published.

Upon Prof. Olmsted's removal to Yale in 1825 the Survey was continued by Dr. Elisha Mitchell, also of the State University, under whose direction nine reports were published.

In 1852 Dr. Ebenezer Emmons was appointed State geologist, and during his service 23 reports on the geology and natural history of the State were published.

On the death of Dr. Emmons, in 1866, Dr. W. C. Kerr was appointed State geologist, and carried on the work until his death in 1885. During Dr. Kerr's administration 21 reports and scientific papers were published.

After the death of Prof. Kerr the Geological Survey was allowed to lapse until 1891, when the North Carolina Geological Survey was established, and Prof. Joseph A. Holmes, of the State University, was appointed State geologist. The object of this Survey, as expressed in the act of the general assembly authorizing it, was "the thorough examination of the nature and extent of the mineral and timber resources of the State." The Survey continued its work for 14 years and during this time issued 12 bulletins, 8 economic papers, biennial reports Nos. 1 to 7, covering the period 1891 to 1904, and a series of good roads circulars numbered from 1 to 37 .

The act creating the North Carolina Geological Survey was repealed by the legislature in 1905 and a new act was passed establishing the present Survey. 
PRESENT SURVEY.

LEGAL DESIGNATION AND DATE OF ORGANIZATION.

The present organization is known as the North Carolina Geological and Economic Survey; it was established by the General Assembly of North Carolina in February, 1905.

During 1905 and until October, 1906, Joseph Hyde Pratt, State mineralogist, was acting State geologist, in the absence of Prof. Holmes, who was in St. Louis as chief of the department of mines and metallurgy of the Louisiana Purchase Exposition. On October 29, 1906, Dr. Pratt was formally appointed State geologist.

\section{SUMMARY OF LAWS.}

The act establishing the North Carolina Geological and Economic Survey provides that the State geologist shall be appointed by the governor to conduct the work of the Survey under the supervision of a board of managers, known as the geological board. The board is to consist of the governor, as chairman, and four citizens of the State, who are appointed by the governor, with the approval of the senate; two for a period of two years and two for a period of four years, beginning March 1, 1905. The objects of the Survey, as defined in this act, are as follows:

1. An examination of the mineral, forest, fishery, and other material resources of the State.

2. An examination of the geological formations of the State with reference to their economic products.

3. An examination of the road-building materials and the best methods of utilizing the same.

4. An examination and classification of the soils and forests and other physical features of the State with special reference to their bearing upon the occupation of the people.

5. An examination of the streams and water powers of the State with special reference to the development for manufacturing enterprises and the preservation of the sources of these streams through the protection of the forests.

6. The consideration of such other scientific and economic problems as in the judgment of the geological board shall be deemed of value to the people of the State.

7. The preparation of such reports, illustrations, and maps as may be deemed necessary in placing the results of these investigations before the public.

8. And the State geologist, with the approval of the geological board, is hereby authorized to arrange for and accept such aid and cooperation from the several United States Government bureaus and other sources as may assist in completing the topographic surveys of the State and in carrying out other provisions of this act.

9. An examination of the water supplies of the State with special reference to the sinking of deep or artesian wells, 
Governing board.-The governing body is the geological board: appointed as stated above. The members of the board are reimbursed the amount of their actual traveling expenses, and "members not otherwise receiving a salary from the State may, in addition, be paid a per diem of $\$ 4$ for not exceeding eight days during any one year." Executive officer.-The executive officer is the State geologist. The present incumbent is Dr. Joseph Hyde Pratt, who was appointed by the governor October 29, 1906, for a term ending January 1, 1909, or until his successor is appointed. Dr. Pratt is also professor of economic geology in the University of North Carolina, but spends practically all of his time on Survey work. He receives an annual salary, the amount of which is fixed by the geological board, and which is paid in monthly installments.

Subordinates are chosen by the State geologist, with the approval of the geological board.

Clerical force.-The office assistants include a secretary, a stenographer, and two clerical assistants, one of whom also serves as janitor.

Geologic division.-There is mo regular geologic assistant at present, but geologists are employed temporarily for specific work. Cooperation with the United States Geological Survey exists, and the geologists employed by the State Survey have included Federal geologists as well as professors from the University of North Carolina and from other colleges and a few advanced college students.

Topographic division.--Under cooperative agreements the North Carolina Geological and Economic Survey has employed United States Geological Survey men for all topographic work done in North Carolina. The salaries of these men are fixed by the Federal Survey. The State Survey's allotment for this work has been from $\$ 1,000$ to $\$ 2,500$ a year. A part of this fund is furnished by the counties in which special mapping is being done.

Highway division.-The Survey regularly employs a highway engineer at a fixed salary, and from time to time other engineers are employed for limited periods. W. L. Spoon is in charge of this work. During the summer months of 1910 from 10 to 12 college students were employed on surveying parties in the location and construction of roads. Much of this work is done under cooperation with counties and individuals.

Forestry division.-The work of the forestry division of the Survey is under the direction of the forester, J. S. Holmes. He is assisted, however, by men from the United States Forest Service, who are placed in the State on a cooperative basis.

Drainage division.-Through the efforts of the North Carolina Geological and Economic Survey a bill has been passed looking to 
the drainage of swamp and overflowed lands in the State. These lands have been divided into districts, and all persons owning lands in these districts bear their part of the expense of the drainage work in proportion to the benefits derived. The Survey has charge of the drainage of certain of the State lands belonging to the State board of education, to the extent of approving the accounts of the drainage engineers engaged in the work.

Natural history division.-Through the efforts of the Survey the legislature of 1907 passed a bill establishing the North Carolina Fish Commission. This commission is under the direction of the Geological Survey, its accounts being subject to approval by the State geologist. The influence of the commission is limited, however, owing to the fact that under the law certain areas are not under its jurisdiction, and efforts are being made to procure remedial legislation. The object of the commission is the preservation and scientific study of the principal fishes of economic value and the encouragement of the cultivation of the oyster and the diamond-back terrapin.

The North Carolina Geological and Economic Survey, in cooperation with the State Audubon Society, has in preparation a report giving a list and description of the birds found in North Carolina.

It is the purpose of the Survey to issue as complete a report as possible on the flora of the State.

\section{APPROPRIATIONS.}

Appropriations are annual and are not contingent on cooperation. Balances are carried from one fiscal year to another. The amount of the appropriation is $\$ 15,000$ annually, $\$ 5,000$ of which is to be devoted to road work and the remainder expended for such purposes as shall be approved by the geological board. The expenditures for the fiscal year 1908-9 were in about the following proportions:

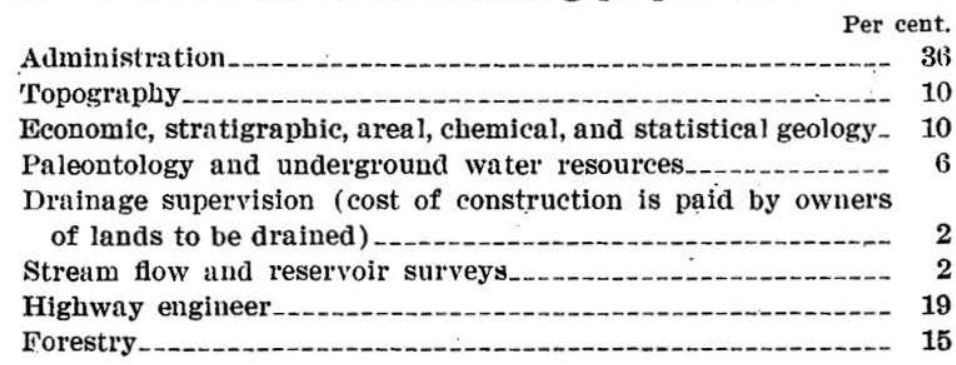

\section{PUBLICATIONS.}

The publications of the North Carolina Geological and Economic Survey consist of a series of bulletins, of which 10 have been issued; a series of economic papers, of which 11 have been issued; three 
special volumes; two biennial reports; a series of press bulletins, numbered from 1 to 39 ; and a series of good-roads circulars, numbered from 38 to 57. These treat of a wide range of subjects, including geology, forestry, biology, water powers, mining, etc., but are chiefly of an economic nature.

The edition of all except the press bulletins and the good-roads circulars is 3,000 copies.

The publications are distributed free of cost, except postage.

The cost of printing reports and maps is paid out of the State treasury. The cost of preparing maps is paid out of the Survey fund, the expense of preparing the county maps being shared by the counties.

The reports are printed by the State printers. The Survey has choice as to style of reports, kind of paper, illustrations, etc.

The Survey has entire control over the distribution of the reports. The exchange list consists of all reciprocating geological surveys, all Government departments desiring the reports and furnishing franks for mailing, and institutions and persons who furnish their publications as exchanges. This list is kept alive by correspondence, by use of the monthly list of the Library of Congress, and by a mail-card list, the persons and institutions on which are notified of each new publication and of the amount of postage it requires.

PRESENT LINES OF WORK.

\section{INDEPENDENT INVESTIGATIONS.}

Most of the work now being prosecuted by the North Carolina Geological and Economic Survey is broadened and made more effective by cooperation with some Federal department, county, or individual. The principal independent report at present in preparation is a volume on the mineral resources of North Carolina.

COOPERATIVE INVESTIGATIONS.

United States Geological Survey--Several investigations are in progress in cooperation with the Federal Survey. Reports on the geology and water resources of the coastal plain of North Carolina have been prepared and are going through the press. Under this agreement the North Carolina Survey paid the salary and expenses of three of the investigators, also a stipulated sum to Dr. William Bullock Clark, of Johns Hopkins University, who has had general supervision of the work.

A cooperative investigation of the mica deposits of the State is also in progress.

Statistics of the production of minerals in North Carolina are collected in cooperation with the United States Geological Survey. 
In topographic and traverse mapping the North Carolina Geological and Economic Survey has undertaken to complete maps of certain counties in the State. The county pays half of the cost of the field work, the State Survey the other half, and the United States Geological Survey prepares the map for the engraver.

Other departments of the National Government.-In the highway work the State Survey has the cooperation of the United States Office of Public Roads, which furnishes lecturers on the subject and frequently an engineer to construct sample roads in different townships and counties. No special appropriation for this work is made from either bureau. The State Survey has also cooperated with the North Carolina Good Roads Association and the Southern Appalachian Good Roads Association in issuing good roads literature and press bulletins, which have had a decided educational value.

The forestry division of the State Survey has had the active cooperation of the United States Forest Service. The State Survey pays the salary and expenses of a State forester, and the United States Forest Service pays the salary and expenses of a Federal forester.

The Fish Commission of North Carolina. is under the supervision of the State Geological Survey, and this commission has been assisted by the United States Coast and Geodetic Survey and the United States Bureau of Fisheries in the work of laying off the restricted territory for fishing.

Other scientific bureaus of the State.-In the drainage work the State Geological Survey has cooperated to a certain extent with the State Board of Education in the drainage of certain State lands.

\section{NORTH DAKOTA.}

\section{PRESENT SURVEY.}

The present organization is the first Geological Survey of North Dakota.

LEGAL DESIGNATION AND DATE OF ORGANIZATION.

The present organization is known as the North Dakota Geological Survey. It was established by act of the legislature in 1895 .

\section{SUMMARY OF LAWS.}

The following is a summary of the laws governing the Survey:

The board of trustees of the State University is authorized to carry on a geologic survey of the State. The objects of the Survey are to investigate the geologic formations, together with their ores, coals, clays, mineral waters, marls, cements, building stones, and other useful materials; to collect and tabulate such meteorologic statistics 
as may be needed to determine the climate of various parts of the State; to ascertain, by barometrical observations or otherwise, the elevations of different parts of the State; and to prepare a geologic map of North Dakota, upon which the geologic formations shall be represented by means of colors and patterns.

The Survey is authorized to collect specimens of all rocks, soils, ores, coals, fossils, cements, building stones, etc., and to preserve them for public inspection in the University of North Dakota. So far as practicable, duplicate specimens shall be collected for purposes of exchange with other universities and scientific institutions, of which the Smithsonian Institution shall have the preference.

On the completion of any piece of work the Survey is to prepare a report embodying all useful and important information accumulated in the course of the investigation.

The professor of geology in the State University is designated ex officio State geologist.

\section{ORGANIZATION.}

The governing board of the North Dakota Geological Survey is the board of trustees of the State University, which is composed of five members, appointed by the governor for a term of four years. The members serve without compensation, but are reimbursed for traveling expenses incurred while attending the meetings of the board.

The present State geologist is Prof. Arthur Gray Leonard, who was appointed to the professorship of geology in the State University in July, 1903. The appointment is without fixed time limit. Approximately half the time of the State geologist is given to the work of the Survey. He receives an annual salary as professor in the university, and in addition is paid a per diem rate while engaged in field work for the Survey. The salary is fixed by the governing board. The assistant professor of geology in the State University is assistant geologist on the Survey, being appointed by the board for an indefinite term. During the field season several advanced students are employed by the State geologist in the work of the Survey, their salaries ranging from $\$ 40$ to $\$ 60$ a month.

\section{APPROPRIATIONS.}

The appropriation for the Survey is a continuing one and is not contingent on cooperation. Unexpended balances are carried over to the next fiscal year. The annual appropriation is $\$ 1,000$. Approximately 90 per cent of this is devoted to economic, stratigraphic, and areal geology and about 10 per cent to administrative and clerical work. 
PUBLICATIONS.

The publications of the Survey consist of biennial reports, five of which have been issued. The size of the edition is 3,000 . The reports are distributed free, except postage.

The average cost of the reports is about $\$ 1,000$ a year. The cost of the printing does not come from the Survey appropriation but from other. State funds. The Survey has no choice as to the printer, the statutes providing that the State printer shall do the work. The selection of the paper rests largely with the printer, but otherwise the Survey has full control over the printing, including the contents of the reports, where and by whom the maps and illustrations shall be made, and the style of the reports.

The Survey has full control over the distribution of its reports. The mailing list includes the public and school libraries of North Dakota, the State officers and members of the legislature, many of the State newspapers, and persons who have asked to be placed on the list. It also includes many public libraries throughout the United States, the libraries of many colleges and universities, scientific and other learned societies at home and abroad, libraries of other geological surveys, and a large number of geologists and others interested in the reports. As the reports are issued notices of their publication are sent out, and all who respond by sending the necessary postage receive copies.

\section{PRESENT LINES OF WORK.}

Inclependent investigations.-The main lines of work which are being carried on by the Survey at the present time are as follows: (1) A study of the late Cretaceous and early Tertiary formations of western North Dakota, including the mapping of these formations; (2) the continued investigation of the lignite deposits of the State; (3) the study of the Devils Lake area, with particular reference to its physiographic features; and (4) the detailed study of the geology and economic resources of other selected areas.

Cooperation with United States Geological Survey.-In cooperation with the United States Geological Survey data regarding the underground waters of North Dakota are being collected as rapidly as possible.

\section{OHIO.}

\section{PREVIOUS SURVEYS.}

FIRST GEOLOGICAL SURVEY.

On December 8, 1835, Gov. Robert Lucas, in his annual message to the general assembly of Ohio, recommended the establishment of a Geological Survey. This was the first official indorsement of 
such an enterprise in Ohio. The assembly responded with a joint resolution appointing a committee of four, headed by. Dr. S. P. Hildreth, one of the best-informed men in Ohio on the geology and natural resources of the State, who were to report to the next assembly the best method of securing the desired end.

The committee submitted a carefully prepared report, and in March, 1837, an act was passed providing for "a complete and detailed geological survey of the State." The work planned was comprehensive, including not only matters strìctly geologic, but also analyses of soils, ores, marls, and waters. The preparation of a geologic map of the -State was specifically mentioned, as was a collection of the rocks, ores, and fossils. It was proposed to send sets of these to the principal educational institutions of the State, thus bringing the Survey closely into touch with the scholars of Ohio.

The committee thought that the work of such a Survey might be completed in four years, with an annual appropriation of $\$ 12,000$. This part of the report appears humorous, in view of the area of the State, the large amount of work done by the second and subsequent surveys, and the fact that "a complete and detailed survey" is still in the distant future. Doubtless, however, present ideas of a "detailed survey" are quite different from those of 1837.

The law empowered the governor to employ a "competent and skilled geologist." Even in those days appointments were apparently sometimes made on a basis other than merit, and the legislature concluded to take no chances in regard to the new scientific bureau. The law made provision for geologic assistants, not to exceed four in number, and for a topographical engineer, who should, among other things, "ascertain by accurate barometrical observations the height of the principal mountains of the State."

The governor appointed W. W. Mather, of New York, principal geologist, and S. P. Hildreth, John Locke, J. P. Kirtland, and C. Briggs, jr., assistants. Charles Whittlesley was chosen topographic engineer. The selections were of the best, and the Survey started with the good will and rather high expectations of the people.

Field work began in 1837, and in December the first annual report was filed with the governor. This was published in 1838 , under the title "First Annual Report of the Geological Survey of the State of Ohio," by W. W. Mather, principal geologist, and the several assistants. This modest volume of 134 pages discussed various subjects, such as coals, iron ores, and salt.

Field work was continued during the summer of 1838 , and a report on this work was filed with the governor the following December. It contained a description of the general geology of the State and a discussion of special topics, such as dip, topography, and coal. The publication of this second annual report marked the close of the 
first Survey. The causes for its abrupt termination are not well known, but perhaps the financial crisis was the leading factor. According to Dr. Orton the principal facts established by this Survey were as follows: (1) The oldest rocks of the State are the so-called blue limestone formation of southwestern Ohio; (2) the newest bedded rocks are the "Coal Measures" of southeastern Ohio; and (3) a very gentle southeasterly or southerly dip prevails throughout Ohio, a proper understanding of which renders its stratigraphy intelligible.

\section{SECOND GEOLOGICAL SURVEY.}

Efforts to renew the Survey were made in succeeding years, but without success until 1869. At that time Gov. Hayes took the lead and the Geological Survey of Ohio was reestablished without difficulty. The work was to be completed in three years. The governor appointed J. S. Newberry chief geologist; E. B. Andrews, Edward Orton, and J. H. Klippart assistant geologists; and T. G. Wormley chemist. Klippart was interested in agriculture and was expected to give his attention to that important field. Local and special assistants were from time to time appointed, some of whom were or have since become leaders in their respective fields. The list includes G. K. Gilbert, R. D. Irving, J. J. Stevenson, N. H. Winchell, F. B. Meek, E. D. Cope, James Hall, O. C. Marsh, R. P. Whitfield, and D. S. Jordan.

Newberry outlined a comprehensive plan for the Survey, including a thorough discussion of the stratigraphy and paleontology of the entire State. The economic side was to be considered in one volume, and agriculture, botany, and zoology were to be treated in another volume. At the close of the three years a large part of this work remained to be done.

Reports of progress for 1869,1870 , and 1871 were published. That for 1869 contained a geologic map of Ohio, being the first official publication of the kina to be issued by the State. A series of detailed reports followed. Of these, volume 1 was published in 1873 , volume 2 in 1874, and volume 3 in 1878. These reports are devoted principally to a review of the geology of the State, by counties, but part 2 of volume 1 and part 2 of volume 2 relate to paleontology and contain numerous fine lithographic plates of which students of paleontology are justly proud. The expense of these plates, however, was large, those of volume 1 alone costing $\$ 34,000$. Volume 4 was published in 1882. Instead of treating of agriculture, botany, and zoology, as was expected, it is devoted entirely to vertebrate zoology.

These volumes were issued in editions of 20,000 , and the expense to the State was heavy. In 1879 a geologic map of the State on a 
scale of 4 miles to the inch was issued. This is the basis of the maps of 1888 and 1909.

Early in the history of the Survey criticism arose. The people expected that the publications would treat prominently of the economic resources of the State, and had little interest in the elaborate plates given to fossil plants and animals. In April, 1872, the law was changed and provision was made for a geological board, consisting of the governor, school commissioner, and treasurer, who should have general supervision of the survey. Unfortunately the chief geologist lived in New York and was absent from Ohio during a large part of the year, especially in winter; when the general assembly was in session. A financial crisis increased the difficulty. Appropriations were made with growing opposition and were finally discontinued.

The live interest in the economic resources of the State, however, is shown by an appropriation passed April 17, 1882, to cover the cost of preparing the long-delayed economic volume. But this act also stipulated that "upon the publication of said volume 5 the Geological Survey of Ohio is hereby declared to be completed." The work was to be in charge of a geologist appointed by the governor, who at once (April 17) appointed Edward Orton. In 1884 volume 5 appeared. It is devoted almost wholly to coal, and is the most sought publication of the Survey.

Notwithstanding its action in 1882, limiting the life of the Survey, the general assembly on May 1, 1885, made provision " to extend and complete the account of the economic geology of the State that was begun in volume 5." In $1886 \mathrm{Dr}$. Orton published a preliminary report (76 pages) on petroleum and natural gas, and in 1888 the detailed report (vol. 6) on those products appeared. This volume has proved almost as popular as volume 5. It seems safe to state that these two volumes have done as much to render the Survey popular with the people of Ohio as all other publications of the organization combined.

Though large editions of the early reports (vols. 1 to 6 ) were issued, they were distributed almost wholly pro rata among members of the general assembly. As a result the members found themselves in possession of hundreds of volumes for which there was no demand, and many of these were destroyed. No thought was taken of the future, and in a few years persons desiring volumes were compelled to search the shelves of secondhand-book stores.

\section{THIRD GEOLOGICAL SURVEY.}

In 1889 , on the recommendation of Dr. Orton, the legislature provided for the third organization of the Geological Survey of Ohio. A small yearly appropriation was made, enabling the State geologist, 
Dr. Orton, to keep in touch with work in progress and to present the results in annual reports. The scope of the Survey was made very broad, and, while permission was given to collect and describe the fossils of the geologic formations, the law forbade any expenditure for this purpose that was not expressly provided for by the legislature. Probably this was attributable to the heavy expenditures made for part 2 of volumes 1 and 2 . The first annual report of this Survey appeared in 1890 . In the fall of 1891 Dr. Orton's health failed, incapacitating him from active field work, but publications on the results accomplished by the Survey were continued under his direction, part 1 of volume 7 appearing in 1893 and the complete volume (parts 1 and 2) in 1894.

\section{PRESENT SURVEY.}

LEGAL DESIGNATION AND DATE OF ORGANIZATION.

The present organization is known as the Geological Survey of Ohio; it was organized under the laws of 1889 and 1902.

HISTORICAL SIKETCH.

In the autumn of 1899 Edward Orton, jr., was appointed to the vacancy created by the death of his father, and in 1902 he completed the fourth organization of the Geological Survey of Ohio. The laws of the third organization were not repealed, but important additions were made, relating to the publication and distribution of the reports. Provision was made for issuing a series of bulletins, which were later to be assembled and bound into volumes, thus maintaining the series started by Newberry and continued by Orton. This was regarded as a more expeditious and economical method of making public the results accomplished. Without difficulty Prof. Orton secured an appropriation, and in the summer of 1900 field work was once more begun. Prof. Orton gave the work of the Survey a more practical trend than it had previously had, as is well shown by the titles of the bulletins-for example, "Uses of Portland cement," "Manufacture of Portland cement,". and " Sand-lime brick." Finding that he could not devote to the Survey the time that he deemed necessary, Prof. Orton retired in 1906, and J. A. Bownocker, the present incumbent, was appointed to succeed him.

Since Mr. Bownocker's appointment only one addition has been made to the laws relating to the Survey, and that empowers the State geologist to purchase and keep on sale publications of the Survey now out of print. In 1910 a general code of the laws of Ohio was adopted, and the laws governing the Survey were all assembled. 
1. The governor may appoint a State geologist, who shall serve for a term of three years, unless removed for cause. He may employ such assistants as he deems necessary.

2. The State geologist shall receive for his services $\$ 200$ for each month for the time employed in the discharge of his official duties. Each assistant shall receive such compensation as the State geologist may allow. The necessary traveling and incidental expenses of the geologist and assistants shall be paid each month from the State treasury on presentation of an itemized voucher approved by the governor.

3. The State geologist shall investigate the geologic structure and resources of the State. He shall determine as nearly as possible the number and extent of geologic formations, and from time to time represent them on maps and diagrams. He shall study the occurrence and distribution of useful minerals and products of such formations, determine their chemical composition and structure, investigate the soils and water supply of the State, and give attention to the discoveries of coal, building stone, natural cement, petroleum, gas, and other natural substances of use and value. He may also collect and describe the fossils of geologic formations of the State, but no expenditure shall be incurred therein unless authorized by the general assembly.

4. When a bulletin has been completed, the commissioners of public printing shall determine the number of copies to be printed and the grade of paper and kind of binding to be used and shall provide for a proper publication. Each issue of a bulletin shall consist of not less than 3,000 copies. One thousand copies shall be distributed pro rata among members of the general assembly, and each member may draw 50 additional copies. One thousand copies shall be distributed by the State geologist in exchange with other surveys and among persons whose services have been employed in the collection and preparation of matter used therein. Not more than 400 copies of a bulletin may be distributed in this manner during the first year after its publication, and not more than 50 copies in any subsequent year. One thousand copies shall be reserved for binding. When a sufficient number of other bulletins have accumulated to make collectively a volume of not less than 800 pages, they shall be bound in such a way as to correspond with the preceding volumes of the Survey.

5. The State geologist shall distribute the bound volumes of the Survey as follows: (1) To the State library, 100 copies; (2) to each member of the general assembly, 1 copy and, on application, $85645^{\circ}-$ Bull, $465-11-8$ 
not to exceed 2 additional copies; (3) to each public library of the State, 1 copy; (4) the remaining copies may be distributed in exchange with other geological surveys and societies of the United States and foreign countries.

6. The expenses of printing, illustration, stereotyping, and binding of the bulletins and volumes shall be paid from the appropriation for State printing.

7. The State geologist may purchase, repair, and sell, at 'such prices as to cover the expenses, publications of the Survey now out of print.

8. The State geologist shall make an annual report to the governor on the work for the preceding year. The report shall state the number of bulletins and geologic reports distributed, the number of each issue sold, the money received and expended, and the number of bulletins and bound volumes on hand.

ORGANIZATION.

The executive officer of the Survey is the State geologist. The present incumbent, J. A. Bownocker, was appointed in December: 1906, to fill the unexpired term of Edward Orton, jr., resigned. $\mathrm{He}$ was reappointed April 22, 1907, and again in 1910. His present term expires in 1913. The State geologist holds a professorship in the Ohio State University and gives only about one-third of his time to the Survey during the academic year, and full time during the summer vacation of three months. During the vacation period he receives a salary of $\$ 200$ a month and traveling expenses, as provided by statute; during the remaining nine months his compensation is $\$ 50$ a month, the amount appropriated by the general assembly.

The clerical force consists of one stenographic clerk.

The scientific assistants are appointed by the State geologist and include geologists, chemists, and engineers. At present the scientific staff is chosen almost entirely from professors in higher institutions of learning and advanced students who have selected geology for their life work. The field work is performed largely during the summer vacation. During 1910 ten geologists, two chemists, and two engineers were employed. The compensation of assistants ranges from $\$ 50$ to $\$ 100$ a month and expenses. It is expected that the maximum figure will be substantially increased for 1911 .

The topographic work is not under the direction of the State geologist.

APPROPRIATIONS.

During the last few years appropriations have been made annually: but it is understood that hereafter they will be biennial. Unexpended balances lapse on February 15 following the time the appropriations 
become available. Thus far such balances have been reappropriated to the Survey. The appropriation for the year 1910 was as follows: For geologic work, $\$ 6,895$; for illustrating specimens, $\$ 150$; total, $\$ 7,045$. To this should be added unexpended balances and the receipts from the sale of bulletins, the latter aggregating from $\$ 200$ to $\$ 400$. The expenditures were divided approximately as follows:

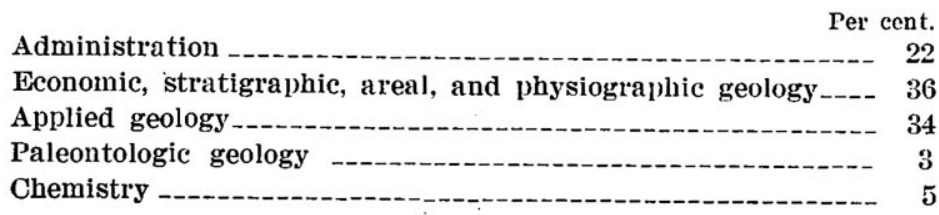

PUBLICATIONS.

The publications of the present Survey date from 1903 and consist of a series of bulletins, which are from time to time assembled and bound into volumes, thus maintaining the series of volumes started by Newberry. To the present time 11 bulletins have been issued. Bulletins 1 to 3 compose volume 8, Bulletins 4 to 8 compose volume 9, and Bulletins 9 to 11 compose volume 10. These publications are almost wholly of an economic nature.

The editions of bulletins are determined by the commissioners of public printing, but according to law shall consist of not less than 3,000 copies. They are distributed as stated on pages 113-114.

The cost of publishing is paid from the appropriation for State printing, and the Survey lacks data as to the actual figures. State printing is done under a contract, and the Survey has nothing to say as to who shall do the work. The engraver is generally designated by the supervisor of public printing, after competitive bidding. The quality of paper and the kind of binding are determined by the commissioners of public printing. The contents of the bulletins are left entirely to the State geologist.

The State geologist is authorized to purchase, repair, and sell publications of the Survey now out of print at prices which will cover the cost. Receipts from the sales go into the State treasury to the credit of the Survey. For the last three years these receipts were as follows: $1907, \$ 185.72 ; 1908, \$ 202.94 ; 1909, \$ 448.15$.

PRESENT LINES OF WORK.

Independent investigations.-The Survey is at present engaged in the following investigations:

Economic geology :

The Bremen oil field.

Peat deposits of Ohio.

Building stones of Ohio. 


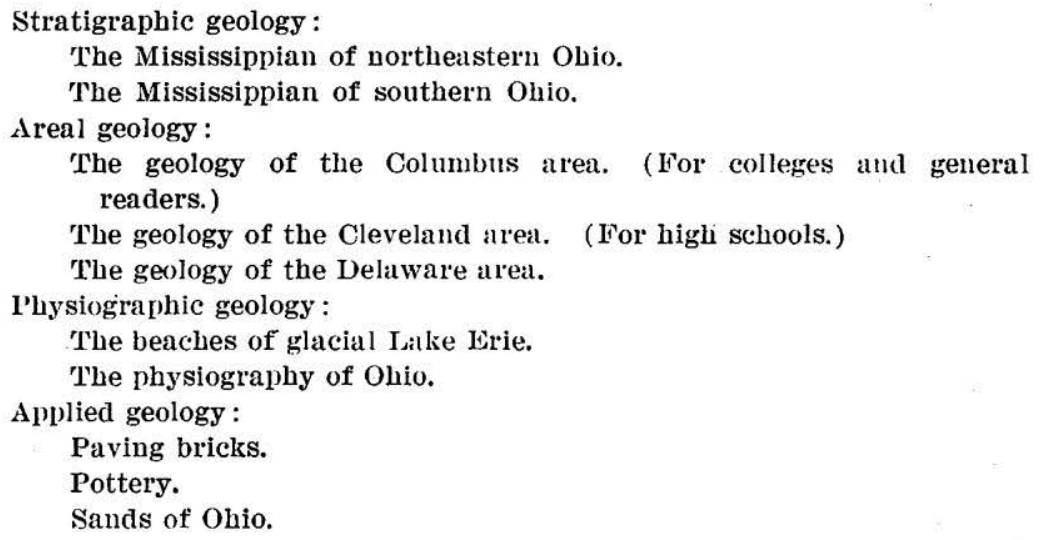

In addition to the foregoing, certain stratigraphic lines are being redrawn on topographic maps for use in future editions of the geologic map of Ohio.

Cooperation with United States Geological Survey.-At present the only cooperation with the Federal Survey is in the investigations of peat and of petroleum in southeastern Ohio. The samples are collected by the State Survey and the analyses are made by the Federal Survey.

\section{OKLAHOMA.}

\section{PREVIOUS SURVEY.}

In 1898 the Legislature of the Territory of Oklahoma established the Geological and Natural History Survey and appropriated for its maintenance $\$ 200$ a year. This amount was afterwards increased to $\$ 300$. Under the law the professor of biology at the State University of Oklahoma was ex officio Territorial geologist, the subject of geology, at that time, not being taught at the State University. Prof. A. H. Van Vleet, head of the department of biology, therefore became Territorial geologist in 1898 and served in that capacity until statehood was granted in 1907.

Considering the small amount of money available, the results of Prof. Van Vleet's survey were extremely satisfactory. Assisted by Charles N. Gould, geologist, and Paul J. White, botanist, work in the northern and western parts of Oklahoma was carried on each summer from 1901 to 1906 . As a result, two volumes were issued. The manuscript of the first biennial report was burned in a fire which destroyed Science Hall of the State University in 1903. The second biennial report was issued the same year and the third biennial report was issued two years later.

\section{PRESENT SURVEY.}

LEGAL DESIGNATION AND DATE OF ORGANIZATION.

The present organization is the Oklahoma Geological Survey; it was organized July $25,1908$. 
SUMMARY OF LAWS.

The authority for the establishment of the Oklahoma Geological Survey is contained in section 37 of article 5 of the constitution of Oklahoma, which reads as follows: "The legislature shall provide for the establishment of a State Geological and Economic Survey." The Survey was established by the first Legislature of Oklahoma under the following law:

SÉction 1. There is hereby created a bureau to be known as the Oklahoma Geological Survey, which shail be under the direction of a commission to be known as the State geological commission, composed of the governor, the president of the State University, and the State superintendent of public instruction.

SEc. 2. The said commission shall serve without compensation but shall be reimbursed for actual and necessary expenses incurred in the performance of their official duties. Said commission shall have general charge of the bureau and shall appoint as director of the Survey a geologist of established reputation, who may, with the approval of the commission, appoint such assistants and employees as may be necessary to carry out the provisions of this act. The director, assistants, and employees shall receive such salaries or compensation as may be determined by this commission.

SEc. 3. The said bureau shall have for its object and duties the following:

First, a study of the geological formations of the 'State, with special reference to its mineral deposits, including oil, coal, gas, asphalt, gypsum, silt, cement, stone, clay, lead, zinc, iron, sand, road-building material, water resources, and all other mineral resources.

Second, the preparation and publication of bulletins and reports accompanied with the necessary illustrations and maps, including both general and detailed descriptions of the geological structure and mineral resources of the State.

Third, the consideration of such other scientific and economic questions as in the judgment of the commission shall be deemed of value to the people.

SEc. 4. The director shall present to the governor a biennial report, ready for printing, showing the progress and conditions of said bureau, together with such other information as the commission may deem necessary: Prorided, That the commission shall have authority to print and to distribute said report.

SEc. 5. All materials collected, having served the purpose of the bureau, shall be deposited in the State Museum: Provided, That duplicates may be distributed to the various educational institutions of the State uncler such regulations as the commission shall formulate.

SEc. 6. In order to carry out the provisions of this act, it shall be lawful for all persons employed by the bureau to enter and cross all lands within the State: Provided, That in so doing, no damage is done to private property.

SEc. 7 . Until suitable laboratories, libraries, and testing apparatus are provided by the State for prosecuting the work of the Survey, said Survey shall be located at the State University. The commission shall enter into arrangements with the board of regents of the State University for the use, by members of the staff of the Survey, of such rooms, laboratories, libraries, and apparatus as may be necessary for the carrying on of such work.

SEC. 8. The sum of $\$ 15.000$, or so much thereof as may be necessary, is hereby appropriated out of the funds in the State treasury, not otherwise appropriated, to provide for the payment of actual expenses of the commission. 
and for other expenses authorized by them, and for the salaries or other compensation of the director, assistants, or other employees.

Skc. 9. For the preservation of the public peace, bealth, and safety, an emergency is hereby declared to exist by reason whereof this act shall take effect and be in force from and after its passage and approval.

\section{ORGANIZATION.}

Under the law the governing board of the Survey is the State geological commission, which is composed of the governor, who is president of the commission; the State superintendent of public instruction, who is secretary of the commission; and the president of the State University, who is the executive officer of the commission.

The following paragraphs set forth the duties of the officers:

The executive officer is empowered to certify to the State auditor the amount of money required to pay the salaries of the director and other expenses as may be authorized by the commission.

The executive officer is empowered to arrange with the board of regents of the State University for such rooms, laboratories, libraries, and testing apparatus as may be necessiry for the work of the Surrey, as provided in section 7 of the act establishing the Survey.

The president of the commission is to make known to the Director of the United States Geological Survey, in Washington, and to heads of the geological surveys in the neighboring States the organization of the Oklahoma Geological Survey, and to ask their official aid and cooperation.

The director of the Survey is authorized in the name of the commission to solicit the friendly aid and cooperation of all the citizens of Oklahoma, and particularly all teachers and other professional men of the State.

In conformity with article 3 of section 3 of the act establishing the commission, the executive officer is authorized on the advice of the director to appropriate such funds of the Surrey as he may think wise to the investigation of zoological and botanical problems of the State.

The executive officer is anthorized to apportion the funds of the Survey, to approve the appointment of assistants and other employees, and to see that the instructions of the commission are faithfully carried out.

The members of the commission, being State officials, do not draw additional salaries.

The active work of the Survey is in charge of the director, who is appointed by the commission. The present incumbent is Charles $\mathrm{N}$. Gould, who was appointed July 25, 1908. The term of office is indefinite. The compensation, which is fixed by the commission, is an annual salary of $\$ 2,500$.

The clerical force consists of one clerk and two stenographers, appointed by the director and the appointments approved by the executive officer. The salaries range from $\$ 30$ to $\$ 50$ a month. Up to the present time students in the State University have been employed in this capacity. In general, student help has been found very satisfactory. 
The geologic assistants consist of an assistant director at a salary of $\$ 1,500$ a year, a chemist at a salary of $\$ 1,200$ a year, a draftsman at $\$ 900$ a year, and assistant geologists, usually professors in the State University of Oklahoma, or other schools of equal rank, who serve at salaries varying from $\$ 75$ to $\$ 125$ a month. Field assistants, chiefly students at the university or members of the faculty in the State normal schools, receive salaries ranging from $\$ 20$ to $\$ 30$ a month in addition to their expenses while in the field. All assistants are appointed by the director subject to approval by the executive officer:

\section{APPROPRIATIONS.}

The appropriations for the Survey are made biennially by the legislature. Estimates for the work of the Survey for two years are prepared by the director and submitted by the executive officer to the state auditor, who lays the matter before the chairman of the appropriation committee. Appropriations thus far have not been contingent on cooperation, but it is hoped that such appropriation may be made at the coming session of the legislature.

Unexpended balances lapse into the State treasury at the end of the fiscal year. The annual appropriations for the Survey for the year ending June 30, 1910, were as follows:

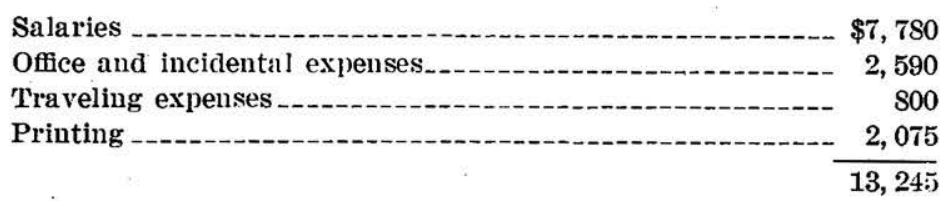

The annual appropriations for the biennium ending June 30, 1913, are as follows:

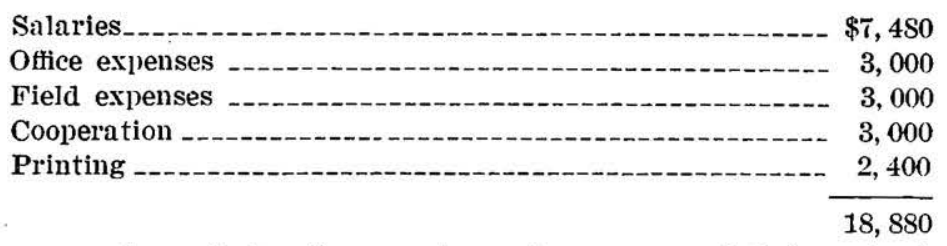

The energies of the Survey have been expended largely in the preparation of bulletins on economic resources. Particular attention has been paid to oil, gas, asphalt, coal, clays, road material, Portland cement, lead, zinc, gypsum, and salt. Bulletins on these subjects have either been submitted for publication or are in course of preparation. In addition to the economic reports, a small amount of stratigraphic work has been carried on. The chemical laboratories are being fitted for the analysis of water and of mineral specimens. Considerable time is given to the investigation of road materials, 
but none to highway work. No topographic work nor investigations of the underground water resources have been undertaken.

Two lines of work which bid fair to become extremely popular in Oklahoma have been undertaken by the Survey. The first is the preparation of an exhibit of the mineral resources of the State for the Oklahoma State fair, and the second is the collection of mineral specimens for the high schools, normal schools, and small colleges in the State. The Survey has assembled well-classified and comprehensive collections of 75 specimens of the rocks, fossils, and minerals of Oklahoma, and these are loaned to the schools. About 50 sets have already been sent out and applications are on file for a number of others.

The Survey is constantly in receipt of requests asking for a member of the staff to examine certain localities with a view to ascertaining the probabilities of minerals being found there. It has been found impossible to comply with all requests which have come to the office, and the petition plan has been adopted. The following blạnk is sent out to each applicant:

To the Director of the Oklahoma Geological Survey:

Oklahoma,

We, the undersigned freeholders of the county of State of Oklahoma, do hereby- petition that a competent geologist be sent to this county to examine and report upon the following-described lands, to wit:

We have reason to believe the following minerals may be found upon these lands :

When a petition is signed by 50 taxpayers of a community and is certified by the county clerk a member of the Survey visits the locality, makes an examination, and submits. a report thereon.

\section{PUBLICATIONS.}

Up to the present time the Survey has published only one bulletin, entitled "Preliminary report on the mineral resources of Oklahoma,". but the following additional bulletins are either in press or ready for submission to the printer: "Preliminary report on asphalt," "Mineral resources of the Arbuckle Mountains," and "Preliminary report on coal."

The edition of the Survey publications is 3,000 copies. The size of the page is 6 by 9 inches.

The bulletins are distributed free of charge, except that in some cases extra postage is requested. The Survey having been organized for only two years, it is impossible to give the average cost of printing 
reports and maps. The appropriation for printing for the present biennium is $\$ 4,175$.

The contract for printing must be let by the State board of public affairs. The specifications, as to the style of report, illustrations, contents, etc., are prepared by the Survey. Bids are requested and the contract is awarded to the lowest bidder. If the appropriation is not sufficient to cover the cost of publication according to the specifications it is necessary to reduce either the number of illustrations or the number of copies to be issued.

The Survey has full control over the distribution of reports. Its policy is to distribute them, first, to other State surveys and to scientific organizations throughout the world; second, to manufacturers and business men particularly interested in the subject matter of the report; and third, to newspapers and prominent citizens of the State. In this connection it may be said that the issue of 3,000 copies of Bulletin 1 is practically exhausted.

\section{PRESENT LINES OF WORK.}

\section{INDEPENDENT INVESTIGATIONS.}

The Oklahoma Geological Survey is devoting its energies chiefly to investigations of the mineral resources of the State. During the last two years the oil and gas fields, clays, building stones, and structural materials have been studied. At present the coal, gypsum, glass sand, salt, lead, and zinc resources are receiving attention.

\section{COOPERATIVE INVESTIGATIONS.}

United States Geological Survey.-At present the Oklahoma Survey is cooperating with the Federal Survey in the preparation of a geologic folio covering the Nowata and Pawhuska quadrangles. The Pawhuska quadrangle was surveyed by the Federal organization in 1909 ; the Nowata quadrangle was surveyed in 1910, under the direct supervision of Prof. D. W. Ohern, of the department of geology at the Oklahoma State University.

United States Office of Public Roads.-The Oklahoma Survey has cooperated with the United States Office of Public Roads at Washington in collecting and testing samples of road-building materials. An engineer detailed by the Roads Office spent several weeks in company with the chemist of the Oklahoma Survey investigating the roadbuilding materials of the State. The tests of these materials have been made in the laboratories at Washington and the reports have been properly distributed.

Other State geological surveys.-Up to the present time the only cooperation with the geological surveys of other States has been with the Kansas Geological Survey. Prof. J. W. Beede, who has 
worked on the Permian problem in that State for a number of years, has spent some time in Oklahoma studying the rocks of this interesting series. It is hoped that during the coming year cooperation may be carried on with the Missouri and Arkansas surveys.

Other scientific bureaus of the State.-Cooperation with the Oklahoma State Board of Agriculture and the park boards and watersupply commissions of the cities of Oklahoma has been arranged for and in several instances carried out. The people of Oklahoma are learning to look more and more to the Survey for accurate data regarding the State's natural resources.

\section{PENNSYLVANIA.}

\section{PREVIOUS SURVEYS.}

FIRST GEOLOGICAL SURVEY.

Through the instrumentality of the Geological Society of Pennsylvania an act providing for a Geological Survey of the State was reported to the legislature in 1832 , but failed to pass. It was resuhmitted annually for several years, and each year received the same treatment until, under the urgent demands of the people, the legislature passed it May 29, 1836. The act authorized an annual appropriation of $\$ 6,400$ for five years. Prof. Henry Darwin Rogers, formerly State geologist of New Jersey, was appointed State geologist. During the first year the general geologic features of the State were determined and the Paleozoic section was divided into 12 formations, numbered from I to XII. This numerical nomenclature was used in the Pennsylvania publications for many years. No. I was the limestone at Harrisburg and No. XII the coal measures. In this first year also an understanding was obtained of the anticlinal and synclinal folds which are so conspicuous a feature of the geology of the State.

In the second year of the Survey detailed work was begun in the anthracite region, and in the third year nine assistants were scattered over the State, each man assigned to a district. This third season's work resulted in the discovery that the coal measures of western Pennsylvania are divided into two series, and that the bituminous coal field is characterized by folds and basins, but with a simpler structure than those in the central part of the State.

The Survey continued its work until 1841, but as the people could not see that they were getting what they wanted out of it, the legislature failed to make an appropriation in 1842. For three years, however, Mr. Rogers continued to prepare reports without remuneration from the State. In 1848 he submitted a final report, but it was not until 1851 that publication of the report was anthorized. The 
work being then 10 years old the legislature made an appropriation to cover the cost of the field work necessary to bring the report up to date and to defray the expense of its publication. From 1851 to 1854 field work was carried on each season, but it was not until 1858 that the final repòrt of the Survey appeared. It consists of two quarto volumes, containing 1,631 pages, with numerous illustrations.

The publications of the first Geological Survey consisted of six annual reports, dated from 1836 to 1842 , and the aforementioned final report.

SECOND GEOLOGICAL SURVEY.

A bill authorizing the inauguration of a new State Survey and the appointment of a board of commissioners passed the legislature May 14, 1874. The board selected the professor of geology in the University of Pennsylvania, J. P. Lesley, for State geologist. As a reconnoissance geologic survey of the entire State had already been made and the general geology was known with a fair degree of accuracy, the problems to be undertaken under Lesley's direction were well understood and plans were wisely formulated. The new Survey was to study the details of special geologic problems or special areas rather than the broad geologic features of the entire State. The principal work of the organization was the solution of economic problems, particularly of structural details and of the extent of the coal and petroleum formations. The plans adopted provided for (1) the occupation of five specially important and hitherto little-studied districts of the State requiring immediate attention; (2) the postponement of work in the best-known anthracite and bituminous coal regions; (3) the postponement of extensive systematic study of fossils; (4) the establishment of a special laboratory at Harrisburg for the analysis of irons, steels, iron ores, and other blast-furnace stock; (5) the preparation of a special report on petroleum; (6) the preparation of a special report on the mineralogy of the State; ( 7 ) the publication of the results of the summer's work during the fol. lowing winter; and (8) the exhibition of type specimens of the Survey collections in the rooms of the board at Harrisburg.

During the 13 years that the Second Survey existed annual appropriations were made which amounted to $\$ 545,000$. Among those who were regularly employed, or undertook special investigations in association with Prof. Lesley, were C. A. Ashburner, C. E. Beecher, J. C. Branner, J. F. Carll, H. M. Chance, E. W. Claypole, E. V. d'Invilliers, L. G. Eakins, Persifor Frazer, F. A. Genth, C. E. Hall, T. Sterry Hunt, A. E. Lehman, Leo Lesquereux, A. S. McCreath, F. Prime, jr., J. J. Stevenson, I. C. White, Arthur Winslow, and G. F. Wright. 
Work was prosecuted over the whole State, particular attention being given to the oil region, the bituminous coal fields, and the anthracite fields. The anthracite fields were the subject of most exhaustive studies, detailed topographic maps being made on which the geology was laid down with the greatest care. Of this work David White says: "The atlas of the southern anthracite field in Pennsylvania represents the most minutely detailed and most excellent economic work of sedimentary deposits that has yet been accomplished over an extensive area in this country."

The reports of Lesley and his associates were published as rapidly as they could be prepared, and proved of such value to the public that the Survey maintained popular favor and continued to receive appropriations until 1887. The results of the 13 years of the Second Survey are contained in 77 octavo volumes of text, with 35 atlases, and " grand atlas." These were followed, in 1893 and 1895, by the three octavo volumes constituting the final report, with the publication of which the Second Geological Survey came to an end. The black cloth-bound volumes of this Survey are a familiar sight in geologic libraries, but the State no longer has any of these reports for distribution. They can be obtained only from dealers in secondhand books. These volumes are designated by letters and figures. The letters seem to denote the sequence of inception of work in different areas, or different problems, and the figures or repeated letters indicate the order of subsequent reports on the same area. All volumes bearing the same letter relate to a particular area. For instance, all volumes lettered " $\mathrm{G}$ " deal with the northeastern part of the State, and those lettered " $K$ " discuss the southwestern part. The sequence "G," "G2," "G3," to "G7" shows the chronologic order of completion of the reports. The " $\mathrm{G}$ " report was begun after the " F" report, but the "G7" report was completed before the "FF" or-"F2" report. Atlases are indicated by parentheses surrounding the letter; thus "G3" designates the text of a report on Lancaster County and "(G3)" the atlas to accompany it. For ready reference to the reports it is necessary to consult an index map, usually found in the front of each volume, showing the letters designating reports on different parts of the State.

\section{PRESENT SURVEY.}

IJEGAL DESIGNATION AND DATE OF ORGANIZATION.

The present Survey is entitled the Topographic and Geological Survey. It was organized under laws of 1899 and 1909.

SUMMARY OF LAWS AND ORGANIZATION.

The present survey was established in 1899 , by an act of the legislature entitled "An act to authorize the topographic and geological 
survey of the State in cooperation with the United States Geological Survey," which reads as follows:

Secrion 1. Be it enacted, etc., That the governor be, and he is hereby, authorized to appoint a commission, to consist of three citizens of this State, to confer with the Director or representative of the United States Geological Survey and to accept its cooperation with this State in the preparation and completion of a contour topographic and geological survey and map of this State, which is hereby authorized to be made. Said commission shall serve without pay, but all its necessary expenses shall, on approval by the governor, be paid out of the State treasury. Said commission shall have power to arrange with the Director or representative of the United States Geological Survey concerning this survey and map, its scale, method of execution, form, and all details of the work, in behalf of this State, and may accept or reject the work executed by the United States Geological Survey. And it is hereby provided that said map shall accurately show the outlines of all townships, counties, and extensive wooded areas in this State, as existing on the ground at the time of the execution of these surveys; the location of all roads, railroads, streams, canals, lakes, and rivers; and shall show by contour lines the elevation and depression of the surface of the country, also location of coal, oil, natural gas, and clay-bearing formations.

SEc. 2. For the prosecution of this survey, the sum of $\$ 20,000$ is hereby appropriated for the year 1899 and $\$ 20,000$ for the year 1900; and the auditor general is hereby authorized to draw his orders on the State treasury for such portions of these amounts as may be required, from time to time, from money in the treasury not otherwise appropriated, upon vouchers signed by two mentbers of the commission; but it is hereby provided that these expenditures shall not be in excess of the amounts expended upon the same work by the United States Geological Survey from its own funds. The commission shall report to the governor each year. For the purpose of making the surveys hereinbefore provided for, it shall be lawful for the persons employed in making the same to enter upon all lands within the boundaries of this State, but this act shall not be construed as authorizing any unnecessary interference with private rights.

Src. 3. This act shall be in effect immediately upon its passage.

Approved April 28, 1890.

The principal object contemplated by the act was the preparation of a topographic map of the State. The governor appointed as the commission G. W. McNees, Simon Harrold, and Fred D. Barker, whe entered into the following agreement with the Director of the United States Geological Survey:

Agreement between the Topographical and Geological Survey Commission of the State of Pennsylvania and the Director of the United States Geological Survey, for the cooperative topographic and geologic survey of the State.

1. The preparation of the maps shall be under the supervision of the Director of the United States Geological Survey, who shall determine the methods of survey and map construction, in accordance with the act of assembly of the State of Pennsylvania, entitled "An act to authorize the topographic and geologic survey of the State in cooperation with the United States Geological Survey," approved April 28, 1899.

2. The order in which in point of priority different parts of the State shall be surveyed shall be agreed upon in detail between said commission and said Director. 
3. The work shall be based upon the triangulation of the United States Coast and Geodetic Survey, and, wherever this triangulation is deficient, it shall be supplemented by said cooperative survey.

4. The survey shall be executed in a manner sufficiently elaborate to prepare a topographic map upon the scale of 1:62,500 exhibiting the hydrography, hypsography, and public culture; said survey and map shall accurately show all township and county boundary lines (as established by the State laws at the time of their completion) and extensive wooded areas in this State as existing on the ground at the time of the execution of these surveys; the location of all roads, railroads, streams, canals, lakes, and rivers, and shall show by contour lines the elevation and depression of the surface of the country, also on geologic maps, the location of the coal, oil, natural gas, clay-bearing, and other geological formations. The said topographic maps shall be similar to the sheets already completed in this State, and the form of the final publications of the geological maps shall be the same as the Geological Atlas of the United States Geological Survey.

The preliminary field maps shall be on such a scale as said Director shall select to secure accuracy in the construction of the final map.

5. It is understood and agreed upon that the geological work shall follow the topographic survey as closely as consistent with economy and in accordance with modern scientific methods. The time of beginning this work to be agreed upon between the State Survey Commission of Pennsylvania and the United States Geological Survey.

6. The hypsography shall be shown by contour lines with vertical intervals of 20 feet, and the leights of important points shall be determined and marked upon fixed and permanent bench marks in important and prominent places throughout the counties; also, correct meridian points shall be located at each county seat and records furnished to the said commission.

7. For convenience, the United States Geological Survey shall, during the progress of the field work, pay the salaries of the persons employed therein, while the traveling, subsistence, and field expenses shall be paid for the same time by the State. For office work on the map the salaries shall be divided between the two agreeing parties in such a way as to equalize all expenses, provided that the total cost to the State of Penusylvania of the field and office work and expense of said commission for the year 1899 and 1900 shall not be more than $\$ 40,000$, and provided that the United States Geological Survey shall expend an equal amount.

8. During the progress of the work free access to the field sheets and records of the topographer's and draftsmen shall be afforded the State commissioners for examination and criticism; and should they deem that the work is not being executed in accordance with this agreement, then the said commissioners may, on formal notice, terminate this agreement.

9. The resulting maps shall fully recognize the cooperation of the State of Pennsylvania.

10. As the work is completed, the State commissioners shall be furnished by the United States Geological Survey with photographic copies of the manuscript sheets; and, when the engraving. which is to be done at the cost of the United States Geological Survey, is completed, and at all times thereafter, when desired, the said commission shall be furnished by the said Survey with transfers at cost of printing from the copper plates of the photographic sheets for use in printing editions of said maps.

Washington, D. C., July 12, 1899. 
Under the conditions of the foregoing act and agreement work progressed until half of the State has been mapped topographically and 37 quadrangles have been surveyed geologically, either by the Federal Survey alone or in cooperation with the State. Folios and bulletins descriptive of the geology of several of these quadrangles have been published by the United States Geological Survey.

In 1909 the legislature passed the following act:

An act authorizing the Topographic and Geological Survey Commission of Pennsylvania to establish and maintain a Topographic and Geological Survey of the State, fixing salaries, providing for the printing and binding of the results of said Survey, the furnishing of supplies and stationery, and making an appropriation therefor.

Section 1. Be it enacted by the senate and house of representatives of the Commonwealth of Pennsylvania in general assembly met, and it is hereby enacted by the authority of the same, that the Topographic and Geological Survey Commission of Pennsylvania is hereby authorized to establish and maintain a Topographic and Geological Survey of the State.

Sec. 2. The object of such Survey shall be as follows: The preparation and completion of a topographic map or maps of the State, also the study of its geological formation, with special reference to the economic development of its resources, such as coal, ores, oil, gas, stones, cement material, and all other minerals.

With these ends in view, the said Commission may and is hereby authorized to arrange with the United States Geological Survey or such other national organization as may be authorized to do such work for its cooperation, provided that the amount of money to be expended in such cooperative work on behalf of the State shall not exceed the amount so expended by such national organization.

The preparation of reports, with the necessary geological and other maps to properly illustrate the same, which shall be of such detail character and style of publication as the said Commission may deem best suited to properly describe the resources of the State.

SEc. 3. The reports of the said Survey shall be printed by the department of printing and binding in such form and style as may be designated by the Topographic and Geological Survey Commission.

SEc. 4. The said Commission shall serve without pay except the chairman of the same, who shall receive a salary of not more than $\$ 1,500$ per annum, and the necessary expenses of said Commission shall be paid out of the State treasury after the same have been submitted in itemized form to the auditor general and approved by him.

SEc. 5. The said Commission shall appoint a State geologist, who shall be in immediate charge of the work of said survey. subject to the regulations and orders of said Commission.

The said geologist shall receive a salary not to exceed $\$ 3,000$ per annum. He may also appoint such assistants as in the judgment of such Commission may be proper and necessary.

SEc. 6. In addition to the reports hereinbefore authorized, the said Commission shall make a biennial report to the governor and the legislature showing the progress and condition of the work, together with such other information and recommendations as the said Commission may deem necessary and useful. 
Skc. 7. All specimens and materials collected shall, after serving the purposes of the Survey, be deposited in the State Museum and there preserved in such form as to be available for study in the further work of the Survey, or by individual students, but must not be removed from said Museum except for study and use by the State geologist or those working under his direction.

SEc. 8. All supplies and stationery, blank books, forms, or other printed ${ }^{\text {. }}$ matter necessary for the use of said Survey shall be furnished by the denartment of printing and binding or the department of public grounds and buildings upon requisition of said Commission.

SEc. 9. It shall be lawful for any and all persons employed in carrying on the work of the said Survey to enter unon and cross all lands within the State, provided that in so doing no damage shall be done to private property.

SEc. 10. The sum of $\$ 35,000$ annually [afterward changed to $\$ 10,000$ annually, or a total of $\$ 20,000]$ for the term of two years is hereby appropriated for the use of said Commission in carrying on the work authorized by this act.

SEo. 11. This act shall be in effect on the 1st day of June, 1909.

SEc. 12. All laws or parts of laws inconsistent with this act are hereby repealed.

This act of 1909 authorizes the State Topographic and Geological Survey Commission to do topographic and geologic work independently of the United States Geological Survey. On its passage the Commission appointed Richard R. Hice, of Beaver, as State geologist, and he still retains the position. Cooperation with the Federal Survey in topographic work has been continued, but geologic work is now being done independently.

The personnel of the Topographic and Geological Survey Commission in 1910 was as follows: G. W. McNees, of Kittanning (chairman); A. S. McCreath, of Harrisburg; and E. V. d'Invilliers, of Philadelphia.

During the first year of the organization under the new act (190910) permanent assistants were not appointed, the work being done on a per diem basis. So far as possible, college professors and advanced students who are residents of the State are employed in the work. Appointments are made by the State geologist. There is no civil-service commission to provide an eligible list or impose restrictions. In 1909 and 1910 the State geologist employed five geologists and two clerical assistants.

\section{APPROPRIATIONS.}

Appropriations are biennial and unexpended balances do not carry over. The total appropriation for the biennium 1909-1911 was $\$ 20,000$, or $\$ 10,000$ annually, about half the usual appropriation, and as it was to cover all topographic and geologic work the progress of the Survey has been greatly retarded. More than half of the sum was expended in cooperative topographic work. 
The appropriation which is asked for by the Commission for the next biennium will be divided as follows:

$\begin{array}{ll}\text { Administration and routine work } & \text { Per cent. } \\ \text { Topography (in cooperation with United States Geological } & \\ \text { Survey) } & \\ \text { Economic, stratigraphic, and areal geology } & \\ \text { Water resources, stream flow, etc- } & \end{array}$

It is not at present intended to do any work on statistical geology, on paleontology as distinct from stratigraphy, or on the drainage of flooded districts. Chemical work will be included under geology. Highway work, testing road materials, and other technologic investigations are not contemplated for the coming year.

\section{PUBLICATIONS.}

The Commission proposes to publish three kinds of reports-(1) a series of biennial reports to the legislature giving a statement of the work accomplished and probably accompanied by short scientific papers (three of these biennial reports have been issued); (2) detailed reports on special subjects; and (3) short bulletins on special subjects. No reports of the second and third classes have been published.

Practically all geologic work done since the establishment of the Commission in 1899 has been in cooperation with the United States Geological Survey, and the reports have been published by that bureau.

The printing of State Survey publications must be done by the department of printing and binding, and while they conform in a general way to other State publications, the form and style are left to the Commission. The cost of printing reports does not come from the Survey appropriation and the department of printing and binding furnishes all supplies, such as stationery, blank books, forms, and other printed matter, on requisition of the Commission.

Reports are sent as exchanges to other surveys and organizations and are distributed to educational institutions and libraries within the State, and to citizens to whom they are of interest. Distribution is free, except postage in some cases.

Seven more or less detailed reports are in process of publication, in addition to two oil and gas reports resulting from cooperative work. These include papers on talc and serpentine in Pennsylvania, preliminary investigation of the cement resources and industry of Pennsylvania, graphite in southeastern Pennsylvania, paint ores of the State, and relation of the fresh-water fauna to geologic development, and a bibliography of Pennsylvania geology. 
PRESENT LINES OF WORK.

Topographic work is being done in cooperation with the United States Geological Survey, and also geologic work on a number of quadrangles. There is at present no other cooperation with National or State bureaus. The geologic work being done by the Survey independently is chiefly of an economic nature.

\section{RHODE ISTAND.}

\section{HISTORICAL SUMMARY.}

In the later part of the thirties the increasing desire of the people to know more about the natural resources of the States culminated in Rhode Island in the formation of a State Survey which, in common with the times, was both geologic and agricultural in its purpose. The organization of this Survey was largely due to the efforts of the Rhode Island Society for the Promotion of Domestic Industry, which in December, 1838, appointed four men to confer with the committee appointed by the general assembly and appropriated $\$ 500$ of the society's funds, provided the State should appropriate the balance necessary to conduct a survey of the State. Accordingly, at the session of the general assembly in 1839 a resolution appropriating $\$ 2,000$ was passed, this sum to be expended under the direction of a committee of six from the general assembly and four from the Rhode Island Society for the Promotion of Domestic Industry. The members of this committee were to serve without compensation.

Dr. Charles T. Jackson, geologist of the State of Maine and member of many scientific societies both here and abroad, was asked to make the survey, and the contract with him was signed in April,1839. His report, a volume of 312 pages, accompanied by map and geologic section sheet, was submitted to the committee May 25, 1840, and was published the same year. Criticism on the basis of our present geologic knowledge should not be made of the work done at that time. This report delimited the areas of the sedimentary and crystalline areas of the State, except where there had been considerable regional metamorphism, which was an unknown field to the geologists of that period.

In 1868 Prof. Thomas H. Ridgeway presented to the house of representatives a memorial upon the economic value of the so-called "Cranston" coal beds, recommending the construction of iron blast furnaces and the utilization of the natural resources of the State.

In January, 1875 , a resolution was passed authorizing the governor to appoint a commission of five, three from the general assembly and two from the Providence Franklin Society, to prepare a plan for a thorough geologic and scientific survey of the State, to make esti- 
mates, and, if possible, to report to the next general assembly. The expenses of this committee were to be paid from an appropriation of $\$ 500$. This committee recommended to the general assembly the following plan:

1. The formation of a permanent board to have charge of the survey.

2. The appropriation of $\$ 5,000$ annually for four years to complete the topographic plane tables of the State.

3. The publication of a map on the scale of $1: 40,000$.

4. A geologic survey of the State to be made under the direction of an able geologist appointed by the board, according to plans to be decided upon by it hereafter.

5. A further survey of the natural history of the State to be recommended to the general assembly after the completion of the geologic survey.

6. The submission to the general assembly of an annual report.

There is no record of any action taken on the report of this commission. Apparently those interested in the geologic survey of Rhode Island were so discouraged by the failure of this last attempt that there is no record of anything further being done for about 20 years.

Topographic surveys of the State and coast surveys of Narragansett Bay were published from the time of the settlement, through the Revolution, and up to 1892. Dr. Jackson, however, was obliged to rely on a coast-survey chart of Narrangansett Bay, published by the Hydrographic Branch of the Navy, 1832; the Stevens map of the State, published in 1831; and Nelson's survey of Cumberland, published by Aaron White. The need for a topographic map of the State was apparent. Many disputes were centered about the question as to the highest point in Rhode Island, Mount Hope, with an altitude of 200 feet, having the largest number of supporters, though hills in the western uplands are now known to be much higher. The matter was brought to the attention of the general assembly at its session in 1888 by a bill which provided for the appointment by the governor of three commissioners, "citizens of the State qualified by education and experience for such a survey," to serve without compensation, but to be provided with funds for their necessary expenses. This commission had the power of conferring with the United States Geological Survey regarding the completion of a contour topographic map, and a sum not to exceed $\$ 5,000$ was appropriated in addition to the necessary expenses. The additional sum of $\$ 3,500$ was appropriated in April, 1889, and $\$ 1,000$ in April, 1891, for the preparation and publication of a wall map and atlas. Of each appropriation more than $\$ 100$ was returned to the State treasury as an unexpended balance.

In May, 1895, the general assembly appointed a committee of four to provide for a geologic survey of the portions of the State contain- 
ing rocks adapted to road making, and the sum of $\$ 1,000$ was appropriated for that purpose. Frederick P. Gorham, then a graduate student at Brown University, was selected to do this work, and he prepared a sketch geologic map of the State and three sets of specimens illustrating the different rock types in Rhode Island. No report of this work, however, was ordered printed by the legislature.

In 1904 a bill was introduced into the general assembly providing for a geologic survey, $\$ 3,000$ to be appropriated for the purpose, but the bill was not reported back to the house from the committee to which it was referred.

In 1908 a bill providing for a geologic survey of Rhode Island was prepared by former Lieut. Gov. F. H. Jackson. A hearing was given on this bill, but it did not pass the general assembly.

The following year a law was enacted making provision for the present Natural Resources Survey of Rhode Island and appropriating $\$ 2,500$ annually for three years for its use. The work was placed under the general charge of the commissioner of industrial statistics, where it remained until August, 1910, when it was placed under the direction of the newly created Conservation Commission.

\section{PRESENT SURVEY.}

LEGAL DESIGNATION AND DATE OF ORGANIZATION.

The present organization is the Natural Resources Survey of Rhode Island; it was organized under laws of May 10, 1909, and August, 1910.

SUMMARY OF LAWS.

Chapter 438 of the public laws of the State of Rhode Island, 1909, passed May 7, 1909, and signed three days later, is as follows:

SECTION 1. A survey of the natural resources of the State shall be made. This survey shall be placed under the general charge of the bureau of industrial statistics, in cooperation with the Rhode Island State College and the Government of the United States of America.

SEc. 2. The bureau shall appoint a competent agent to take charge of the survey, at such compensation as the commissioner of the bureau may determine. The agent so appointed may employ suitable assistants as they may be needed for the proper prosecution of the work of the survey, with the advice and consent of the commissioner of the bureau.

SEc. 3. The survey shall be made so as to embrace the following matters, viz:

1. An examination of the geological formation of the State, with special reference to its economic resources, viz, road material, building stones, clays, coals, and other mineral substances.

2. A detailed examination and elassification of the soils, and a study of their adaptability to particular crops, together with an examination of the waste lands of the State, and the bearing it may have upon water powers, potable waters, and the relation of deforested areas to such water supplies. 
3. An examination of the physical features of the State, with reference to their practical bearing upon the occupation of the people.

4. The preparation of special geological and economical maps to illustrate the resources of the State.

5. The preparation of special reports, with necessary illustrations and maps, which shall embrace both a general and detailed description of the geological and natural resources of the State.

6. A report upon the fishery industry of Narragansett Bay and its tributary waters.

7. The consideration of such other scientific and economic questions as in the judgment of the commissioner and the Rhode Island State College shall be deemed of value to the people of the State.

SEc. 4. An annual report of progress to be made to the general assembly, or upon their request.

SEc. 5. Reports and maps to be printed by direction of the commissioner upon recommendation of agent and the Rhode Island State College; to be distributed or sold by said commissioner; moneys to be returned to State treasury.

SEc. 6. Distribution of material collected; to be finally distributed by the commissioner and the Rhode Island State College to the educational institutions of the State, or placed upon permanent exhibition.

SEc. 7. An annual appropriation of $\$ 2,500$ for a period of three years to be paid by the State upon itemized vouchers approved by the governor.

SEc. 8. This act shall take effect upon its passage.

The following bill (chapter 644, public laws of Rhode Island) became a law during the August session, 1910, and the general charge of the Survey passed from the commissioner of the Bureau of Industrial Statistics to the State Conservation Commission, but practically without change in the administration of the Survey.

SEcrion 1. There shall be a State Conservation Commission of five members, consisting of the Commissioner of Industrial Statistics, the director of the Rhode Island Agricultural Station, the secretary of the State Board of Agriculture, the commissioner of forestry, and the secretary of the Metropolitan Park Commission of the Providence Plantations, ex officio, and their respective successors.

SEc. 2. Said Commission shall have general supervision and oversight of the matters pertaining to the conserration of the natural resources of the State, including the Natural Resources Survey established and authorized by chapter 438 of the public laws, passed at the January session, A. D. 1909, and shall act in an-advisory capacity to the undertakings of this nature now in progress or which may hereafter be projected, provided same are not inconsistent with the law. It shall have authority to cooperate with similar commissions of other States and with the departments of the United States Government with which it may have occasion to enter into negotiations whenever it shall deem it advisable.

Section 3 provided for the organization of the Commission. In section 4 the main purpose of this Commission is stated. It is to make a census and list of the so-called "abandoned farms." The further powers of the Commission were rather comprehensive and include many lines of work already given to the State Survey. In section 5 
the sum of $\$ 3,000$ was appropriated. Section 6 provided that the Commission was to report on abandoned farms in January, 1911. Section 7 states that the Commission shall serve without compensation, except expenses.

SEC. 8. This act shall take effect upon its passage, and all other acts or parts of acts inconsistent therewith are hereby repealed. Nothing in this act shall be considered, however, as repealing or otherwise affecting any of the provisions of chapter 438 of the public laws of 1909 (creating the Natural Resources Survey) except as provided in section 2 .

ORGANIZATION.

The governing board is the State Conservation Commission, information regarding which is given under "Summary of laws."

The executive officer is called superintendent. Prof. Charles W. Brown, head of the department of geology at Brown University, is the present incumbent. He was appointed by the commissioner of industrial statistics, who formerly had charge of the Survey, in June, 1909. His compensation is at a per diem rate and is fixed by the Commission. He devotes the summer months to field work for the Survey and a month or more of the college year to office work for the Survey.

Occasional clerical and stenographic assistance is employed by the superintendent, with the advice and consent of the Commission. There are no civil-service regulations, the only requirement being general fitness for the work. The compensation varies from $\$ 1$ to $\$ 3.50$ a day. The total amount of this sort of assistance would probably equal that of one person for half a year.

The geologic assistants are instructors or advanced college students at Brown University, who are employed for varying periods. Their compensation ranges from $\$ 1$ a day to $\$ 75$ a month and field expenses.

The only topographic work done by the Survey is the drafting of enlargements of existing topographic maps. No engineering work has been undertaken. Work on the water resources is done in cooperation with the United States Geological Survey.

\section{APPROPRIATIONS.}

The law of 1909 appropriated the sum of $\$ 2,500$ annually for the period of three years, to be used for the purposes specified in the law. The average expenditures are about as follows:

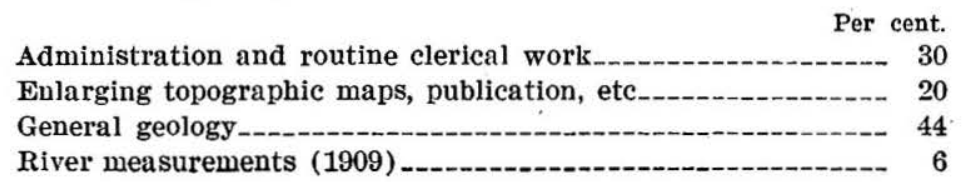


PUBLICATIONS.

The only publication thus far has been Bulletin 1, a preliminary report giving in outline some of the data gathered, especially with reference to the water resources and coal. One thousand copies of this report were issued for free distribution.

The cost of the printing does not come from the Survey appropriation. The printing and distribution of publications is left to the superintendent and the commission.

The mailing list includes the State libraries, State surveys, departments of geology in prominent educational institutions, and interested persons.

\section{PRESENT LINES OF WORK.}

The present lines of work include a detailed classification of the occupied and unoccupied lands of Rhode Island, especially in the "abandoned areas;" the preparation of a detailed geologic map of the State; the publication of a series of educational bulletins on the geography, geology, and water resources of Rhode Island; and a comprehensive and detailed study of the soils of the State.

\section{SOUTH CAROLINA.}

PREVIOUS SURVEYS.

To South Carolina belongs the credit of having been among the first States to organize a State Geological Survey. Since the first Survey, which was authorized by the legislature in 1824, the statutes of the State have authorized four subsequent surveys. The first four surveys were created for specific periods and terminated at their expiration.

\section{FIRST GEOLOGICAL SURVEY.}

The first Survey was known as the Geological and Mineralogical Survey of South Carolina. The work was in charge of Lardner Vanuxem, who served as State geologist of New York and South Carolina. The report of this Survey was published in the newspapers of the State in 1826, and in part in Mills's "Statistics of South Carolina" and in Tuomey's "Report on the geology of South Carolina." This report contained a list of minerals from the Abbeville, Pendleton, Greenville, Spartanburg, and York districts. It was the first geologic report issued under the patronage of any State in the Union. In 1828 Dr. S. G. Morton and Mr. Vanuxem pointed out the existence of "Secondary" (Mesozoic) and Tertiary formations in the State. 
SECOND GEOLOGICAL SURVEY.

Under the second Survey Edmund Ruffin was State geologist. His report, entitled "Report of the commencement and progress of the agricultural survey of South Carolina," was published in 1843. It relates chiefly to the subject of marls as soil stimulants, but also includes a list of invertebrate fossils of the State, and contains numerous analyses of the marls.

\section{THIRD GEOLOGICAL SURVEY.}

Under the third Survey Michael Tuomey was State geologist. His first report, entitled "Report of the geological and agricultural survey of the State of South Carolina," a pamphlet of iv +63 pages, was published in 1844. This was followed, in 1846, by a report to the city council of Charleston, S. C., on artesian wells, and, in 1848, by a report on the geology of South Carolina. The latter report was a volume of 299 pages, with numerous illustrations and a geologic map of the State.

FOURTH GEOLOGICAL SURVEY.

During the fourth Survey (1856-1860) Oscar M. Lieber was State geologist. The publications issued by this Survey consisted of four annual reports to the general assembly, published in the years 1856, 1858,1859 , and 1860. These reports varied in size from 144 to 238 pages and contained several illustrations. Two editions of the first report were issued.

\section{PRESENT SURVEY.}

LEGAL DESIGNATION AND DATE OF ORGANIZATION.

'The present organization is the South Carolina Geological Survey; it was established under an act approved February 21, 1901.

\section{ORGANIZATION.}

There is no governing board. The executive officer is the State geologist. The present incumbent is Earle Sloan, who was appointed April 30, 1901. His present term expires April 30, 1911. The compensation of the State geologist is an annual salary, the amount of which is fixed by statute.

The only office assistant is a stenographer. The field assistants consist of a captain of field camp and laborers. Chemical work is done in the State laboratory, located at Clemson College, and for this work a liberal appropriation is made by the legislature. 
APPROPRIATIONS.

The South Carolina Geological Survey receives an annual appropriation of $\$ 3,400$. There is no law regulating unexpended balances; in fact, the appropriation is usually exceeded.

As construed by the State geologist, expenditures under the law may be directed to economic, stratigraphic, areal, statistical, and paleontologic geology. The expense of chemical work is provided for under the appropriation for the State laboratory and does not come out of the Survey appropriation. A bureau of information is maintained, relating to geology, technology, and many other subjects.

\section{PUBLICATIONS.}

The publications of the Survey comprise (1) a series of annual administrative reports ( 3 to 5 pages), summarizing the scope and general results of investigations, and (2) a series of bulletins in which detailed results of special studies are given. Of the bulletins four have been issued or are in press, one on the clays of the State, one on the geology and mineral resources, one on the marls and other coastal plain formations, and one on the underground waters.

All official publications are printed by the State printer. Copies for officers of the State and members of the legislature are published in accordance with a general statutory provision. Copies of the geologic reports in excess of this number are paid for from the appropriation for the Geological Survey or from the private resources of the State geologist. The size of page, kind of paper, illustrations, and contents of report are left to the State geologist.

The reports are distributed by the State geologist. They are sent to scientific bodies, educational institutions, men of science, and, on application, to persons manifesting active interest in the industrial development of the mineral resources of the State.

PRESENT LINES OF WORK.

Independent investigations.-At present the energies of the Survey are directed chiefly to investigations of the phosphate deposits and peat deposits of the State.

Cooperation with United States Geological Survey.-In cooperation with the Federal Survey an areal and economic survey of the Kings Mountain and Gaffney quadrangles is being made, the results of which will be combined into one geologic folio. The field work for this folio will be completed during the field season of 1911 . These two quadrangles form the key to the geology of a large part of the Piedmont region.

Cooperation with the Federal Survey has also been maintained in the preparation of reports on the geology and underground water 
resources of the coastal plain of South Carolina, which are now in an advanced stage. These will be published as bulletins of the State Survey.

\section{TENNESSEE.}

\section{PREVIOUS SURVEYS.}

State geologic work in Tennessee began in December, 1831. An address delivered before the State legislature on October 19, 1831, by Dr. Gerard Troost, resulted in the passage of a law authorizing the survey, and on December 21, 1831, Dr. Troost was appointed geologist, mineralogist, and assayist of the State. $\mathrm{He}$ held this position until it was abolished by the legislature February 4, 1850. Dr. Troost was also professor of geology and mineralogy in the University of Nashville, from which he received a salary of $\$ 1,000$ a year. He received from the State $\$ 250$ for the first two years and $\$ 500$ annually for succeeding years. Out of his salary he paid traveling and other field expenses. During his term of office Dr. Troost prepared 10 reports. The first two reports do not appear to have been published, and of the last only 75 copies were issued, none of which appear to be extant.

In February, 1854, the legislature again created the office of geologist and mineralogist of the State, and Prof. J. M. Safford was elected to the position. The survey was continued until 1860, when active work was stopped by the civil war. Prof. Safford, however, continued as State geologist by courtesy to the time of his death, a few years ago. In March, 1868, the legislature authorized the preparation of a report and ordered it printed. This report embodied the results of Prof. Safford's work, both as the official State geologist and as a private citizen. During his term of office he published a preliminary geologic report of the State of Tennessee, consisting of 164 pages, and the report authorized in 1868, which was more detailed, consisting of 550 pages.

In 1874 J. B. Killebrew, as secretary to the State Board of Agriculture, prepared a report of 1,193 pages on the resources of Tennessee. This volume includes a general review of the geology and agriculture of the State and of the agricultural and mineral resources, also a detailed review by counties.

Upon the appointment of Prof. L. C. Glenn to the chair of geology in Vanderbilt University, in 1900, he at once began an agitation for a State Geological Survey. His efforts in that direction were supplemented by Prof. C. H. Gordon, on his appointment, in 1906, as professor of geology at the University of Tennessee. The result of the efforts of these geologists, supplemented by a demand from practical mining men and others, was the authorization of the present State Geological Survey by the legislature in 1909. 


\section{PRESENT SURVEY.}

LEGAL DESIGNATION AND DATE OF ORGANIZATION.

The present organization is the Tennessee State Geological Survey: it was established under act of April 30, 1909, which was approved May 1, 1909, but the appropriation did not become available until May 1, 1910, when the Survey began its official existence.

\section{SUMMARY OF LAWS.}

The State Geological Survey is under the direction of a commission known as the State geological commission, composed of the governor (ex officio chairman), the State commissioner of agriculture, the State mine inspector, the president of the University of Tennessee, the chancellor of Vanderbilt University, and the vice chancellor of the University of the South. This commission has general charge of the Survey and the appointment of a State geologist and, on his recommendation, of associate geologists, assistants, and other employees. The State geologist is directed to organize and direct the work; to determine the character, order, and time of publication of the reports; to direct the preparation, printing, and distribution of the reports; to arrange for cooperative work with Federal and State bureaus; to appoint associates, assistants, and employees; to have charge of the necessary field work, office supplies, and equipment; and to supervise the acquisition, care, and disposition of collections, etc. He is also to prepare a report to the general assembly for each meeting.

The State Geological Survey has for its objects and duties the study, mapping, and preparation of reports on the mineral resources, roadmaking materials, structural materials, sands, soils, forests, mineral and artesian waters, drainage of swamps, flow of streams, water powers, and other natural resources. The law provides for the distribution and sale of reports and for the care and final disposition of collections, reports, etc. It authorizes cooperation with other scientific bureaus, makes it lawful to enter and cross lands within the State, and provides an annual appropriation of $\$ 15,000$ for the years 1910 and 1911 for carrying out the provisions of the act.

\section{ORGANIZATION.}

The governing board is the State geological commission, which has already been described under "Summary of laws." The terms of office of the members of the commission depend on their official terms of office or upon the continuance of the Survey. They receive no compensation except necessary expenses in connection with attending the meetings of the commission. 
The title of the executive officer is State geologist, though in other places in the bill he is referred to as the director. The present incumbent is George $\mathrm{H}$. Ashley, who was appointed by the commission March 16, 1910, to serve for two years. The compensation is an annual salary, fixed by the State geological commission.

The clerical force consists of one clerk.

In addition to the State geologist the commission at the same time appointed two associate geologists, Prof. C. H. Gordon, professor of geology at the University of Tennessee, and Prof. L. C. Glenn, of Vanderbilt University. The scientific staff of the Survey also includes two temporary assistant geologists, one of whom is a senior at the University of Tennessee and serves only during the summer vacation. The associate geologists devote to the Survey only such portion of their time as they can spare from their college duties. Their compensation is on a per diem basis.

The associate geologists were not required to submit to an examination; the assistants were also appointed without examination. All appointments are made by the State geological commission on the recommendation of the State geologist.

Cooperation with Federal bureaus is maintained, and it is the purpose of the Survey to devote a large part of the appropriation to cooperative work instead of building up a large independent State Survey.

\section{APPROPRIATIONS.}

The appropriations are made at the biennial sessions of the legislature, presumably for the two succeeding years, though the present, or first, appropriation was not available until a year after the bill was signed by the governor.

Unexpended balances carry over from the first to the second year but lapse at the end of the second fiscal year of the biennium.

The annual appropriation is $\$ 15,000$, for the general objects outlined in the law. This is disbursed in approximately the following proportions:

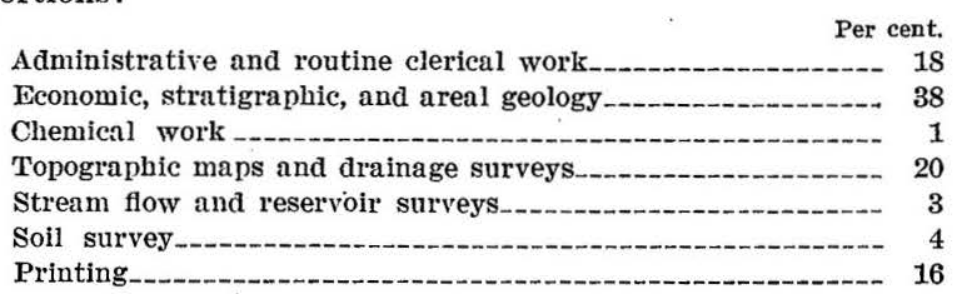

\section{PUBLIGATIONS.}

The publications of the Survey will all be in the form of bulletins. Where a bulletin is composed of several distinct papers, either on the same subject or on related subjects, part of the edition will appear as 
separates, which will be issued as fast as they can be prepared and printed.

Two bulletins and five papers from other bulletins have already been issued.

The size of the edition is 3,000 copies.

Bulletins are to be distributed free to official surveys, public libraries, etc., and on request to interested persons. Five hundred copies of each publication are to be reserved for sale, at the cost of printing. The money derived from sales is to be paid back into the State treasury. Another 500 copies of each publication will be bound in the form of a library edition. In the case of the bulletins which are composed of more than one paper, 500 copies of each separate will be reserved until all the separates belonging to that bulletin have been issued, when they will be bound together into a single volume.

The cost of publications now in press is $\$ 2.65$ to $\$ 3.50$ a page. The expenses of publication are charged to the Survey's appropriation.

The State geologist has full control over the printing, choice of printer, style of report, etc., and also has charge of the distribution of reports.

The mailing list includes State officials, the United States Geological Survey, State surveys, and other bureaus operating along the lines of the Survey's work, the libraries of State universities and to a limited extent those of foreign surveys and national universities, all the regularly constituted libraries of the State, the members of the State legislature and other State officials, independent geologists who may be interested in the subject of the report, and any person who may have made specific request for reports on that subject. A printed card of acknowledgment is inclosed with each report sent out, and the responses will have some influence in determining the distribution of future reports.

PRESENT LINES OF WORK.

\section{INDEPENDENT INVESTIGATIONS.}

The Survey is at present engaged in a general study of the conditions and needs of the State, in a preliminary study of the coal field and the phosphate field of the State, in the preparation of a map of the economic geology of the State, in the preparation of a bibliography of literature relating to the State's resources, and in the formation of a permanent exhibit of the resources and minerals of the State. Preliminary bulletins treating of these subjects will be issued as rapidly as possible. 


\section{COOPERATIVE INVESTIGATIONS.}

United States Geological Survey.-In cooperation with the United States Geological Survey a detailed areal and economic survey of the Pikeville special quadrangle is being made. A preliminary report on the coal resources of this quadrangle will be published as a bulletin of the State Survey, and as soon as the adjoining quadrangle can be surveyed a geologic folio of the two quadrangles will be published by the Federal Survey.

A general study of the oil, and gas development of the State has also been made in cooperation with the Federal Survey, the results being published as Bulletin $2 \mathrm{E}$ of the State Survey.

Cooperation with the United States Geological Survey in topographic work is also maintained. The preliminary control of six 15minute quadrangles in western Tennessee has been completed and the maps are in course of preparation. In cooperation with certain dráinage districts, large-scale detailed topographic maps of some valleys of western Tennessee are also being prepared by the Federal Survey.

United States Department of Agriculture-Cooperation is maintained with several bureaus of the United States Department of Agriculture. With the Drainage Investigations Division of that department a study of the drainage problems of western Tennessee is being made; with the Bureau of Soils a detailed soil survey of the Franklin 15-minute quadrangle is in progress; and with the Office of Public Roads information regarding the roads of the State is being collected.

Other scientific bureaus of the State.-Cooperative arrangements have been made with the State chemist of Tennessee and with the State Agricultural Experiment Station.

\section{VERMONT.}

\section{PREVIOUS SURVEYS.}

The first Geological Survey of Vermont was established in 1845 and was continued for three years. Prof. C. B. Adams was geologist in charge. Three annual reports and a supplementary pamphlet were printed and distributed. Much of the work was pioneer and of a general nature. None of the reports were extensive, but Prof. Adams hoped to issue a larger and more valuable final report. There was, however, never any appropriation for this.

The second Survey was begun in 1857 and continued until 1861. Dr. Edward Hitchcock was in charge of this Survey, and was assisted by his two sons, Edward Hitchcock, jr., and Charles H. Hitchcock, and by Albert D. Hager. The publications of this Survey consisted 
of several reports of progress and pamphlets and a detailed report of considerable value, comprising two quarto volumes, well illustrated, which were published in 1861 .

For several years after the publication of this report Mr. Hager, who appears to have had most to do with its preparation, held the office of State geologist, but there does not appear to have been any appropriation except $\$ 500$ for the care of the State cabinet, which was also to cover expenditures for specimens, etc., needed for the cabinet.

In 1896 the legislature appropriated $\$ 1,500$ annually for two years.

Rev. G. W. Perry was then State geologist. He made no report, and resigned on account of ill health in 1898, when the present State geologist, Prof. G. H. Perkins, was appointed. The present Survey really dates from that time, 1898. Between 1861 and 1898 no active geologic work was done in the State.

PRESENT SURVEY.

LEGAL DESIGNATION AND DATE OF ORGANIZATION.

The present organization is the Geological Survey of Vermont; it was organized in 1898.

SUMMARY OF LAWS AND ORGANIZATION.

The governor biennially appoints a State geologist, the appointment being confirmed by the State senate. The appointee must have competent knowledge of geology. He is to give, on request, advice as to mines, quarries, etc., in the State; to publish biennially · a report of the mineral industries and resources of the State; and to furnish the governor, on demand, information regarding the geology of the State. $\mathrm{He}$ is also the curator of the State cabinet.

There is no governing board. The State geologist is untrammeled in this respect. He has no permanent assistants, but may, within the limit of his appropriation, employ temporary assistants. He is paid a per diem rate and expenses. He is expected to attend the sessions of the legislature, and while in attendance receives the same pay as a member of the State assembly. He holds office until his successor is appointed and confirmed, but is by custom appointed biennially. The present incumbent is Prof. G. H. Perkins, who is also professor of geology in the State University. He has held the office since 1898.

\section{APPROPRIATIONS.}

The amount of the appropriation is $\$ 1,500$ annually. It is a continuing appropriation, or until changed by direct legislative action. In addition there is an annual appropriation of $\$ 500$ for the care and increase of the collections of the State cabinet, of which the State 
geologist is the curator. All appropriations are expended as the State geologist determines, but are subject to the approval of the State auditor. They are devoted to economic, stratigraphic, and paleontologic work.

\section{PUBLICATIONS.}

Under the law the State geologist is required to publish a report biennially. There are no limitations as to the nature or size of the report. The reports usually consist of about 350 pages. The whole cost of publication is paid by the State. The size of the edition is 1,500 copies.

Each State officer and member of the legislature is entitled to a copy of each report, and 100 copies are sent to the State library. The rest of the edition is distributed by the State geologist. Very few copies are sold, chiefly to dealers who ask for it, when a nominal price ( $\$ 1$ to $\$ 1.50)$ is charged. All moneys received from the sale of reports are returned to the State treasury.

The average annual cost of publications during the last ten years, including illustrations, binding, and printing, has been about $\$ 1,000$.

There is a printing commissioner, who places the printing, determines the quality of paper, etc., but the style of the report, the contents, illustrations, size, and most of the details are left to the State geologist.

The mailing list is determined wholly by the State geologist and is made up of libraries in the State and outside of it, of geological surveys of other States, and of any persons or firms interested in the subjects treated in the reports.

PRESENT LINES OF WORK.

The Geological Survey of Vermont has always worked independently of any other survey, because the State legislature has refused to make appropriation for cooperative work. Individually the State geologist has been connected with the United States Geological Survey. The energies of the Survey are directed to economic, stratigraphic, and paleontologic investigations.

\section{VIRGINIA.}

\section{PREVIOUS SURVEYS.}

The first Geological Survey of Virginia was authorized by an act of the general assembly in 1835 and continued through 1841, with Prof. William Barton Rogers, of the University of Virginia, as director. The publications of this Survey were issued as annual reports, entitled "Report of the progress of the Geological Survey of Virginia for the year 1835," etc. Large editions of these reports were printed, but were exhausted many years ago, and they have 
now become extremely rare. Because of frequent requests for these reports, by geologists and others, Mrs. Emma Rogers, widow of Prof. Rogers, assisted by Maj. Jed. Hotchkiss, of Staunton, Va., and Prof. Rogers's brother, Dr. R. E. Rogers, in 1884 reprinted a limited number of copies of a quarto volume, entitled "A reprint of annual reports and other papers on the geology of the Virginias." The volume contains $x v+832$ pages, and is accompanied by a colored geologic map on the scale of 24 miles to the inch and more than 90 geologic sections.

Beginning in January, 1880, and continuing through 1885, a weekly journal was published at Staunton, Va., by Maj. Jed. Hotchkiss as editor, entitled "The Virginias: A mining, industrial, and scientific journal devoted to the development of Virginia and West Virginia." Six complete quarto volumes of about 200 pages each were published. These contain many valuable briefs and abstracts on mineral localities, mines, and mining statistics, and articles on the geology of Virginia and West Virginia.

Beginning in the summer of 1904 and continuing for a period of about two years (1906), a geologic survey of the mineral resources of Virginia, not authorized by the general assembly, was conducted jointly by the State Board of Agriculture and Immigration and the board of visitors of the Virginia Polytechnic Institute, with Prof. Thomas L. Watson as geologist in charge. As the result of this work the following three reports were published and distributed, one of which (Bulletin III) was prepared in cooperation with the United States Geological Survey:

Bulletin I. Lead and zinc deposits of Virginia, by Thomas L. Watson, 1905.

Bulletin II. The clay deposits of the Virginia coastal plain, by Heinrich Ries, with a chapter on the geology of the Virginia coastal plain, by W. B. Clark and B. LeR. Miller, 1906.

Bulletin III. Hydrography of Virginia, by N. C. Grover and R. H. Bolster, 1906.

In 1907 a large illustrated volume entitled "Mineral resources of Virginia " was prepared by Prof. Watson and published by the Virginia Jamestown Commission.

\section{PRESENT SURVEY.}

LEGAL DESIGNATION AND DATE OF ORGANIZATION.

The present organization is the State Geological Survey of Virginia; it was organized in September, 1908, under an act approved February 25, 1908.

\section{SUMMARY OF LAWS.}

The first meeting of the State geological commission was held in the governor's office at Richmond on September 12, 1908, when the commission appointed the director and assistants and approved plans S5645 ${ }^{\circ}-$ Bull. $465-11-10$ 
for beginning the work. The organization of the Survey dates from this meeting, and systematic work was begun immediately thereafter. The objects of the State Geological Survey are briefly set forth in the following act:

Chapter 75. An act to establish a State Geological Survey and to make provision for the preparation and publication of reports and maps to illustrate the natural resources of the State, together with the necessary investigation preparatory thereto.

1. Be it enacted by the General Assembly of Virginia, That there be, and is hereby, created and established at the University of Virginia a bureau, to be known as a State Geological Survey, which shall be under the direction of a commission, to be known as a State Geological commission, composed of the governor (who shall be ex officio chairman of said commission), the president of the University of Virginia, the president of the Virginia Polytechnic Institute, the superintendent of the Virginia Military Institute, and one citizen from the State at large, who shall be appointed by the governor for a period of four years from June 1, 1908. The geological commission shall meet twice each year, once in January and once in June, in the city of Richmond, on the call of the governor, except that the commission may change the time and place of meeting as circumstances may require, and said commission may appoint a clerk to keep a record of its proceedings.

The said commissioners shall serve without compensation, but shall be reimbursed for actual expenses incurred in the performance of their official duties; and the said commissioners shall have general charge of the Survey, and shall appoint as director a geologist of established reputation, who may, with the approval of the commission, appoint such assistants and employees as may be necessary to enable him to carry out successfully and speedily the work of the Survey. The director appointed under the provision of this act, and the assistants and employees appointed by him, shall receive such compensation as may be determined by the commission.

2. The Survey shall have for its objects and duties the following:

(1) An examination of the geological formations of the State, with special reference to their economic products, namely, building stones, coals, ores, clays, soils, cement, materials suitable for use in the construction of roads, mineral and artesian waters, and other mineral substances.

(2) An examination of the road-building materials and the best methods of utilizing the same.

(3) An examination and classification of the soils and study of their adaptability to particular crops.

(4) An examination of the streams and water powers of the State, with special reference to their development for manufacturing enterprises.

(5) An examination of the water supplies of the State, with special reference to the sinking of deep or artesian wells.

(6) An examination of the physical features of the State, with reference to their practical bearing upon the occupation of the people.

(7) The preparation of special geological and economic maps to illustrate the resources of the State.

(8) The preparation of special reports, with necessary illustrations and maps, which shall embrace both a general and detailed description of the geology and natural resources of the State. 
(9) The consideration of such other scientific and economic questions as in the judgment of, the State geological commission shall be deemed of value to the people of the State.

(10) The said commission is hereby authorized to arrange with the Director or the representatives of the United States Geological Survey in regard to cooperation between the said United States Geological Survey and the said State geological commission in topographic, geologic, and hydrographic work in such instances as may be deemed necessary and of advantage to the State, provided that in all cooperative work a sum of money shall be expended by the said United States Geological Survey equivalent to that expended by the said State Geological Survey, and that the said commission may accept or reject the work of the said United States Geological Survey.

3. The commission shall cause to be prepared a report to the legislature before each meeting of the same, showing the progress and condition of the Survey, together with such other information as it may deem necessary and useful or as the legislature may require.

4. The regular and special reports of the Survey, with proper illustrations and maps, shall be printed as the commission may direct, and the reports shall be distributed by the said commission as the interests of the State and of science may demand.

5. All materials collected, after having served the purposes of the Survey, shall be distributed by the director to the educational institutions of the State in such manner as the commission may determine to be of the greatest advantage to the educational interests of the State.

6. The sum of $\$ 10,000$ annually, or so much thereof as may be necessary, is hereby appropriated, out of any funds of the treasury not otherwise appropriated, for the purpose of carrying out the provisions of this act, to be paid out by the treasurer upon the warrant of the auditor of public accounts, which shall be drawn upon the certificate of the chairman of said commission.

Approved, February 25, 1908.

\section{ORGANIZATION.}

The governing body is the State geological commission, which is composed of five members, as stated in the law. The members of the commission serve without compensation, but are reimbursed, out of the appropriation for the Survey, for actual expenses incurred in the performance of their official duties.

The executive officer is called director. The present incumbent is Prof. Thomas Leonard Watson, who was appointed by the State geological commission in September, 1908, for an indefinite period. The director of the Survey is also the professor of geology in the University of Virginia. His time is divided equally between the Survey and the schools of geology in the University. He receives an annual salary, which is fixed by the State geological commission and paid in twelve equal installments.

Assistants include two assistant geologists, one chemist, and one stenographer. These are appointed by the director, with the approval of the State geological commission, and are paid monthly salaries. In addition to the permanent staff of the Survey, four 
college professors are employed on a per diem basis, and since the organization of the Survey several advanced college students have been employed during each summer season.

\section{APPROPRIATIONS.}

Appropriations are biennial. No part of the appropriation is contingent on cooperation. Unexpended balances lapse to the State treasury immediately on the close of the year.

The amount of the appropriation is $\$ 10,000$ annually, of which $\$ 1,750$ is spent in topographic surveys in cooperation with the United States Geological Survey.

\section{PUBLICATIONS.}

The publications of the Survey consist of a series of bulletins, a series of biennial administrative reports, and maps. Of the bulletins five have been issued or are in press. One of these treats of the mineral production of the State for 1908, one of the cement resources of Virginia, one of the titanium and apatite deposits, one of the physiography and geology of the coastal plain of the State, and one of the underground water resources of the coastal plain of the State. Two maps have been issued, one showing the location of mines and quarries, and the other a geologic map of the State on the scale of about 8 miles to the inch.

The size of editions varies from 1,500 to 2,500 , according to the subject and the probable demand.

Publications are mailed to libraries and to interested persons on receipt of postage.

The cost of printing is paid from the Survey appropriation, and the director has full charge of all matters pertaining to the printing. The director also has full control of the distribution of reports.

\section{PRESENT LINES OF WORK.}

Independent investigations.-The independent investigations of the Survey at present include the systematic study and mapping of the copper, gold, and iron deposits and of the building stones, roadbuilding materials, and cement resources of the piedmont and coastal plain provinces of the State, and a report on the areal geology of middle western Virginia.

Cooperation with United States Geological Survey.-In cooperation with the Federal Survey a study has been made of the geology and underground waters of the Virginia coastal plain, the reports of which have been completed and are in press. Also in cooperation with the Federal Survey, four 15-minute quadrangles in the Virgilina copper district were covered by traverse, and a map, on the 
scale of $1: 24,000$, has been prepared of the central part of the area included in these quadrangles.

Cooperation with other State surveys.-In cooperation with the North Carolina Geological Survey a joint study on the Virgilina copper district has been made and a report is now in course of preparation.

\section{WASHINGTON.}

\section{PREVIOUS SURVEY.}

At the first (1890) session of the legislature of the State of Washington two laws were passed providing for a State Geological Survey. One of these acts provided for the creation of the Mining Bureau and defined its powers and duties. The other act created the office of State geologist and prescribed the duties and compensation of that official. The Mining Bureau was composed, ex officio, of the governor, lieutenant governor, and State treasurer. These men, after organization, were to appoint the State geologist, with the advice and consent of the senate. The term of office of the State geologist was to be the same as that of the officers of the Mining Bureau, unless he was sooner removed for cause.

Among the duties of the State geologist were the collection of reliable statistical information concerning the production of minerals of economic value; the making of assays and analyses, for which a stated rate was to be charged; the inspection, at least once a year, of each mining county in the State; and the examination of as many of the mines and mining districts as was practicable. The salary of the State geologist was fixed at $\$ 1,200$ a year, and, in addition, he was to be paid the amount of his actual traveling expenses while in the performance of his duties.

At its session in 1891 the legislature appropriated $\$ 50,000$ for a geologic and mineralogical survey of the State, with maps and reports. In addition, an appropriation was made for the salary of the State geologist and for his traveling expenses. Soon after the adjournment of the legislature the supreme court set aside the appropriation of $\$ 50,000$, so that none of it was spent.

The State geologist from 1890 to 1893 was George A. Bethune. $\mathrm{He}$ issued two annual reports, which were in the main descriptive of the mining districts, the building stones, clays, coal, and other phases of the economic geology of the State

The legislature at its session in 1893 made no provision for geologic work of any kind, and the office of State geologist became vacant and was not again filled until 1901, when a new law was enacted and all the older laws relating to this subject were repealed. 
PRESENT SURVEY.

\author{
LEGAL DESIGNATION AND DATE OF ORGANIZATION.
}

The present organization is entitled State Geological Survey of the State of Washington; it was organized June 5, 1901.

\title{
SUMMARY OF LAWS.
}

\section{The law establishing the Survey is as follows:}

Section 1. There is hereby established a State Geological Survey of the State of Washington, which shall be under the direction of the board of geological survey of the State of Washington, which is hereby established, composed of the governor, the lieutenant governor, the State treasurer, the president of the University of Washington, and the president of the Washington Agricultural College and School of Science, who shall serve without compensation, but shall be reimbursed for actual expenses incurred in the performance of their official duties, and the said board shall have general charge of the survey, and shall appoint as superintendent of the Survey a geologist of established reputation, to be known as the State geologist, and upon his nomination such assistants and employees as the said board may deem necessary, and the said board shall also determine the compensation of all persons employed by the Survey, and may remove them at will.

SEC. 2. The said Survey shall have for its object:

1. An examination of the economic products of the State, viz, the gold, silver, copper, lead, and iron ores, as well as building stones, clays, coal, and all mineral substances of value.

2. An examination and classification of the soils and the study of their adaptability to particular crops.

3. The investigation and report upon water supplies, artesian wells, the water power of the State, gaging the streams, etc., with reference to their application for irrigation and other purposes.

4. An examination and report upon the occurrence of different road-building material.

5. An examination of the physical features of the State with reference to their practical bearing upon the occupations of the people.

6. The preparation of special geological and economic maps to illustrate the resources of the State.

7. The preparation of special reports with necessary illustrations and maps, which shall embrace both the general and detailed description of the geology and natural resources of the State.

8. The consideration of such other kindred scientific and economic questions as in the judgment of the board shall be deemed of value to the people of the State.

SEc. 3. The board shall cause to be prepared a report to the legislature before each regular meeting of the same, showing the progress and condition of the Survey, together with such other information as they may deem necessary and useful or as the legislature may require.

SEC. 4. The regular and special reports of the Survey, with proper illustrations and maps, shall be printed as the board may direct, and the reports shall be distributed or sold by the said board as the interests of the State and of science demand; and all money obtained by the sale of the reports shall be paid into the State treasury. 
SEC. 5. All materials collected, after having served the purpose of the Survey, shall be distributed by the board to the University of Washington, the Washington Agricultural College and School of Science, the normal schools, and the leading high schools of the State in such a manner as to be of the greatest advantage to the educational interests of the State.

SEC. 6. The board of geological survey shall meet for organization within 30 days after the passage of this act. The regular meetings of the board shall be held on the first Wednesday in April and the first Wednesday in November of each year.

SEC. 7. The sum of $\$ 5,000$ annually, or so much thereof as may be necessary, is hereby appropriated out of any funds in the treasury not otherwise appropriated, for the purpose of carrying out the provisions of this act.

SEC. 8. "An act to create a mining bureau and to define its powers and duties, and declaring an emergency," approved February 25, 1890; also "An act to create the office of a State geologist, prescribing his duties and compensation, and making an appropriation for the same, and declaring an emergency," approved February 28,1890 , are hereby repealed.

ORGANIZATION.

The governing board is described in section 1 of the foregoing law. The executive officer of the Survey is known as the State geologist. $\mathrm{He}$ is appointed by the board of geological survey. His tenure of office is at the pleasure of the board. The present State geologist is Henry Landes, who was appointed June 5, 1901. The compensation of the State geologist has been fixed by the board at $\$ 5$ a day, the number of days per annum not to exceed 100. This arrangement was made because the State geologist is also professor of geology in the University of Washington, from which he receives an annual salary. His service as State geologist is supposed to cover only the vacation months of the university.

The subordinates on the Survey are appointed by the board of geological survey, on recommendation of the State geologist. In practice this amounts to the board accepting the recommendations for the positions of chiefs of parties, leaving the State geologist free in his appointments to the minor positions. The clerical work is performed by a stenographer, who is paid by the hour and is employed for one-fourth to one-half of the time. The geologists and other assistants are mainly from the educational institutions of the State where there are departments of geology employing one or more men. Most of the minor positions are filled by advanced students from the departments of geology at the State institutions. The chiefs of parties and principal subordinates in the topographic and water resources work are employees of the United States Geological Survey. In cooperative work the minor employees are usually from the educational institutions of the State. 


\section{APPROPRIATIONS.}

Appropriations for the support of the Survey are made by the legislature at its biennial session. The appropriation made at the last session of the legislature, in 1909, was in part contingent on cooperation with the United States Geological Survey. Unexpended balances lapse to the State treasury at the end of the biennium.

The biennial appropriation made at the session of the legislature in 1909 provided $\$ 55,000$ for the work of the Survey. Of this sum $\$ 30,000$ was for cooperation with the United States Geological Survey in topographic and water resources surveys, conditioned upon an equal sum being spent in the State by the Federal Survey; $\$ 20,000$ was for geologic work, the details of which were not specifically set forth in the bill; and the remaining $\$ 5,000$ was for the purpose of making a report upon the road-building materials of the State. The money has been expended in about the following proportions:

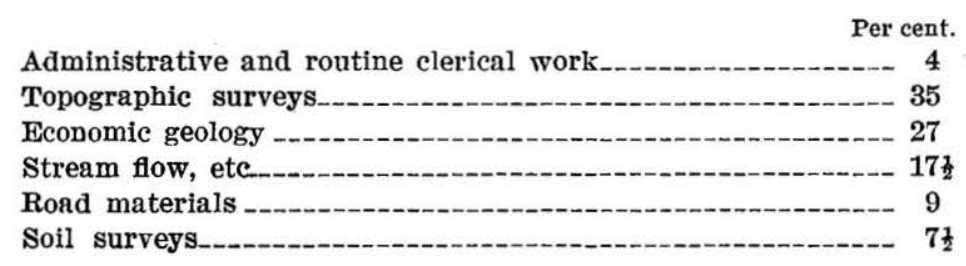

\section{PUBLICATIONS.}

The publications of the Survey consist of a series of bulletins, each one of which is devoted to a particular subject. The size of the edition varies from 1,200 to 2,500. A certain number of each edition are given away as exchanges and to public libraries, but the larger portion are sold at the actual cost of printing. Money received from the sale of reports must be paid to the State treasurer.

The appropriation for printing comes out of the Survey fund.

The board of geological survey, and through it the State geologist, has entire control of the printing of maps and reports so far as style of report, paper, illustrations, contents, etc., are concerned. The law provides, however, that the work must be done by the State printer, whose charges are regulated.

The State law provides that the State librarian shall be the custodian of all State reports. In the matter of Survey publications the State librarian may either distribute the reports from lists furnished by the State geologist or turn the reports over to the State geologist for distribution. 
PRESENT LINES OF WORK.

INDEPENDENT INVESTIGATIONS.

Field work is now in progress on the cement materials of the State, and within a few months a report of the results will be published. Reports on several of the metalliferous mining districts and on the road-building materials of the State are also in course of preparation.

\section{COOPERATIVE INVESTIGATIONS.}

United States Geological Survey.-As provided by the legislature at its last session, $\$ 30,000$ of the Survey's appropriation is dependent on cooperation with the United States Geological Survey. At present $\$ 15,000$ is spent annually by each organization, the money being divided on the basis of two-thirds for topography and one-third for water resources.

A detailed investigation and report on the coal fields of the State is being made in cooperation with the United States Geological Survey, the cost of collecting samples being borne by the United States Survey and the expense of the chemical analyses being borne by the State Survey. Under this agreement about 225 samples have been taken from coal beds in the working mines of the State and analyses made of the chemical properties of the coal.

United States Department of Agriculture.-Cooperation is carried on with the Bureau of Soils of the United States Department of Agriculture, in an economic soil survey of the logged-off lands of the western part of the State. The Federal Bureau supplies about half of the field force and does all of the office work and the printing. The amount of money expended by the State on this soil survey is about $\$ 2,000$ a year.

\section{WEST VIRGINIA.}

\section{PRESENT SURVEY.}

The present State Geological and Economic Survey is the first one establiphed in the State of West Virginia. Aside from the preparation, by Fontaine and Maury, of a "Centennial" volume on West Virginia's resources, in 1876, no official publication concerning the geology of the State had been issued since the annual reports (1835 to 1841) of the late Dr. Wm. B. Rogers, then State geologist, to the legislature of Virginia (which then included West Virginia), showing the progress made by the first Geological Survey of Virginia.

LEGAL DESIGNATION AND DATE OF ORGANIZATION.

The present organization is the West Virginia Geological and Economic Survey; it was organized under law of February 26, 1897, amended in 1903. 


\section{HISTORICAL SKETCH.}

The commission authorized by the act of February 26, 1897, met in December, 1897, and after its organization elected Dr. I. C. White as superintendent of the Survey, with the title of State geologist. Dr. White, from choice, has served the State without salary since 1901. James H. Stewart, director of the West Virginia Agricultural Experiment Station, was elected executive officer, and he has ever since continued to serve in that capacity, without compensation.

With the meager fund at his disposal ( $\$ 3,000$ annually) the State geologist had true meridians properly established and marked in every county of the State, as required by the act, and he also had prepared and published a State map, for the first time showing, by separate colors, the distribution of the several coal series as well as the developed oil and gas pools. In addition, volume 1 (on petroleum and natural gas) of the general series of State reports was prepared and published by the Survey, along with Bulletin 1 (entitled "Bibliography and cartography"). The cost of preparing and publishing the map, volume, and bulletin, having to be paid out of the Survey appropriations, consumed the remaining funds, and as the legislature failed to make any appropriations at its next biennial session, in 1899, geologic work was suspended during 1899 and 1900.

At the next session of the legislature, however, in 1901, biennial appropriations were resumed, and they have been made regularly ever since. A new department of work was inaugurated in 1901the making of a new topographic map of the State, on a scale of 1:62,500, in cooperation with the United States Geological Survey. The State appropriations for this work have been approximately $\$ 15,000$ a year. The appropriations for purely geologic and economic work have grown from year to year with the needs of the Survey, as will be seen from the table given under "Appropriations."

\section{SUMMARY OF LAWS.}

The present Survey of West Virginia had its origin in an act of the legislature passed February 26, 1897, which reads as follows:

An act to establish a State Geological and Economic Survey and to make provision for the preparation and publication of reports and maps to illustrate the natural resources of the State, together with the necessary investigations preparatory thereto.

[Passed February 26, 1897. In effect from passage. Approved February 26, 1897.]

Be it enacted by the Legislature of West Virginia :

1. That there is hereby established a State Geological and Economic Survey, which shall be under the direction of a commission composed of the governor, the treasurer, the president of the West Virginia University, the president of the State Board of Agriculture, and the director of the West Virginia Agricul- 
tural Experiment Station, who shall serve without compensation but shall be reimbursed for actual expenses incurred in the performance of their official duties; and the said commissioners shall have general charge of the Survey, and shall appoint as superintendent of the same a geologist of established reputation, and such assistants and employees as they may deem necessary; and they shall also determine the compensation of all persons employed by the Survey, and may remove them at pleasure.

2. That the Survey shall have for its objects:

First, an examination of the geological formations of the State with especial reference to their economic products, namely, building stones and other constructive minerals and resources; clays, ores, and other mineral substances and fuels, the prevention of their waste, and the utilization of by-products.

Second, an examination and classification of the soils and a study of their adaptability to particular crops.

Third, an examination of the forests and timber lands of the State with reference to the economic utilization of the same and the prevention of their waste.

Fourth, an examination of the physical features of the State with reference to their practical bearing upon the occupations of the people, the industrial development, and the material prosperity of the several sections of the State, having due regard to their varying resources, conditions, and needs.

Fifth, the preparation of special geological and economie maps to illustrate the resources of the State.

Sixth, the preparation of special reports, with necessary illustrations and maps, which shall embrace both a general and detailed description of the geology and natural resources of the State.

Seventh, the consideration of such other scientific and economic questions as in the judgment of the commissioners shall be deemed of value to the people of the State, and the immediate establishing and the proper marking of the true meridian points in the several county seats of the State.

3. That the commissioners shall cause to be prepared a report to the legislature before each meeting of the same, showing the progress and condition of the Survey, together with such other information as they may deem necessary and useful or as the legislature may require.

4. That the regular and special reports of the Survey, with proper illustrations and maps, shall be printed as the commissioners may direct, and that the reports shall be distributed or sold by the said commissioners as the interests of the State, the diffusion of practical information relating to the development of the State, and the advancement of science may demand; and all moneys obtained by the sale of the reports shall be paid into the State treasury.

5. That all materials collected, after having served the purpose of the Survey, shall be distributed by the commissioners to the educational institutions in such manner as to be of the greatest advantage to the educational interests of the State; or if deemed advisable the whole or part of such material shall be put on permanent exhibition.

6. That the sum of $\$ 3,000$ annually, for the years 1897 and 1898 , or so much thereof as may be necessary, is hereby appropriated, out of any funds of the treasury not otherwise appropriated, for the purpose of carrying out the provisions of this act.

Sections 4 and 6 of this act, relating to the disposal of the fund received from the sales of publications, etc., were amended in 1903 so as to read as follows:

SEc. 4. That the regular and special reports of the Survey, with proper illustrations and maps, shall be printed as the commission may direct, and the 
reports shall be distributed or sold by the said commission as the interest of the State, the diffusion of practical information relating to the development of the State, and the advancement of science may demand; and all moneys obtained by the sales of the reports may be used to defray the cost of publication and their distribution to the people, and any balance remaining shall be paid into the treasury.

SEc. 6. That the engineers, surveyors, and other persons employed by and acting for said Survey, and all such persons employed by and acting for the United States Geological Survey, or other department of the United . States Government, having for their object the obtainment and diffusion of practical information relating to the resources and development of the State, and the advancement of science, and for the purpose of carrying out the objects of said State Geological and Economic Survey, shall have the right to enter upon all lands, either public or private, and enter all mines, for the purpose of exploring, surveying, or doing any other matter or thing which may be necessary to effect the said objects, and examine any property, products, or developments relating to the objects of said Survey, within the State, without molestation or arrest and without being liable to the owners thereof, except for actual damages done to the property.

\section{ORGANIZATION.}

The form of organization of the Survey is described under "Summary of laws."

The governing body is the commission, composed of the governor, the State treasurer, the president of the West Virginia University,. the president of the State Board of Agriculture, and the director of the West Virginia Agricultural Experiment Station.

The State geologist and the executive officer of the Survey are appointed by the commission. The present State geologist is Dr. I. C. White, who has served since the organization of the Survey in 1897; since 1901 he has served without compensation. The present executive officer is James H. Stewart, who is also director of the West Virginia Agricultural Experiment Station; he serves without compensation from the Survey. The other active employees of the Survey and their annual salaries are as follows:

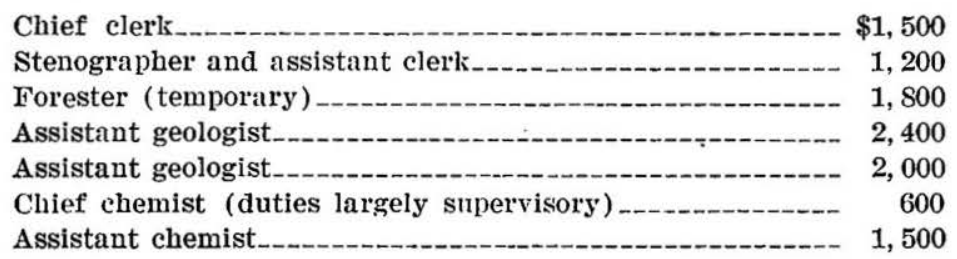

Employees are appointed and their rates of compensation are fixed by the commission, on recommendation of the State geologist. The latter has authority to suspend any of the minor employees for cause.

No college professors are employed, but the chief chemist and his assistant also serve the State Agricultural Experiment Station in 
the same capacity, and the Survey analyses are made in the Experiment Station laboratory, the Survey paying only the cost of chemicals, etc., consumed in its work.

The office of the Survey is in the library of the State University at Morgantown, the university having generously offered accommodations free of charge at the beginning of the Survey's existence. As the chemical laboratory of the West Virginia Agricultural Experiment Station, where all the chemical work of the Survey is done, is under the control of the university regents, the State is not only saved the expense of providing office accommodations for the Survey, but also the cost of duplicating the facilities for chemical work.

\section{APPROPRIATIONS.}

Appropriations are made biennially, and unexpended balances do not lapse into the State treasury if unused at end of fiscal year (September 30).

The cost of administration from the beginning of the Survey to July, 1910, has been $\$ 7,222.36$.

A summary of the appropriations is given below.

Legislative appropriations made to the West Virginia Geological Survey from 1897 to and including 1910.

\begin{tabular}{|c|c|c|c|c|c|}
\hline Year. & $\begin{array}{c}\text { General } \\
\text { purposes. }\end{array}$ & $\begin{array}{l}\text { Coopera- } \\
\text { tive topo- } \\
\text { graphic } \\
\text { surveys. }\end{array}$ & $\begin{array}{l}\text { Salaries } \\
\text { for the } \\
\text { geologic } \\
\text { staff. }\end{array}$ & $\begin{array}{l}\text { Prepara- } \\
\text { tion and } \\
\text { publication } \\
\text { of reports. }\end{array}$ & $\begin{array}{l}\text { Field and } \\
\text { other } \\
\text { expendi- } \\
\text { tures. }\end{array}$ \\
\hline 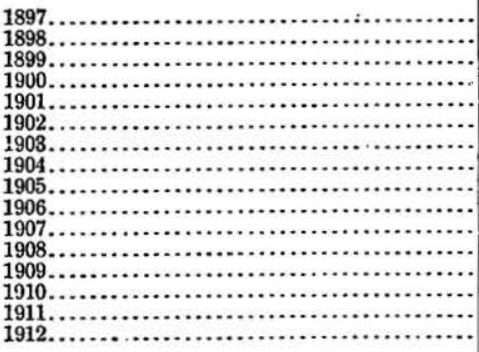 & 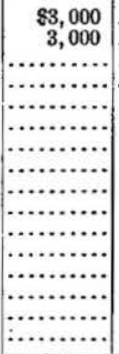 & $\begin{array}{r}\$ 10,000 \\
20,000 \\
15,000 \\
15,000 \\
15,000 \\
15,000 \\
15,000 \\
15,000 \\
12,000 \\
12,000 \\
12,000 \\
12,000\end{array}$ & 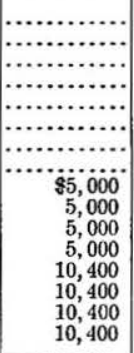 & $\begin{array}{r}\cdots \\
\$ 5,000 \\
2,500 \\
5,500 \\
2,000 \\
5,000 \\
5,000 \\
5,000 \\
5,000 \\
5,000 \\
10,000 \\
5,000 \\
5,000\end{array}$ & $\begin{array}{r} \\
\cdots \\
\cdots \\
32,000 \\
2,000 \\
2,000 \\
2,000 \\
2,000 \\
2,000 \\
2,500 \\
2,500 \\
2,500 \\
2,500\end{array}$ \\
\hline & 6,000 & 168,000 & 61,600 & 60,000 & 22,000 \\
\hline
\end{tabular}

The total appropriations from 1897 to and including 1912 have amounted to $\$ 317,600$.

\section{PUBLICATIONS.}

The publications of the Survey began in 1899 and include (1) a series of volumes devoted to the economic geology of the State, (2) a series of detailed county reports, (3) a series of bulletins on special subjects, and (4) a series of geologic and economic maps. Of the 
economic volumes seven have been issued, two devoted to petroleum and natural gas, two to coal, one to iron ores, building stones, and other minerals, one to clays, limestones, and cements, and one to forestry and wood industries. Of the county reports three have been issued, covering Ohio, Brooke, Hancock, Marshall, Wetzel, Tyler, Pleasants, Wood, and Ritchie counties. Of the bulletins two have been issued, one being a bibliography of all known publications (books and maps) on the State, and the other being devoted to levels and coal analyses. Of the maps, four editions of an economic map showing the coal, oil, gas, and limestone areas of the State have been issued, a total of 17,000 copies, and one edition (5,000 copies) of a map showing railroads and county products.

The editions of the economic volumes have varied from 2,000 to $\tau, 000$ copies. Of the county reports the editions have been 2,500 copies. Of Bulletin 1 the edition was 1,500 copies, and of Bulletin 2 3,500 copies.

The cost of all printing and engraving is paid out of Survey appropriations, and all matters pertaining to the printing are under the control of the commission and the State geologist. The cost of printing has varied as follows: Economic volumes, from $\$ 676$ to $\$ 3,778$; detailed county reports, from $\$ 2,412$ to $\$ 3,369$; economic maps, from $\$ 300$ to $\$ 778$; Bulletin 1, $\$ 149$; Bulletin $2, \$ 1,534$.

The distribution of publications is under the control of the State geologist. Copies are sent to all State officials, and exchanges are made with all State and National surveys and with some distinguished geologists. Those who have given the Survey conspicuous aid are furnished with complimentary copies of all publications desired. To all others the publications are sold at moderate prices. Libraries and teachers are given a discount of 40 per cent from the regular price list, and a large discount is also made to persons who purchase all or several of the Survey publications.

The demand for the publications is constant, and from October 1, 1901, to March 25, 1911, the receipts from their sales, which revert to the Survey, amounted to $\$ 10,209.64$.

PRESENT LINES OF WORK.

INDEPENDENT INVESTIGATIONS.

Of the series of general reports on the economic resources of the State, six volumes have already been published, as described under "Publications." A volume on the forests and plant life of the State is nearly completed, and other volumes of a general nature are planned.

Of the series of county reports, three have been issued and two others are in preparation. For these reports two or three counties are 
grouped together, and the quadrangle base maps are compiled into a single map of the entire area, which is published in three forms-one showing the topography, one showing the geology, and one showing the soils. The soil maps are prepared in cooperation with the United States Bureau of Soils.

\section{COOPERATIVE INVESTIGATIONS.}

United States Geological Survey.-In cooperation with the Federal Survey, topographic mapping of the'State, on a scale of 1:62,500, with 20 -foot and 50 -foot contours, is being prosecuted each season.

United States Bureau of Soils.-In cooperation with the Bureau of Soils of the United States Department of Agriculture a soil survey of each county is being made, the resulting soil maps being published in connection with the series of county reports. Up to the present time soil maps of nine counties have been published and eight other soil maps are in course of preparation.

\section{WISCONSIN.}

\section{PREVIOUS SURVEYS.}

The earliest geologic surveys in Wisconsin were made under the authority of the United States Government by D. D. Owen. In 1839 and 1840 he surveyed the Mineral Point district, and in 1847 the northwestern part of Wisconsin and the adjacent portions of Minnesota and Iowa.

In 1853 Edward Daniels was appointed. State geologist of Wisconsin, but in 1854 he was succeeded by James G. Percival, who held office until his death, May 2, 1856. Each of these men made a brief. report, chiefly on the southwestern portion of the State.

A general geologic survey of the State was not commenced until 1873 , when a survey was ordered by the legislature and I. A. Lapham was appointed State geologist. He continued in that position for two years, when he was succeeded by $\mathrm{O}$. W. Wight, who held the position one year. Lapham died in 1876. In February of that year Dr. T. C. Chamberlin was placed in charge of the survey, and he carried it through to completion. No publications were issued until after Chamberlin's appointment. Among the members of his staff were R. D. Irving, Moses Strong, E. T. Sweet, T. B. Brooks, and I. C. Wooster. The paleontology was in charge of R. P. Whitfield and the natural history in charge of F. H. King. The field work of the survey was completed in 1879 . The report appeared in four octavo volumes, containing about 3,035 pages, with an atlas containing 45 maps. The last volume was published in 1883.

Under the direction of Dr. Chamberlin the geologic survey of the State was made as thorough and complete as possible under the con- 
ditions then existing. It was necessarily much less detailed in the northern part of the State, then largely forest, than in the southern part, but even in the unsettled regions the general problems of the geology were worked out with great accuracy. Few State surveys have more clearly conceived the nature and scope of the general problems of a survey, and still fewer have executed their plans more completely and satisfactorily.

After the publication of this report the organization ceased to exist, and no geologic work was done by the State until 1897. One reason for this is to be found in the exceptional completeness of the Chamberlin survey. If the work had been continued it would necessarily have been along new lines, such as the investigation of special geologic problems and subjects of economic importance. It may also be noted that most of the geologists of the State were at that time becoming engaged in work for the United States Geological Survey, then in process of rapid development. This fact was not without influence in turning them away from local problems to those of a broader nature and concerning larger areas than the State.

The present Survey, therefore, is not a continuance or a direct outgrowth of any preceding organization. It was established partly to complete the general survey of the northern part of the State, partly to investigate special geologic questions of economic or scientific importance, and partly to extend the survey along new lines of study which have been opened in later years.

PRESENT SURVEY.

LEGAL DESIGNATION AND DATE OF ORGANIZATION.

The present organization is entitled the Wisconsin Geological and Natural History Survey; it was organized in 1897.

\section{SUMMARY OF LAWS.}

The law creating the present Survey was passed in the spring of 1897. It provided for (1) the completion of a geologic survey of the State with special reference to economic features; (2) a study of the soils of the State; (3) a study of the plants, especially of the forests, with reference to cultivation and preservation; (4) a study of the animal life of the State, especially the fish; (5) a study of the physical geography and natural history of the State and the publication of results in such form as to serve as manuals for the public schools; and (6) the completion of a topographic map of the State.

ORGANIZATION.

Governing board.-The governing board of the Wisconsin Geological and Natural History Survey is an ex officio body, composed of the governor of the State, the president of the State University, 
the State superintendent of public instruction, the president of the State Fish Commission, and the president of the Wisconsin Academy of Sciences, Arts, and Letters. The State superintendent of public instruction is elected to his office by the people; the president of the State Fish Commission is elected by the members of the commission, who, in turn, are appointed by the governor. The term of office of the members of the board is dependent on their occupancy of the positions, by virtue of which they become members of the board. They receive no compensation except their actual traveling expenses while attending meetings, which are ordinarily held from two to four times a year.

Executive officer.-The executive officer is called superintendent. and director. The present incumbent is Dr. E. A. Birge, who was appointed by the board in 1897 for an indefinite term. The director is dean of the college of letters and science of the University of Wisconsin, and devotes approximately 20 per cent of the year to the work of the Survey. His salary is $\$ 500$ a year; it is fixed by the governing board.

Clerical force.-The clerical force consists of one clerk, who is employed for only a part of the time.

Geologic division.-The geologic division consists of the State geologist, W. O. Hotchkiss, and two other geologists on the permanent staff, all of whom give their full time to the Survey and are not connected with the university in any way. In addition to these permanent employees, the summer field parties are usually made up from advanced students in the University of Wisconsin, who are placed in charge of one of the permanent employees. Members of the geology department of the university staff are frequently employed for working out particular problems, and at the present time four members of the department have such work for the Survey under way or in contemplation.

Water-power division.-The water-power division has done comparatively little work for two years. Prof. Leonard S. Smith, of the college of engineering of the University of Wisconsin, is in charge of this work.

Highway division.-The highway division consists of the State geologist, who is chief of the division, two highway engineers, two bridge engineers, and one clerk. All these men give their full time to the Survey.

Natural-history division.-The natural-history division is in immediate charge of the director, who gives a large part of his summer vacations to the work of this division. The Survey employs one man who gives a small amount of his time to the university, and a 
member of the biology department of the university gives a portion of his time to the work of the Survey. Advanced students in chemistry and biology in the university are employed for summer field work.

Soil division.-The division of soils is in immediate charge of Prof. A. R. Whitson, of the college of agriculture of the University of Wisconsin. Most of the work is done in cooperation with the United States Department of Agriculture and the University of Wisconsin. One chemist and one assistant give full time to this division and numerous other persons give part of their time, chiefly as field assistants and chemists.

Method of appointment and compensation of assistants.-The scientific assistants employed in the divisions of the Survey are nominated by the chiefs of the divisions, subject to approval by the director, and appointed by the board. The clerks are subject to the civil-service law of the State.

There is no specified term of service in any department of the Survey. The special work of the divisions is usually paid for at a per diem rate or at a contract rate for the piece of work specified. Permanent employees of the geologic division are paid from $\$ 75$ to $\$ 250$ a month. Temporary assistants employed during the summer field season comprise both students, who are taken out for the payment of their expenses only, and experienced men, who are paid $\$ 100$ a month.

In the highway division assistant engineers receive from $\$ 50$ to $\$ 200$ a month. In the natural-history division the assistants are paid from $\$ 30$ to $\$ 125$ a month, and in the division of soils from $\$ 30$ to $\$ 100$ a month.

\section{APPROPRIATIONS.}

An appropriation of $\$ 5,000$ annually for two years was made by the act of 1897 creating the Survey. In 1899 the appropriation was increased to $\$ 10,000$ annually for the succeeding two years. In 1901 the appropriation was reduced to $\$ 5,000$ annually and was made a continuing appropriation. In 1903 the annual appropriation was increased to $\$ 10,000$, and it has remained at that figure ever since.

In 1905 a special appropriation of $\$ 2,500$ was granted for the purpose of making a survey of the water powers of the State. In 1907 an additional special appropriation of $\$ 10,000$ annually for two years was made for the purpose of carrying on investigations with regard to road building in the State, extending the survey of the lead and zinc district of Wisconsin, and continuing the water-power survey. In 1909 the special appropriation of $\$ 10,000$ was continued for two more years, and a second special appropriation of $\$ 10,000$ annually 
for two years was made for the prosecution of the soil survey of the State.

Unexpended balances carry to the new year.

The present distribution of the appropriations is about as follows:

$\begin{array}{lr}\text { Administration } & \text { Per cent. } \\ \text { Geology (average four years) } & 2 \\ \text { Natural history (average four years) } & 8 \\ \text { Roads (average three years) } & \\ \text { Soils (one year) } & \\ \text { Publications (average five years) } & \end{array}$

The Survey has done no topographic work except in connection with the geology of parts of the lead and zine district, where careful surveys of about 272 square miles were made with 10 -foot contours.

The cost of administration is hardly more than nominal. The director of the Survey is also a member of the State university. $\mathrm{He}$ spends his vacations in work for the natural-history division of the Survey, and during the year carries on the executive work of the Survey along with that of the university, with the assistance of one clerk for a part of the time. The director receives practically no compensation for the executive work, and the expenses of administration, therefore, can not be regarded as normal for a Survey having this income. Offices and laboratories for all departments are furnished by the University of Wisconsin. Thus almost the entire income of the Survey is devoted to scientific and economic work.

\section{PUBLICATIONS.}

The publications of the Survey are issued as biennial administrative reports, bulletins, and maps. The bulletins are divided into an economic series, of which 13 have been issued; an educational series, of which 2 have been issued; a scientific series, of which 6 have been issued; and road pamphlets, of which 5 have been issued. The maps include 10 hydrographic maps of lakes and lake districts, and a general geologic and road map of the State, which is in press.

The editions vary from 1,200 to 3,000 for the scientific and educational series, 2,500 to 5,000 for the economic series, and 40,000 for the road pamphlets. Publications are distributed for the approximate cost of mailing, until the edition becomes nearly exhausted, when a price is put on the volumes. The average annual income from this source is small. It goes into the State treasury.

The average annual cost of printing reports and accompanying maps for the last five years has been approximately $\$ 5,000$. This is paid out of the State printing fund. 
The printing of reports must be done, according to law, by the State printer, but the choice of paper, the style of report, binding, etc., are left to the Survey. The engraving of maps and illustrations is let to engravers acceptable to the Survey. There is no statutory limitation as to the contents or number of any report.

According to law, a certain number of copies of each report must be sent to each member of the legislature, to several State officers, and to the library of the State Historical Society. Otherwise the distribution of reports is entirely in the hands of the Survey. Its mailing list, which includes numerous universities and scientific societies throughout the world, is kept alive by revision at irregular periods, as the need arises. Exchanges are carried on in cooperation with the University of Wisconsin and the Wisconsin Academy of Sciences, Arts, and Letters.

PRESENT LINES OF WORK.

INDEPENDENT INVESTIGATIONS.

The present main lines of work carried on independently by the Survey consist of (1) an areal survey of the northwestern portion of the State; (2) a geologic survey of the iron district in Florence County; (3) a survey of the peat resources of the State; (4) a new geologic and road map of the State, on the scale of 6 miles to the inch; (5) a survey of the Lake Superior shore, to determine the origin and proper correlation of the Lake Superior sandstone; (6) the work of the highway division, which consists in furnishing technical advice and assistance to town and county officers having charge of road and bridge building; ( 7 ) the compilation of a report on the general geology of the State as an educational bulletin for use in schools; (8) the preparation of an educational bulletin on the relation of the physiography and the industries of the State; and (9) the continuance of the survey of the lead and zinc district of southwestern Wisconsin.

\section{COOPERATIVE INVESTIGATIONS.}

United States Geological Survey.-Informal cooperation with the United States Geological Survey has been maintained in the survey of the lead and zinc district. The survey of the water powers of the State has also been carried on in conjunction with the United States Geological Survey, each organization paying half of the field expenses.

United States Bureau of Fisheries.-The United States Bureau of Fisheries and the State Fish Commission have cooperated to a small extent in a survey of the lakes of Wisconsin, chiefly carried on by the 
State Survey, and in collecting materials for a report on the fishes of the State.

United States Bureau of Soils.-The soil survey begun in 1909 is carried on in conjunction with the Bureau of Soils of the United States Department of Agriculture and the college of agriculture of the University of Wisconsin. The United States Bureau of Soils places as many men in the field as the State Survey, shares the expense of field parties, and contributes much office and laboratory work. The college of agriculture of the University of Wisconsin provides supervision for the survey and quarters for the laboratory work. 



\section{APPENDIX.}

\section{INTERNAL IMPROVEMENT COMMISSION OF ILIINOIS.}

ORIGIN.

The Internal Improvement Commission of Illinois, as it is officially designated, was created by act of the forty-fourth general assembly of Illinois, approved May 16, 1905, and in force July 1. 1905 , with a tenure of two years. This act was the outgrowth of a popular movement favoring the construction of a deep waterway from Lake Michigan to the Gulf of Mexico, and the development of the collateral utilities of such canalization of the Illinois River within the State. There was no antecedent bureau of the State exercising exactly the functions contemplated in this act, though the topographic work of the State Geological Survey embraced some of them in a measure. The Commission was organized February 20, 1906. The original act provided for an existence of only two years, but the forty-fifth general assembly, under an act approved December 24, 1907, extended the life of the Commission four years.

\section{SUMMARY OF LAWS.}

The scope of the work of the Commission is outlined as follows in the act of May 16, 1905:

The duties of this Commission shall be to investigate the various problems associated with a projected deep waterway from Lake Michigan to the Gulf of Mexico, and the reclamation of lands subject to overflow or inundation, the construction of practical and substantial levees, the ascertaining of the acreage of lands now subject to inundations from rivers, the increase from benefits to be derived from this proposed deep waterway and reclamation of lands subject to overflow or inundation, and such other statistics and data.

The following act was approved May 17, 1907:

An act making an appropriation to the Internal Improvement Commission of Illinois, for the purpose of repairing and strengthening the levee at Shawneetown, Ill.

SEction 1. Be it enacted by the people of the State of Illinois, represented in the general assembly, That there is hereby appropriated to the Internal Improvement Commission of Illinois, the sum of $\$ 17,000$, for use in repairing and strengthening the levee at Shawneetown, Ill., so as to protect said city from floods and overflows of the Ohio and Wabash rivers. 
SEc. 2. The auditor of public accounts is hereby authorized and directed to draw his warrant from time-to time upon the State treasurer for the moneys herein appropriated upon proper vouchers, certified by the said Commission and approved by the governor.

\section{ORGANIZATION.}

The governing body is the board of commissioners, composed of three members (Isham Randolph, H. W. Johnson, and T. K. Condit); appointed by the governor. The term of office is indefinite. The members receive no compensation for their services, but are reimbursed for traveling expenses.

The executive officer is the secretary, who is appointed by the commissioners. The present incumbent is Robert Isham Randolph, who was appointed January 1, 1908. The term of office of the secretary is indefinite. He devotes his entire time to the work of the Commission, and is paid an annual salary of $\$ 3,600$. The amount of the salary is fixed by the commissioners.

The assistants employed and their compensations are as follows: Stenographer, $\$ 50$ a month; office boy, $\$ 5$ a week; one junior engineer, $\$ 100$ a month; one field assistant, $\$ 75$ a month; 23 gage readers, $\$ 3$ a month; one draftsman, $\$ 125$ a month.

\section{APPROPRIATIONS.}

Appropriations are made biennially. None are contingent upon cooperation, but a large proportion of the funds are applied in cooperation. The amount of the appropriation varies; for the current biennium it is $\$ 30,000$, no particular objects being specified.

Unexpended balances lapse to the treasury three months after the close of the fiscal year.

Disbursements are about as follows:

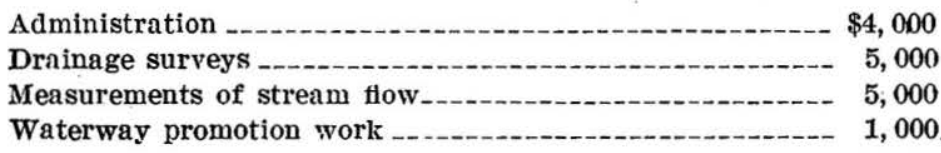

PUBLICATIONS.

Two reports of the Commission have been issued, one in February, 1907, entitled "The Lakes and Gulf waterway," and one in March, 1909, entitled "The Illinois waterway report, with plans and estimates of costs for a waterway from Lockport, Ill., to Utica, Ill., by way of the Des Plaines and Illinois rivers." The edition of each was 5,000 copies. The reports are submitted to the governor, who has them printed. The cost of printing is paid from the governor's appropriation, and the Commission has no control over the printing. 
The reports are distributed free. The mailing list is made up of engineering societies, boards of trade, and civic organizations.

\section{PRESENT LINES OF WORK.}

\section{INDEPENDENT INVESTIGATIONS.}

Independently of the Federal Government, and as a part of the so-called internal improvement plan, the Commission is developing the navigable waterways of the State.

\section{COOPERATIVE INVESTIGATIONS.}

United States Geological Survey.-In cooperation with the United States Geological Survey, 23 gaging stations are maintained for measuring the flow of streams.

Illinois State Geological Survey.-In cooperation with the State Geological Survey, engineering studies are being made of the navigability of Kaskaskia and Big Muddy rivers and drainage of bordering lands. The topographic maps required are prepared by the State Geological Survey in cooperation with the United States Geological Survey.

United States Department of Agriculture.-In cooperation with the United States Department of Agriculture, engineering studies are being made looking to the drainage of swamp and overflowed lands along Little Wabash and Skillet Fork rivers.

\section{TERRITORIAL ENGINEER OF NEW MEXICO.}

The office of Territorial engineer of the Territory of New Mexico was created by the legislature of 1907. The laws governing the office provide for the general supervision of the waters of the Territory and all matters pertaining to irrigation, the making of hydrographic and topographic suryeys of stream systems with reference to the adjudication of water rights, the appropriation of water rights for beneficial uses, and the supervision of the construction of all county bridges costing more than $\$ 1,000$.

\section{ORGANIZATION.}

There is no governing board. The executive officer is the Territorial engineer, who is appointed by the governor for a term of four years, at a salary of $\$ 2,400$ a year. He is also permitted to receive not more than $\$ 2,000$ a year for 'his services as consulting engineer on irrigation projects. The present incumbent is Vernon L. Sullivan, who was appointed in April, 1909.

The Territorial engineer is also a member of the good roads commission, and supervises the work of that commission, and is a mem- 
ber of the Carey Act land board, and serves as engineer in the construction of the projects of that board. The good roads commission and the Carey Act land board are composed of the governor as chairman, the land commissioner as secretary, and the Territorial engineer as engineer. The members of these organizations receive no compensation for their services.

The assistants to the Territorial engineer include five assistant engineers and two clerks. The engineers are college men and do not come under the civil-service rules.

\section{APPROPRIATIONS.}

The annual appropriation for the office of the Territorial engineer is $\$ 8,000$; for hydrographic work, $\$ 3,000$; for good-roads construction, $\$ 50,000$. Balances carry to the new fiscal year.

The annual appropriation for the office of the Territorial engineer includes maintenance and salaries of officers not chargeable to specific appropriations. The appropriation of $\$ 3,500$ is for maintenance of gaging stations and payment of salaries of men connected with stream gaging. For the topographic and hydrographic surveys connected with the adjudication of water rights a fee is charged by the Territorial engineer. This is placed in a special fund, which thus becomes cumulative.

\section{PUBLICATIONS.}

The publications comprise the biennial report for 1907-8 and a bulletin on the economical use of water for irrigation. The results of the cooperative work with the United States Geological Survey are published by the Federal bureau in its series of water-supply papers. The biennial report for 1909-10 and a report on road construction will soon be issued by the Territorial engineer. The size of edition depends on the nature of the report. The publications are sent generally to those who apply for them.

The cost of printing the biennial reports is $\$ 300$ annually, which is paid from the general appropriation of the Territorial engineer. The cost of printing specific reports is $\$ 200$; this is paid from the specific fund.

The Territorial engineer has full control over the printing of reports and maps, being limited only in appropriations. He also has full control over the distribution of reports.

\section{COOPERATIVE INVESTIGATIONS.}

United States Geological Survey.-In cooperation with the United States Geological Survey 41 gaging stations are maintained on streams in the Territory. The results are published by the Federal Survey. 
Good roads commission.-The Territorial engineer is also engineer and supervisor of the work of the good roads commission. It is customary for the counties through which a road is to be built to pay half of the cost of construction. Corporations, towns, and interested persons also contribute to the cost of road building. In this work convict labor is employed as much as possible.

NEW YORK STATE WATER SUPPLY COMMISSION.

\section{PREVIOUS COMMISSIONS.}

The New York State Water Supply Commission, in its work relating to the control and supervision of the water resources of the State, was preceded by the Water Storage Commission of 1902 and the Rivier Improvement Commission of 1904, while some of the work now intrusted to it was previously under the supervision of the State engineer and surveyor and the State geologist.

New York State Water Storage Commission.-After a series of disastrous floods which occurred in the State during the years 1900 and 1901, in response to popular demand, the legislature of 1902 created the New York State Water Storage Commission, and charged it with the duty of investigating the floods and making recommendations regarding the possibility of eliminating the danger from floods by the construction of storage reservoirs. The Commission consisted of nine members, who served without compensation except actual expenses. Four of the number were ex officio members, the attorney general, the State engineer and surveyor, the superintendent of public works, and the forest, fish, and game commissioner. The other members were appointed by the governor and were citizens representing different sections of the State; three of them were civil engineers. This Commission spent a year in investigating the causes and damages of the floods, and in January, 1903, submitted a report, in two volumes, to the legislature. With the presentation of this report the duties of the Water Storage Commission were fulfilled and it was discharged.

River Improvement Commission.-The River Improvement Commission was created by chapter 734 of the laws of 1904 , which became a law on May 14 of that year. This Commission was created "for the regulation of the flow of watercourses in this State in aid of the public health and safety." It was composed of five members, four ex officio "and one commissioner who shall be a civil engineer." The ex officio members were the attorney general, the State engineer and surveyor, the superintendent of public works, and the forest, fish, and game commissioner. The fifth member, the civil engineer commissioner, was appointed by the governor. All the members served without compensation, except the civil engineer commissioner, who re- 
ceived a per diem compensation, fixed by his colleagues, for the actual time devoted to the work of the commission. All the commissioners received their necessary expenses in connection with the work. To this Commission was given the power-

to regulate watercourses, by deepening, widening, and straightening, or by the construction of dams, dikes, or storage reservoirs, but only upon petition praying for the improvement being duly made to it by the parties to be benefited. Any county, city, town, or village located upon any river or watercourse, or any person or persons having riparian rights thereon, may petition the Commission for the improvement of such river or watercourse, and the Commission is charged with the responsibility of determining whether the relief asked for is practicable and is of sufficient importance to the public health and safety to warrant the State in undertaking the work. The entire cost of such improvements must be borne by the counties, towns, cities, villages, and individuals benefited by the regulation of the flow of the stream, unless the Commission shall have determined and reported to the legislature that a portion of the expense is a just and proper charge upon the State. The proportion of the cost which each shall bear, including the State, is determined by the Commission and reported to the legislature, and no such improvement shall be undertaken until after such report has been submitted and the legislature shall have authorized the improvement to be made.

All of the work to be done by the River Improvement Commission was predicated upon the theory of the protection of the public health and safety. Several applications were made under this law, and the proposed improvements were being investigated, when in 1906 the duties and powers of the River Improvement Commission were transferred by law to the State Water Supply Commission.

\section{PRESENT COMMISSION.}

\section{SUMMARY OF IAWS.}

The New York State Water Supply Commission was created by chapter 723 of the laws of 1905 , and was duly organized when the act became a law on June 3 of that year. The Commission is composed of five citizen members, who are appointed by the governor. The principal duty of the Commission as defined in the original act was the supervision over public water supplies. The law provides that no municipal corporation or other civil division of the State, no private water company, and no individual shall have the right to construct a public water-supply system or seek a new source of water supply which involves the acquisition of land until maps, plans, and profiles of the proposed work have been submitted to and approved by the State Water Supply Commission. The Commission was further charged with the duty of investigating all of the then existing watersupply systems in the State and reporting on the sources and purity of their supply, the present and future needs of the community, and the general features of operation of the systems. It was also charged 
with the investigation of the disposal of sewage by municipalities, especially with reference to the possible contamination of present and future public water supplies.

Since the organization of the commission its duties have been enlarged by several amendments to the original act and by new enactments, until at the present time it has supervision over public water supplies for domestic uses, river improvement for the prevention of flood damage and the protection of the public health and safety, and the investigation of the water resources of the State, involving the building of storage reservoirs for the improvement of existing water-power developments and for the creation of new power developments under State ownership and control. The authority for the work last named was conferred by chapter 569 of the laws of 1907, known as the Fuller bill, wherein the State Water Supply Commission was directed " to devise plans for the progressive development of water powers of the State under State control and for the public use and benefit."

The laws under which the Commission is now conducting its operations are article 2, chapter 54, consolidated laws of 1909; chapter 569 of the laws of 1907; and chapters 284 and 464 of the laws of 1909. Article 2 of chapter 54 of the consolidated laws of 1909 is a consolidation of the various laws and amendments theretofore passed creating and governing the River Improvement Commission and the State Water Supply Commission.

\section{ORGANIZATION.}

The State Water Supply Commission consists of five members, appointed by, the governor for a term of five years, except that the original commissioners were appointed, one for five years, one for four years, one for three years, one for two years, and one for one year. Their compensation is fixed by law at $\$ 5,000$ per annum.

The executive officer is the president, Henry H. Persons, the fiveyear member of the original board, who devotes the greater portion of his time to Commission matters. The other officers of the Commission are a secretary and a consulting engineer, both of whom are appointed by the Commission, independently of the civil-service commission.

The secretary has charge of the routine administrative work of the office. He employs two stenographers, one clerk, and one office boy. The consulting engineer is the executive head of the engineering bureau, and his clerical force consists of two stenographers and one office assistant. The clerical force is appointed by the Commission from selections made from certified civil-service lists; the salaries of the clerical force are fixed by law. 
The engineering assistants are appointed by the consulting engineer, from certified civil-service lists, all appointments being subject to approval by the Commission. The engineering field and office corps varies in size from time to time in accordance with the needs of the work. At present it consists of about $40 \mathrm{men}$, who receive the following rates of compensation: One division engineer, $\$ 275$ a month; 2 assistant engineers, $\$ 200$ a month; 4 assistant engineers, $\$ 5$ to $\$ 6$ a day; 4 levelers, $\$ 4.50$ to $\$ 5$ a day; 4 rodmen, $\$ 3.50$ to $\$ 4$ a day; 8 chainmen, $\$ 2.50$ to $\$ 3$ a day; 8 axmen, $\$ 2$ a day; 2 tracers, $\$ 50$ to $\$ 75$ a month; laborers, guides, and camp cooks, as required, $\$ 2$ to $\$ 2.50$ a day.

In 1907 the engineering corps numbered about 50 men, in 1908 about 125 men, and in 1909 about 75 men. The principal work which has engaged the attention of the engineering corps has been the investigation of water storage and possible water-power sites on the principal rivers of the State, and surveys in connection with projects for river improvement.

During the summer months college students are frequently employed in the minor field positions, as many of them are enrolled on the civil-service lists, but college professors are not regularly employed. On several occasions, however, during the last three years, matters relating to the geologic classification of drill-boring samples and the stability of foundations for certain proposed storagereservoir dams have been submitted to professors eminent in their lines, who have furnished reports on the special subjects submitted to them.

The salaries of the commissioners, the secretary, and the consulting engineer are paid monthly; all other salaries are paid semimonthly, as required by a recent act of the legislature.

\section{APPROPRIATIONS.}

Appropriations for conducting the work of the Commission are made annually. The salaries and expenses of the Commission, Secretary, consulting engineer, and the clerical force are provided for in the annual "appropriation bill," and are fixed by law. For the prosecution of investigations of water power and river improvement appropriations are made annually in the "supply bill." These appropriations are based on detailed estimates of the probable needs of the Commission, which are submitted to the legislature on or before January 1 of each year. The Commission is free to subdivide and allot the several appropriations in the supply bill as it may deem wise, provided the money is expended within the scope of the object specified in the supply bill. Unexpended balances, if any, carry over the first year, but are not available after the second year unless reappropriated by the legislature. The fiscal year of the State begins 
October 1. Moneys appropriated in the appropriation bill are available on the 1st day of October next succeeding the passage of the bill, and are for the use of the Commission during the year succeeding. Appropriations made in the supply bill are available for use as soon as the bill becomes a law, and deficiencies of the previous year, if any exist, may be paid out of these moneys.

The appropriation for the year 1910-11 in the appropriation bill is $\$ 41,680$, made up as follows:

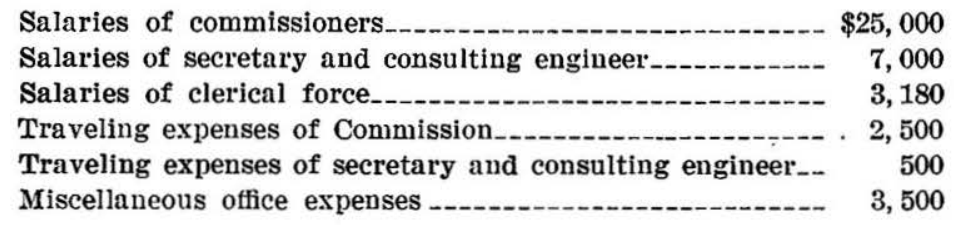

The appropriations in the supply bill for 1910-11 amount to $\$ 70,000$, as follows:

For water supply and river improvement investigations and operations $\$ 20,000$

For continuing water storage and water power investigations

Of the $\$ 20,000$ appropriation the Commission has allotted $\$ 10,000$ to the completion of surveys and studies in connection with projects for river improvement now in hand, and the remainder is held in. reserve to meet the expenses of any applications for river improvement which may be presented during the current year and also for the study of drainage, underground waters, etc.

The $\$ 50,000$ appropriation has been subdivided and allotted by the Commission as follows:

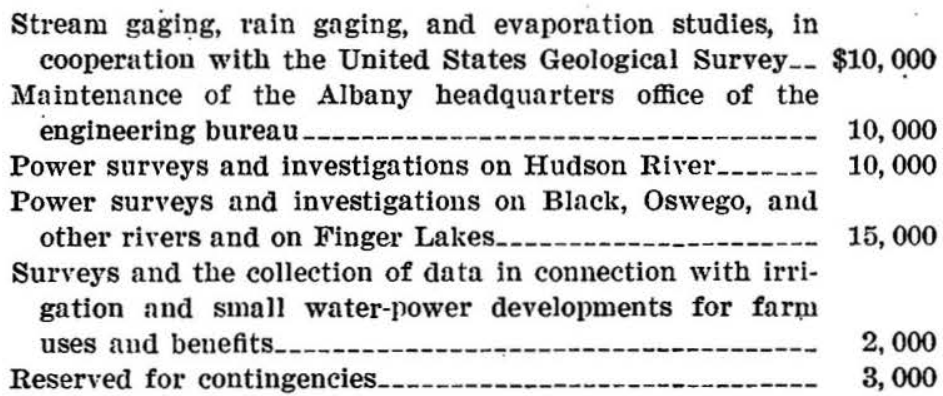

Between July 1, 1907, and July 1, 1910, the Commission expended $\$ 7,950$ for stream gaging in cooperation with the United States Geological Survey, most of the sum being expended in the Adirondack Mountain region and on Genesee, Raquette, and Hudson Rivers. During the same period $\$ 1,055$ was expended for rainfall and evaporation observations in cooperation with the United States Weather Bureau. 
The New York State Water Supply Commission has issued five annual reports, one progress report, and one bulletin. The annual reports set forth the work accomplished by the Commission, and have varied in size from 200 to 800 pages, with accompanying illustrations from photographs, maps, plans, and charts. The progress report was issued in 1908 and pertained to the water-power investigations. The bulletin was issued in 1909 for free distribution at the State fair, and consisted of a concise account of the scope and accomplishments of the Commission since its organization.

Of the regular reports, 2,500 copies are issued and distributed each year. The cost of distribution is borne by the Commission, but the printing is done by the State printer, under the direction of the State printing board, and the cost is charged to the State printing account and does not come out of the appropriations for the Commission. If extra copies of the report over and above the number specified by law $(2,500)$ are desired, the Commission must bear the expense of printing the additional copies. The Commission has control over the style of its reports, the paper used, the number and kind of illustrations, and the contents.

About 500 copies of every report go to the members of the legislature and the State officers for their use and distribution. The remainder are distributed by the Commission. Copies are promptly sent to public libraries, colleges, universities, and engineering societies throughout the State, without awaiting their requests, also to persons who have requested that they be supplied with a copy of each report issued. Thereafter reports are sent to anyone making application for them. A receipt card is inclosed with each report sent out, and the receiver is asked to sign and return it.

\section{PRESENT LINES OF WORK.}

Independent investigations.-The main lines of work in which the Commission is engaged have been outlined under "Summary of laws."

Cooperation with United States Geological Survey and United States Weather Bureau.-In connection with the investigations of the Commission reliable information regarding stream flow, rainfall, and evaporation is of the utmost importance, and to obtain this information the Commission in 1907 entered into cooperative agreements with the United States Geological Survey and the United States Weather Bureau.

Under the cooperative agreement with the United States Geological Survey stream gaging has been conducted according to the standard methods of the Survey, under the supervision of one of its 
district engineers, whose headquarters have been at Albany since 1909. Heretofore 12 gaging stations have been maintained, but a number of new ones will be established during the ensuing year.

In cooperation with the United States Weather Bureau eight rainfall observation stations have been maintained since 1907 . These stations are equipped with standard United States Weather Bureau rain gages, maximum and minimum thermometers, and thermometer shelters. The work is under the supervision of the section director, whose headquarters are at Ithaca, N. Y. All the stations are in the Adirondack Mountains, at points from which no previous records were available. In addition to the maintenance of the foregoing stations comparative tests of four types of rain gages have been conducted through the summer seasons at the Weather Bureau stations in Ithaca. The gages employed in these tests are the De Witt conical, the Fuertes, the Smithsonian, and the United States Weather Bureau standard, two gages of each type being used. These comparative tests are made for the purpose of determining, if possible, the accuracy of older types of gages as compared with present-day standards, with a view to coordinating old records with those taken to-day under more scientific methods.

All of the existing rainfall stations will be maintained during the coming year, and 14 new stations will be established and equipped with standard gages, thermometers, etc. The new stations will be established in the basins of upper Hudson, Raquette, Oswegatchie, and Oswego Rivers.

Arrangements have recently been consummated whereby the rainfall and evaporation investigations, in addition to the stream gaging, will be carried on in cooperation with the United States Geological Survey, through its local district engineer.

Other cooperative work.-No interstate cooperative work is maintained by the New York State Water Supply Commission. In 1909, however, upon its own initiative the commission met in conference with similar commissions from the States of Pennsylvania and New Jersey, with a view to cooperating in the investigation of interstate and boundary line streams, but no definite system of cooperation has been undertaken.

There is no systematic cooperation with other scientific bureaus of the State, but wherever the duties of the State Water Supply Commission unite with or overlap the duties or jurisdiction of the department of the forest, fish and game commissioner, the department of State engineer and surveyor, the State department of health, or the public-service commission, there is a cordial interchange of data and assistance. 



Lithomount

Pamphlet

Binders

Gaylord Bros. Inc.

Makers

Syracuse, N. Y. 
